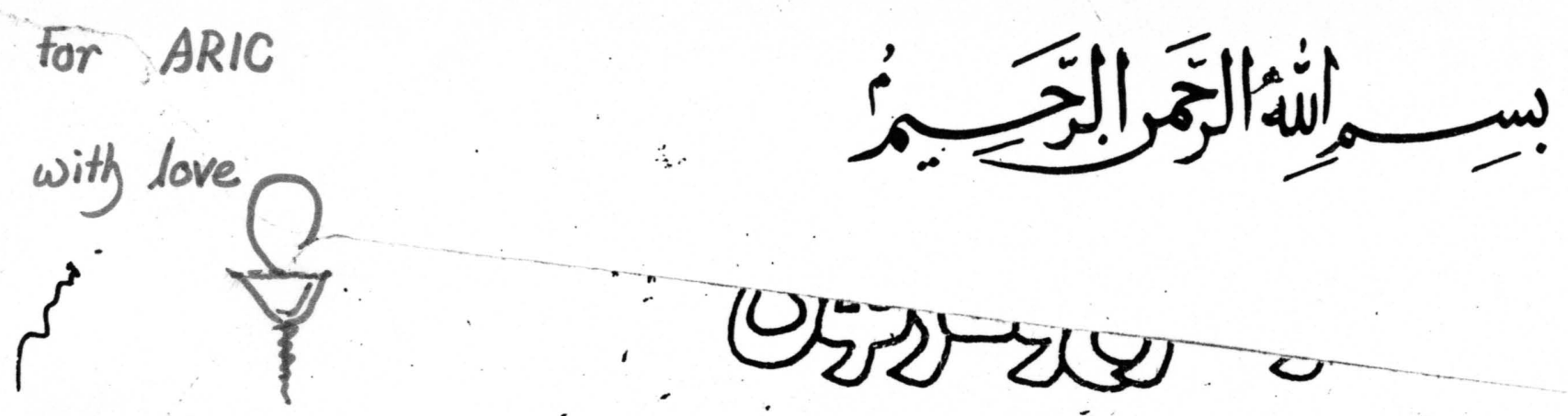

Saboor Siasana

Islamabad, 18.05.2000..

\title{
CAPTOONS FROM
}

$$
\begin{aligned}
& \text { CHlA: }
\end{aligned}
$$

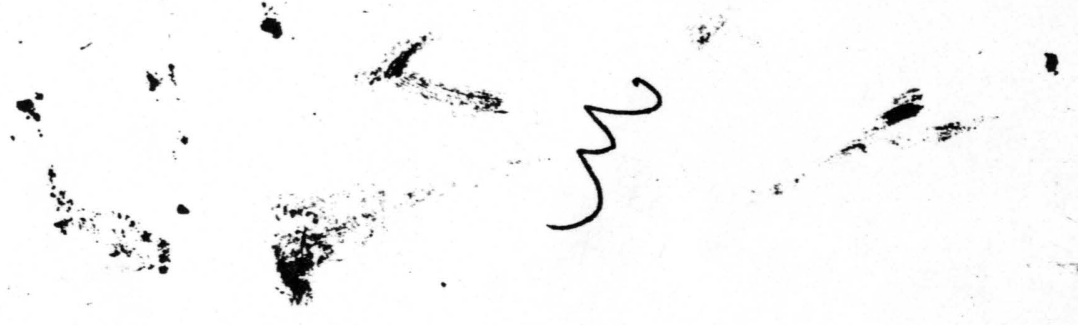

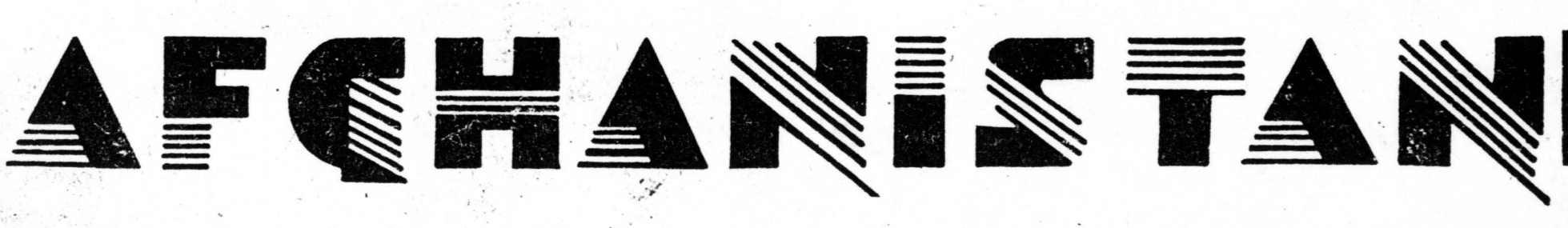



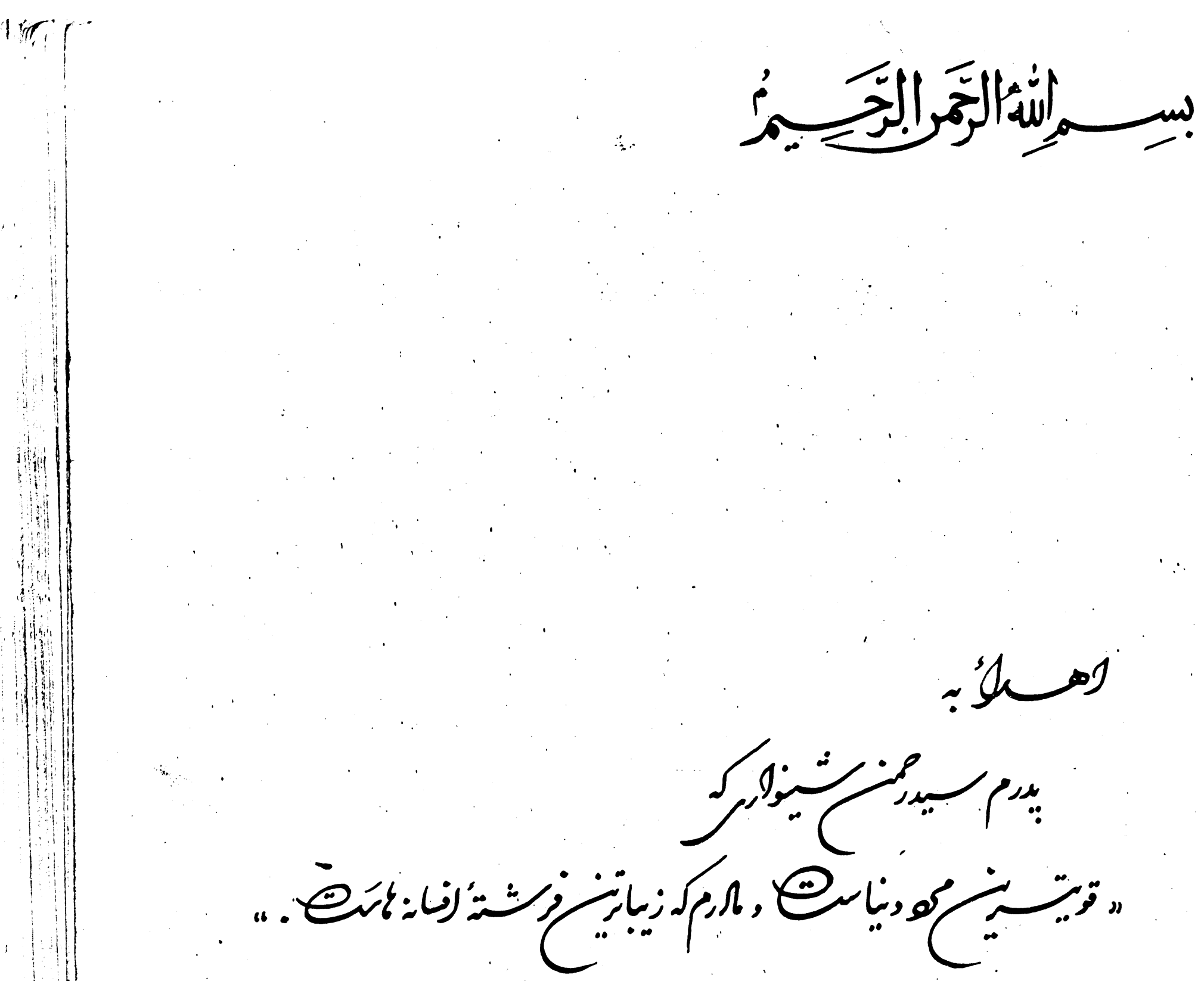

Gifted to my father, "who is the mightiest man the world over and to my mother, who is the fairy of the legends." 


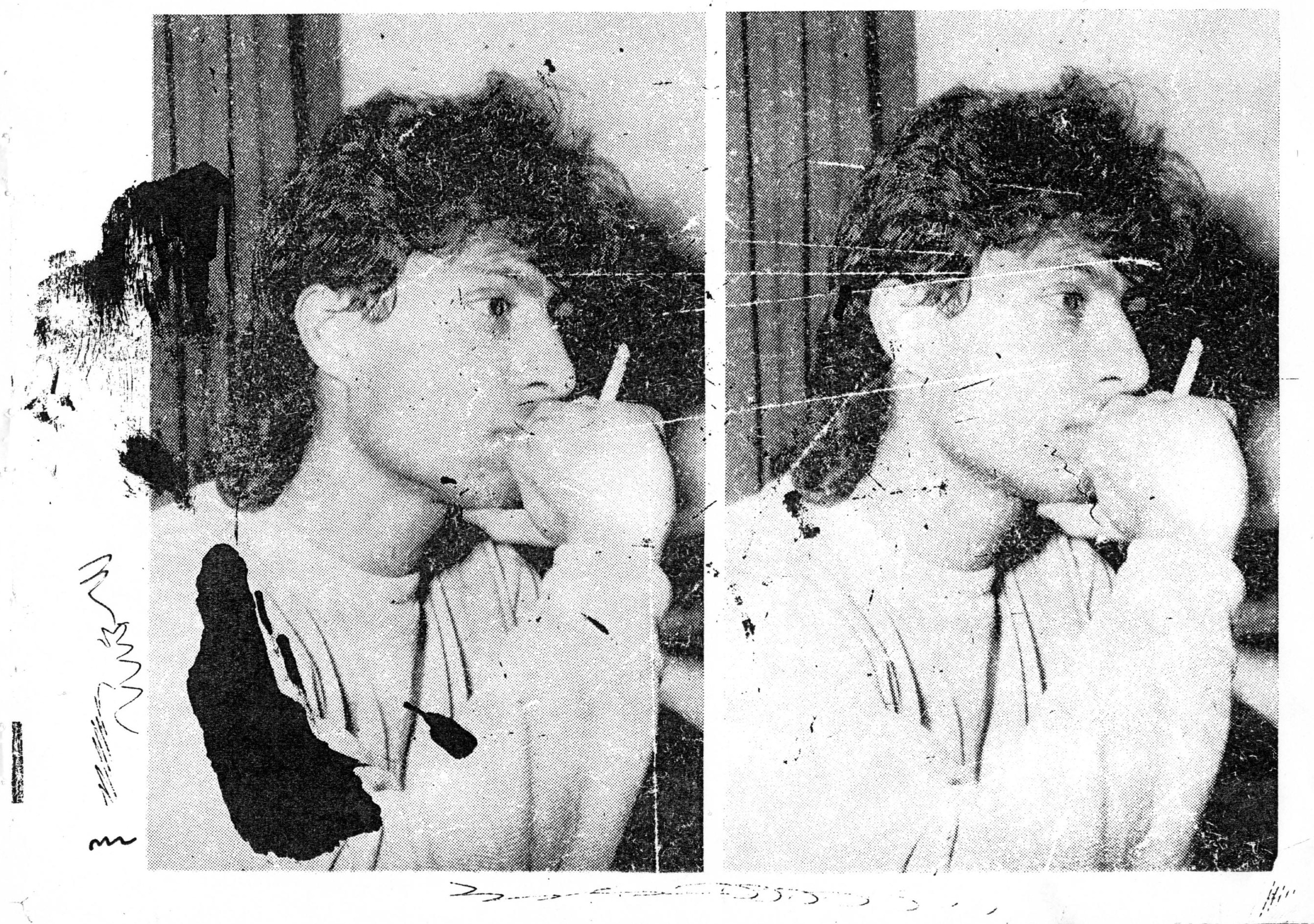




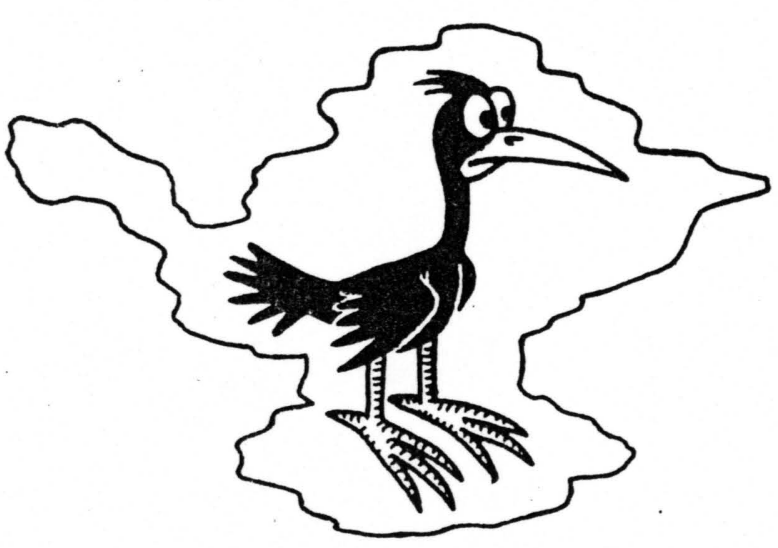

Years back in a snowy night, I was born in Kabul city in 1961. Graduating from Istiqlal lycee, I atteded Faculty of Law. Since the very childhood, I have been fascinated by the world of painting. In th1s world of dream and passion, I have been living with my childish feolings and fantasies and have sought the answer to the questions of my life, sentiments and passions in this impressive orld of cartoons.

Here, I invite you to a short visit to this charning world and thus to my country. Hope, gou are with me not only in this short trip, but for ever and a part of my world.

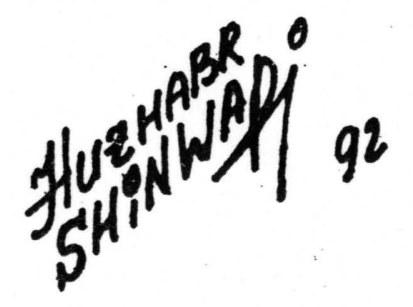

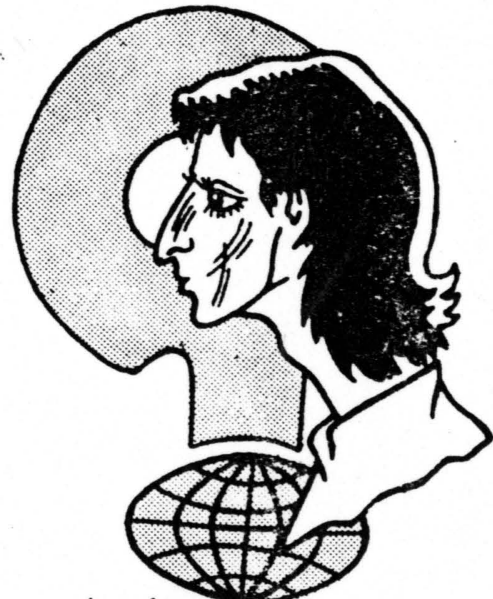
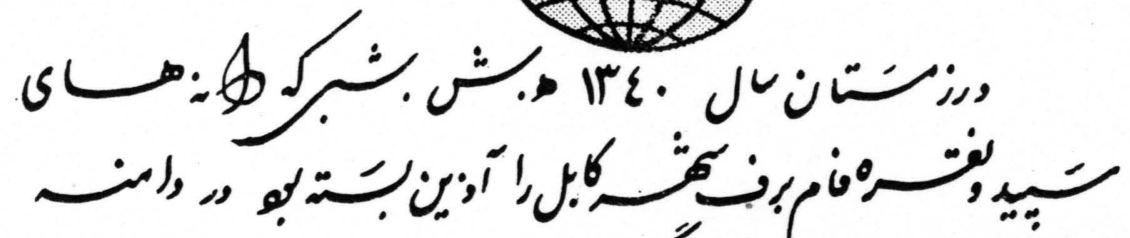

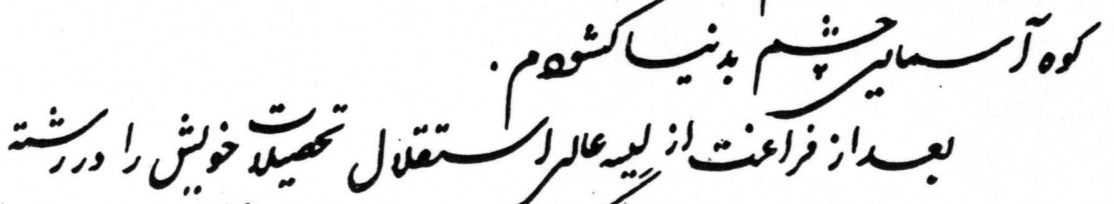

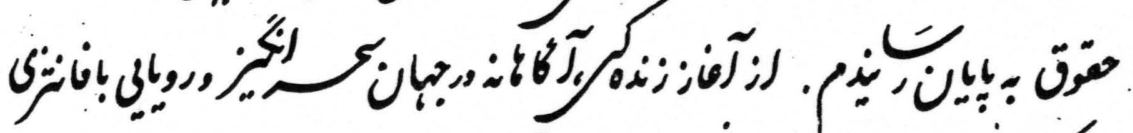

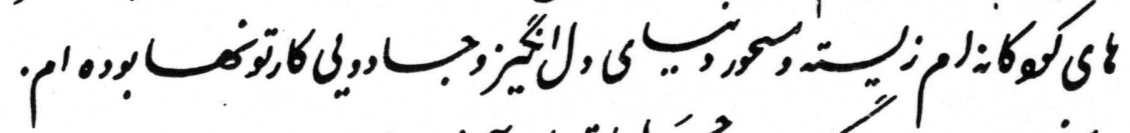

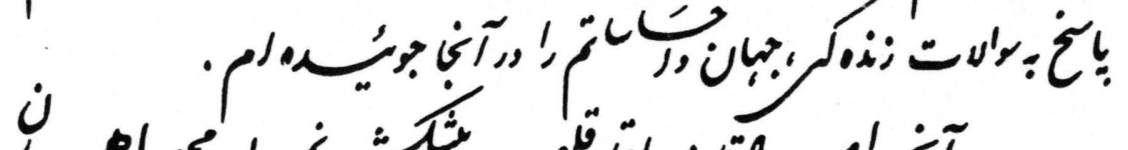

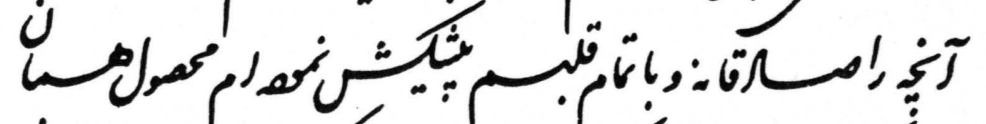

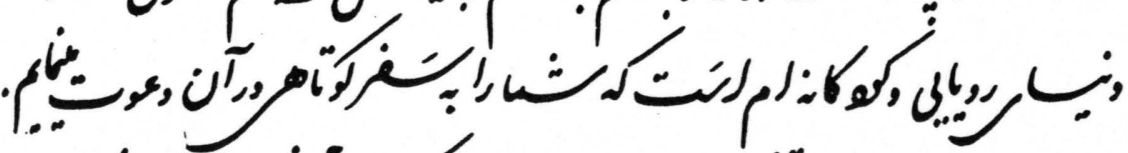

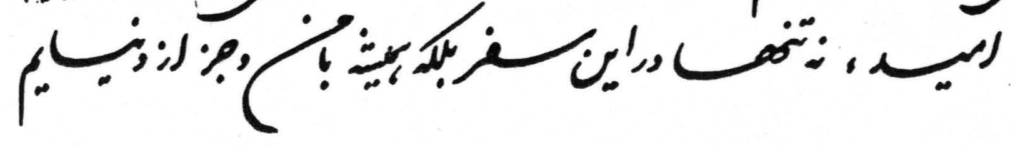


ל nw 5 है

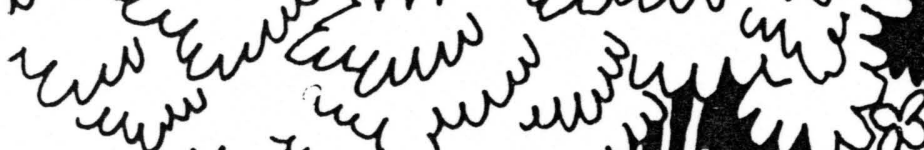
my

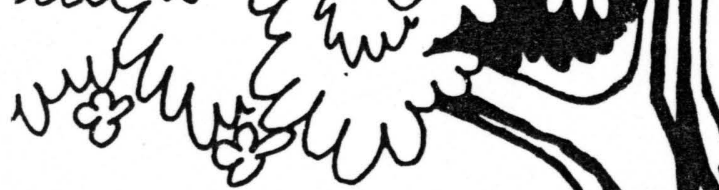
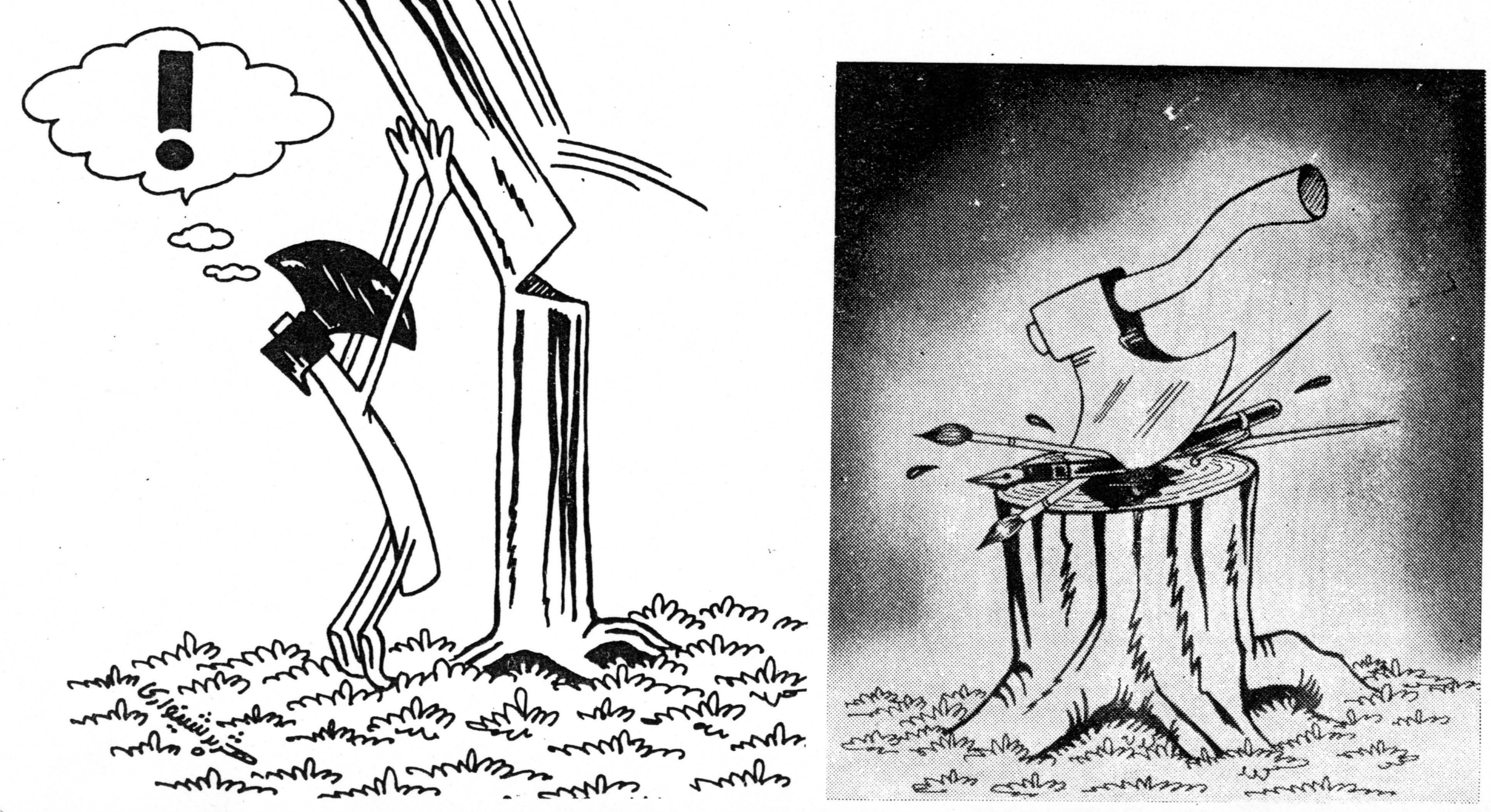


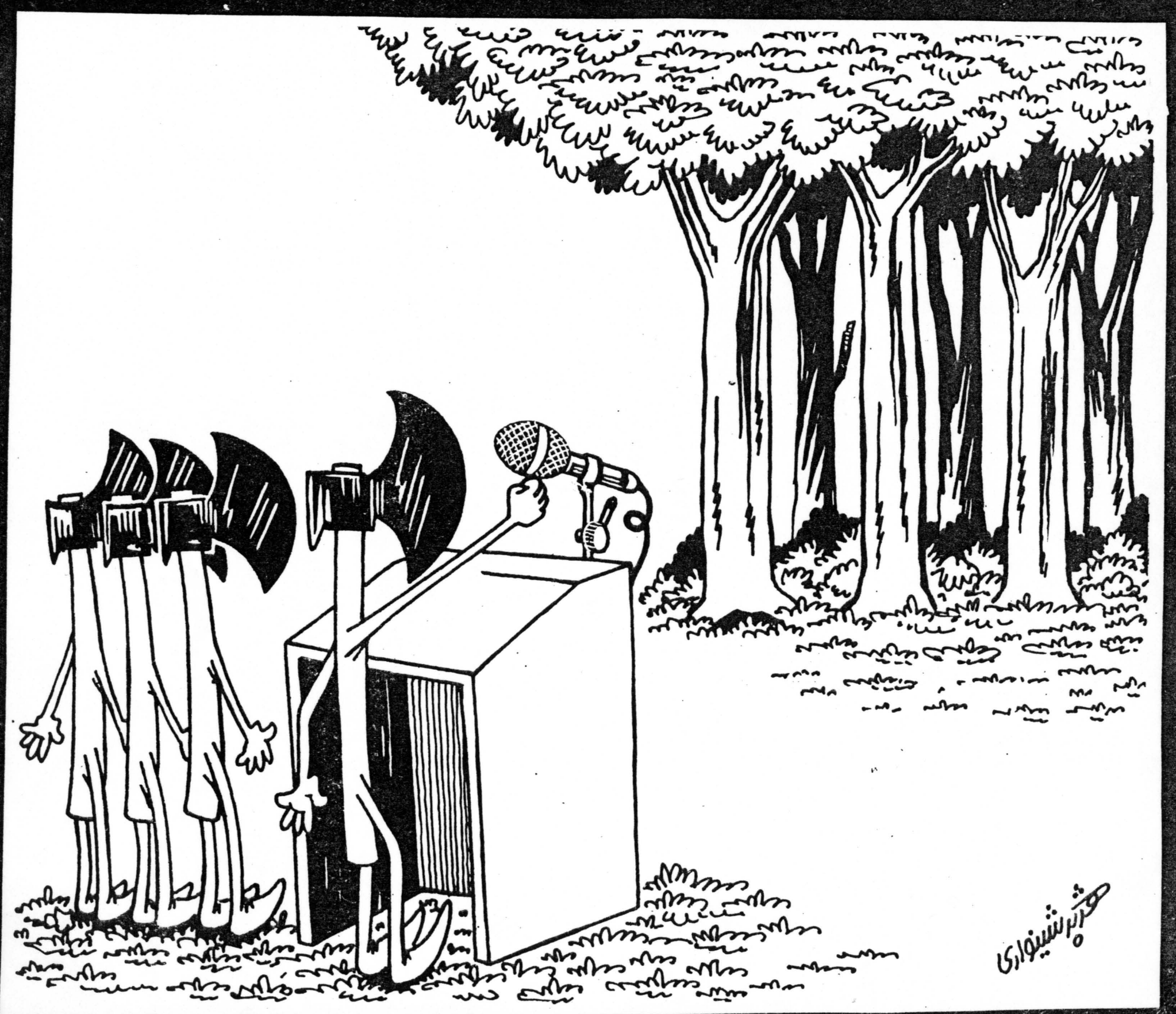




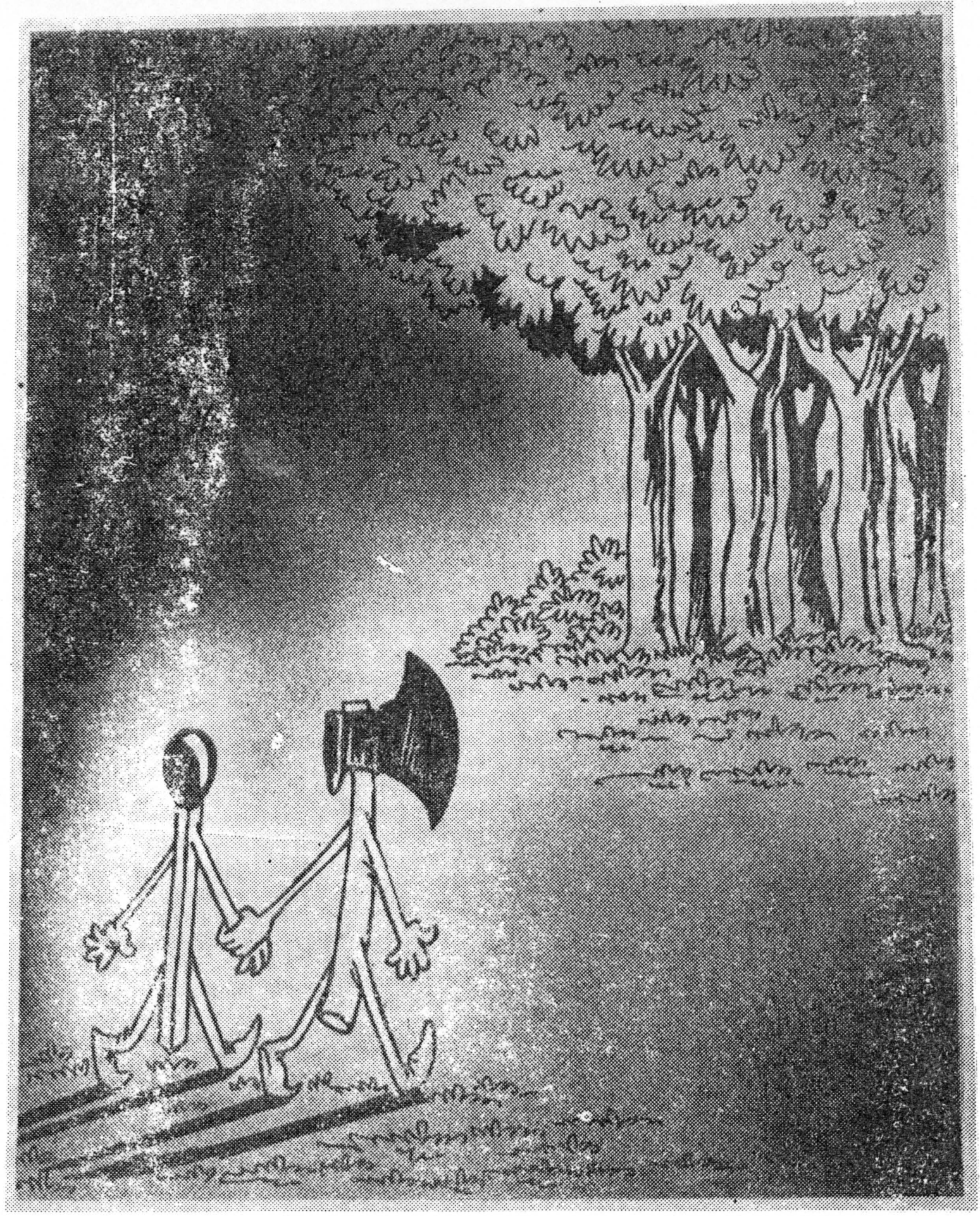




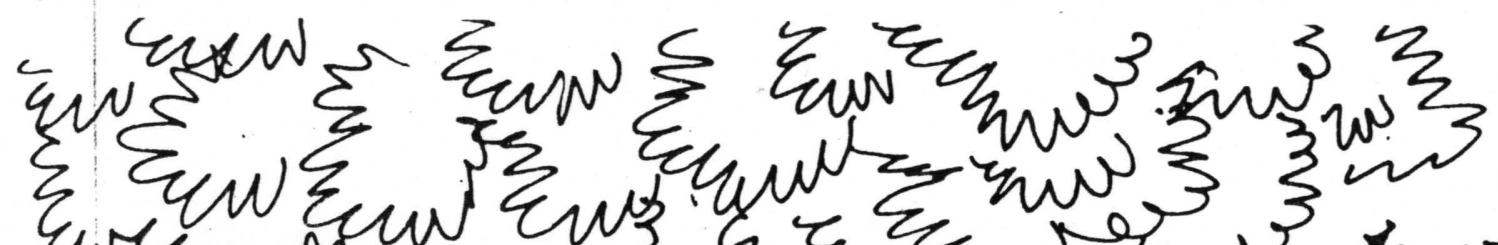

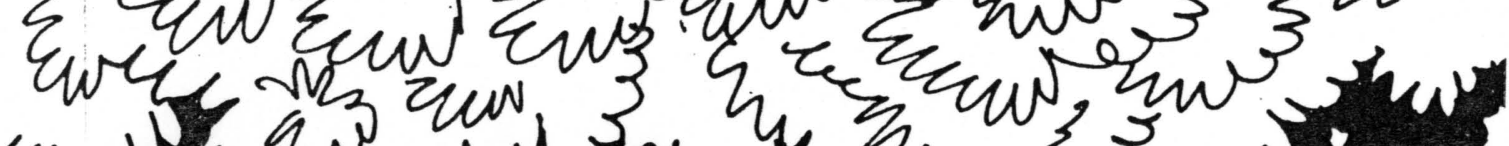

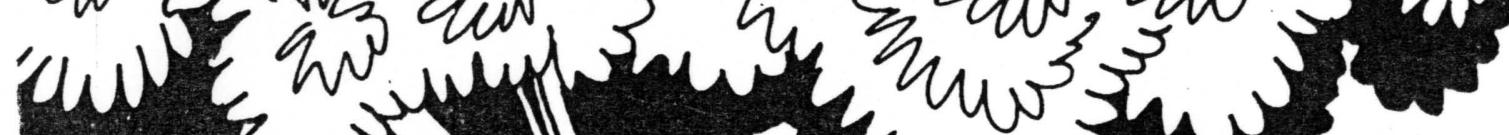

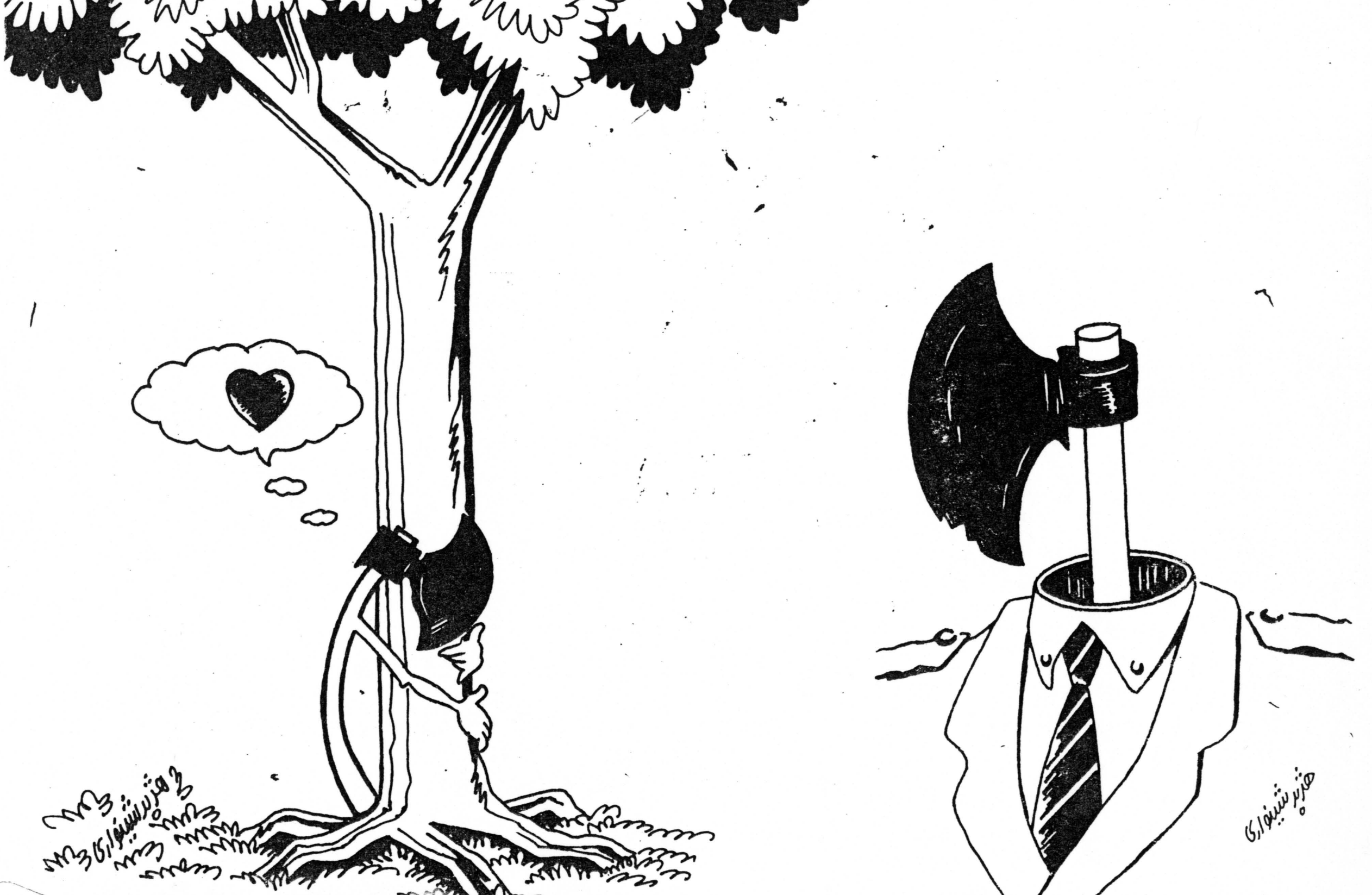




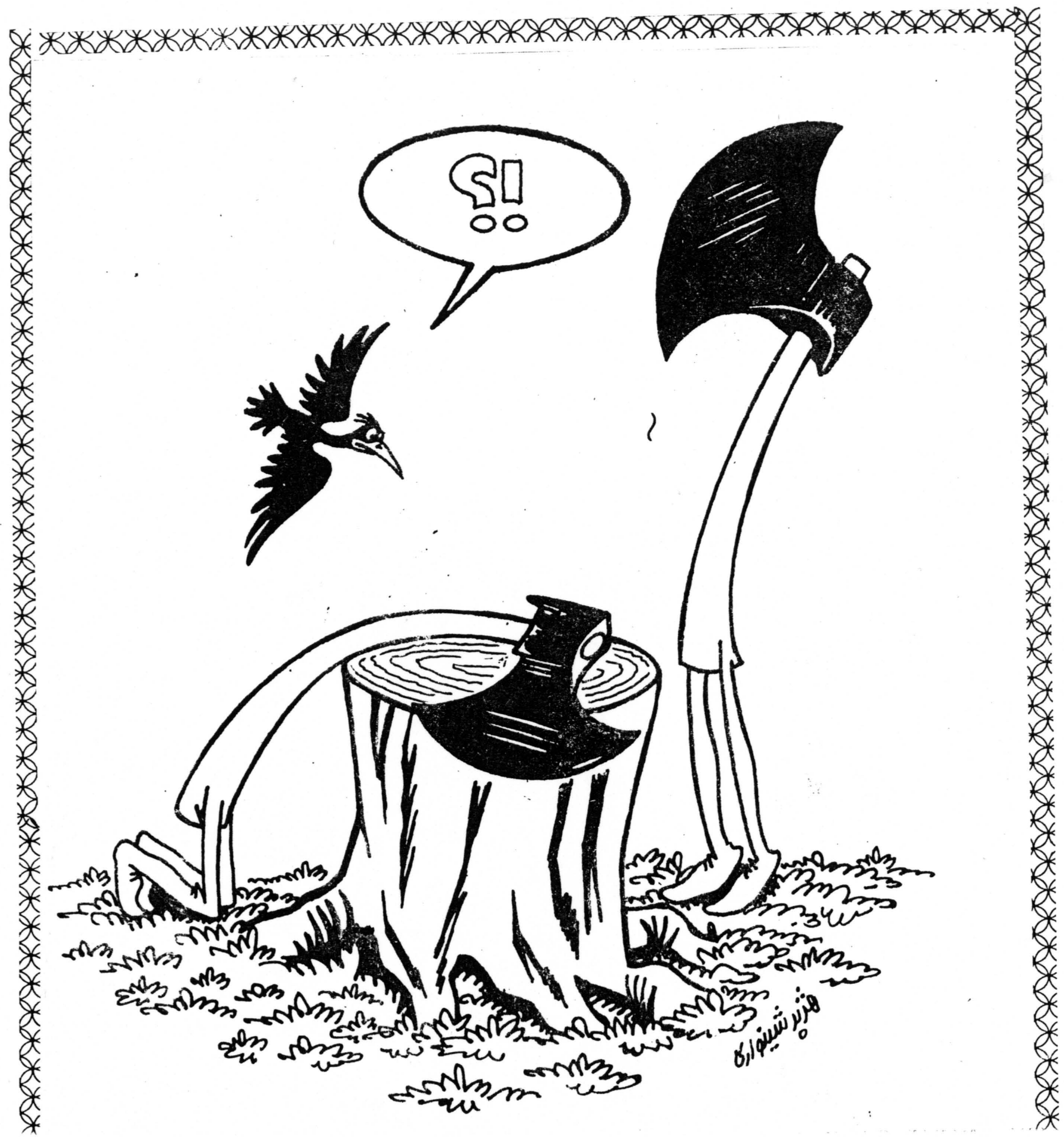




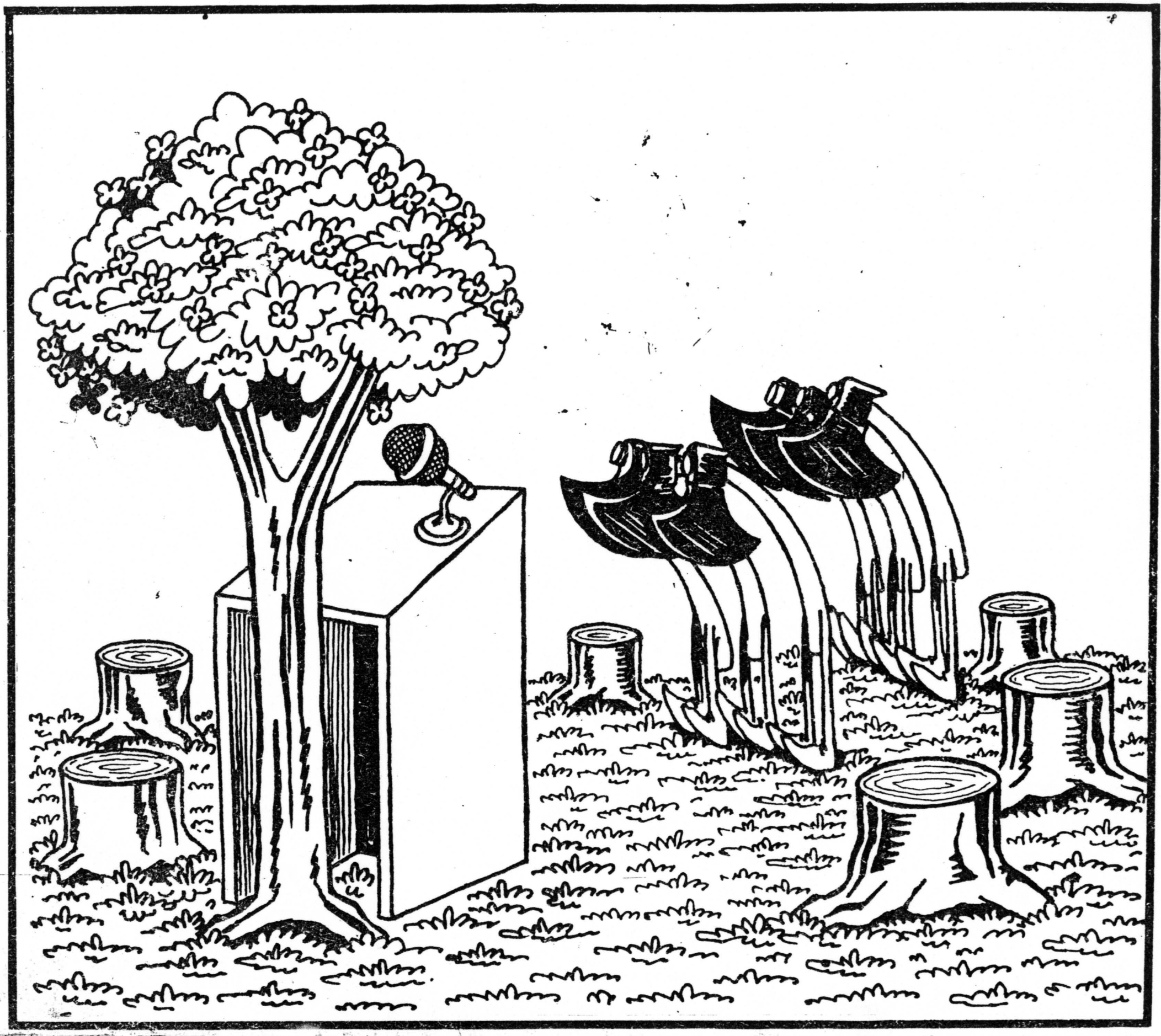




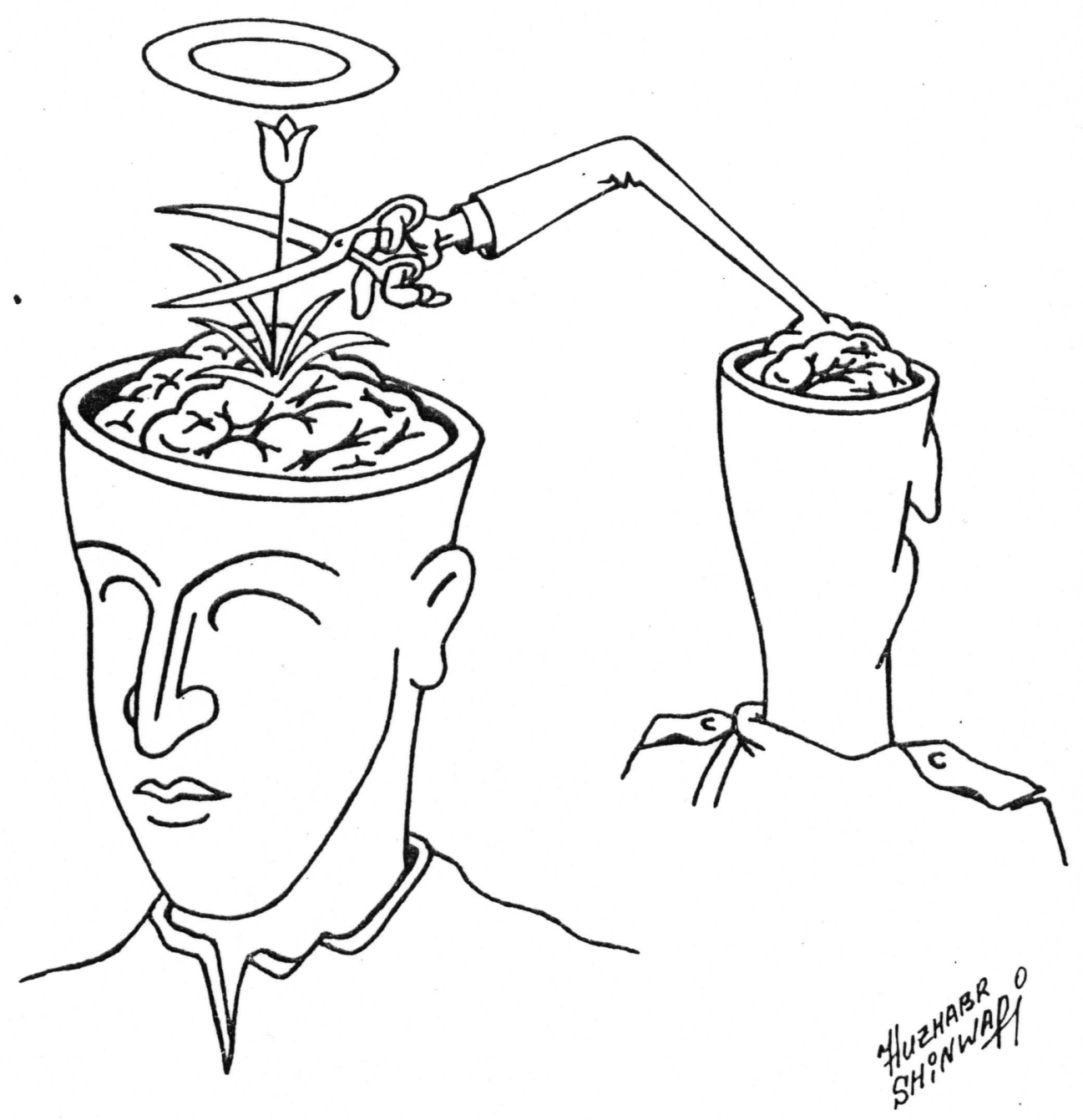



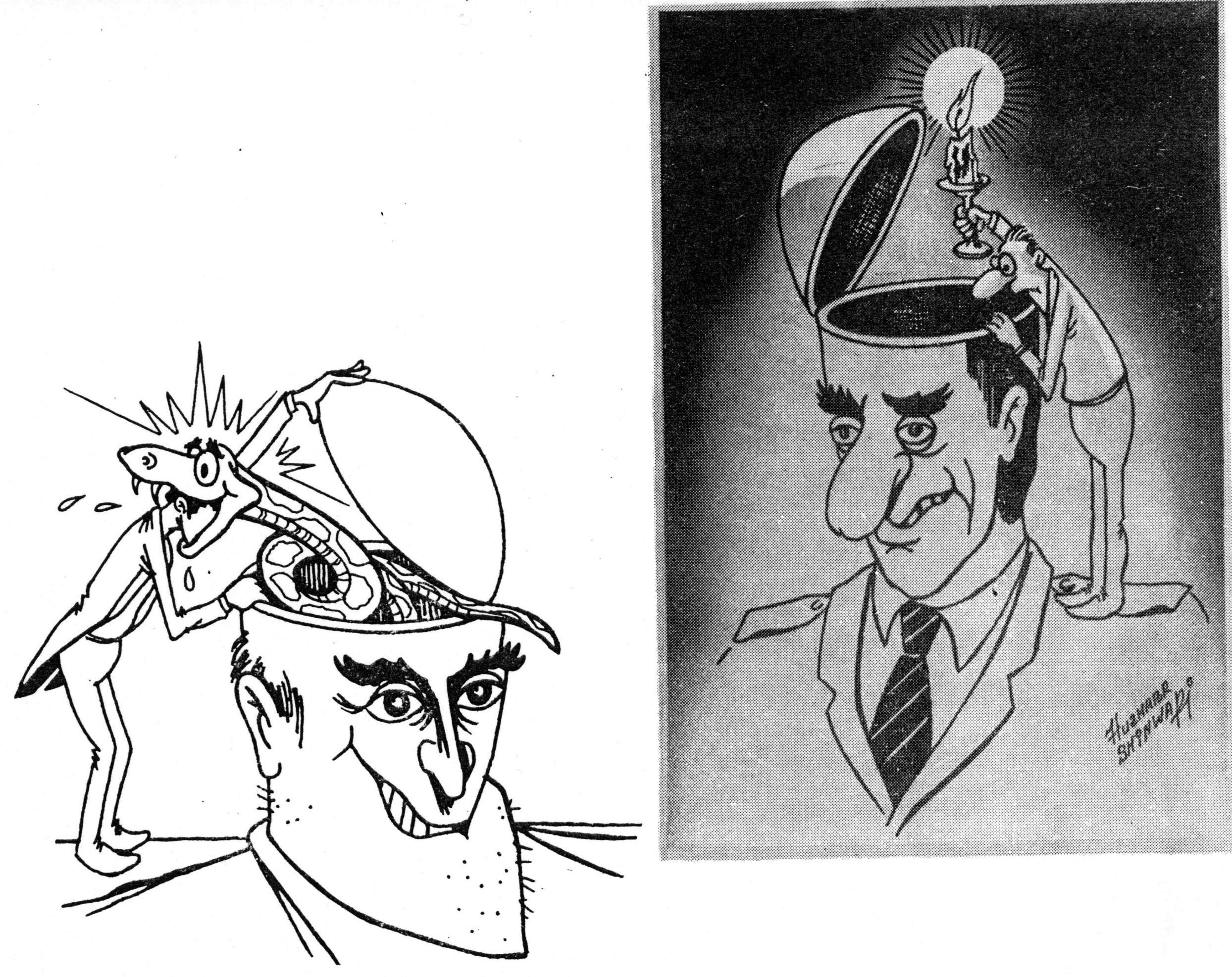

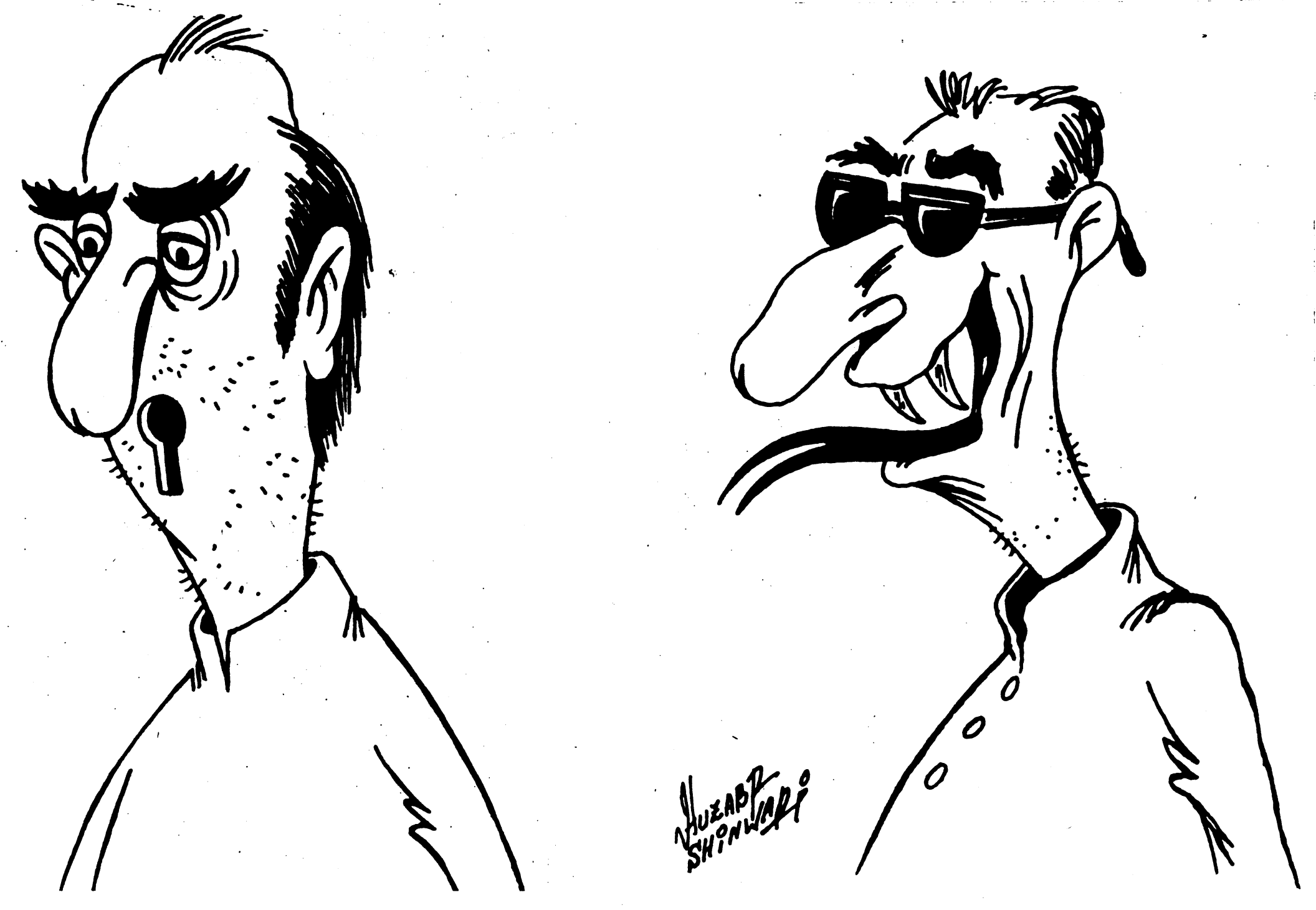


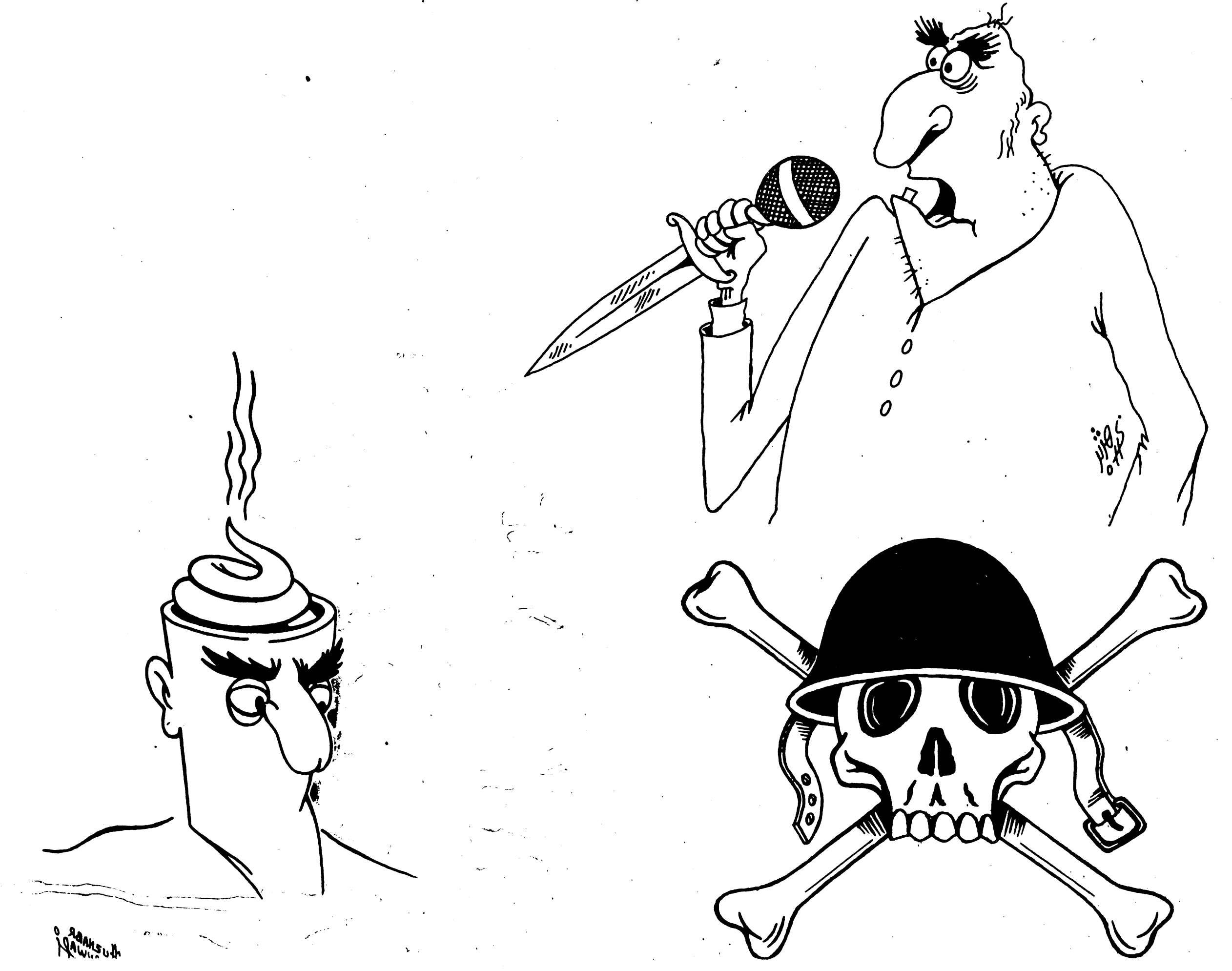



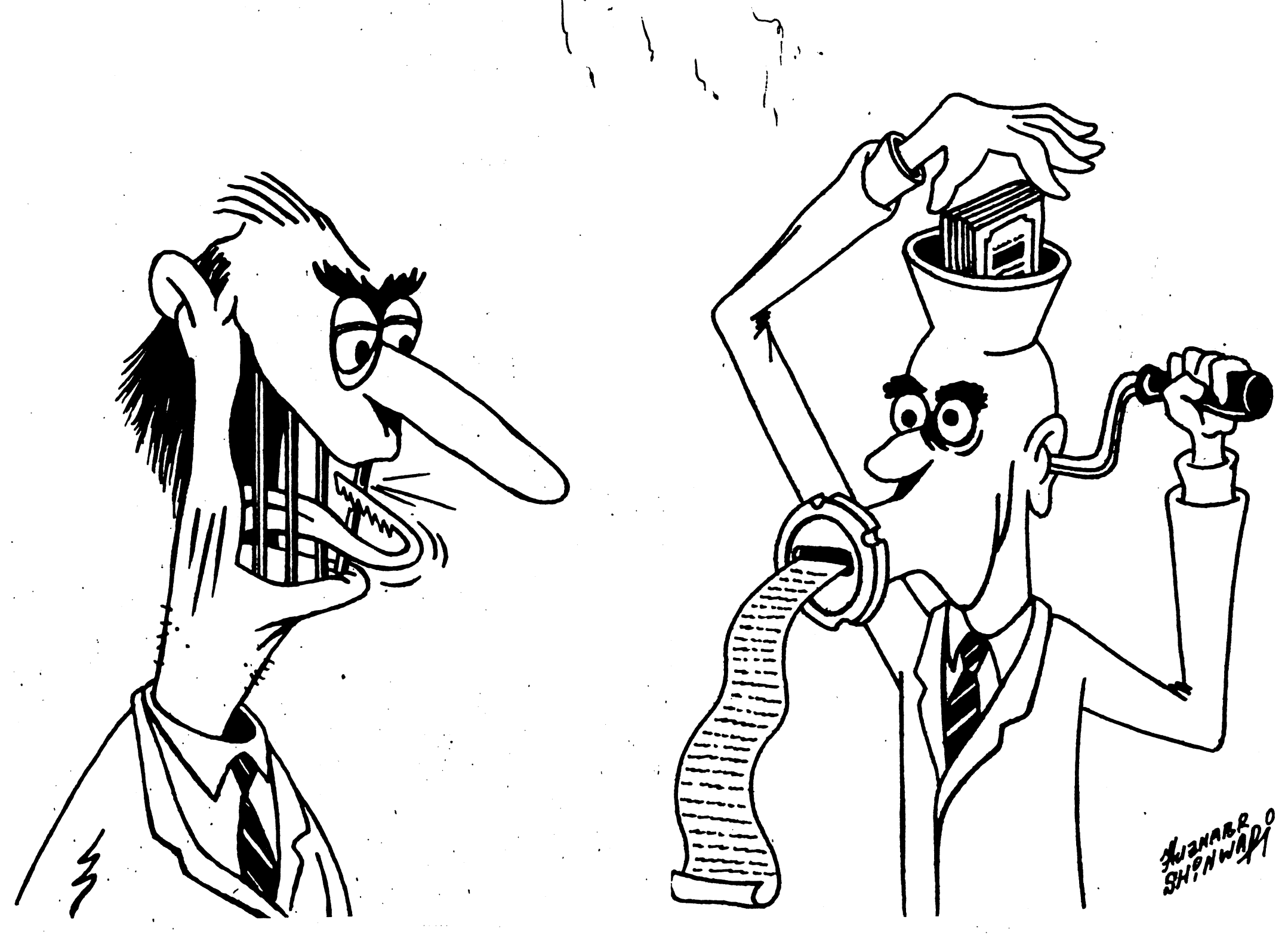


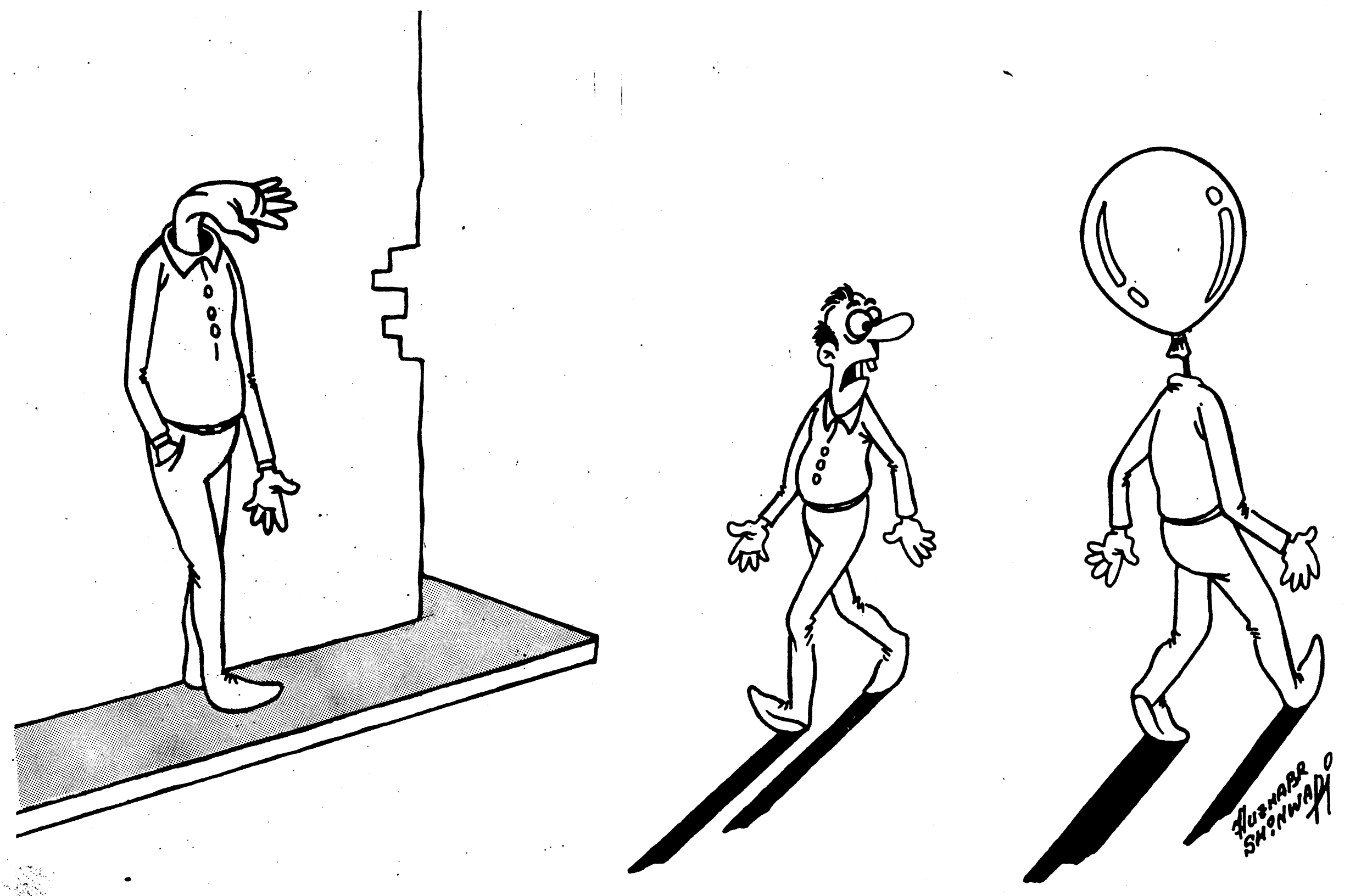


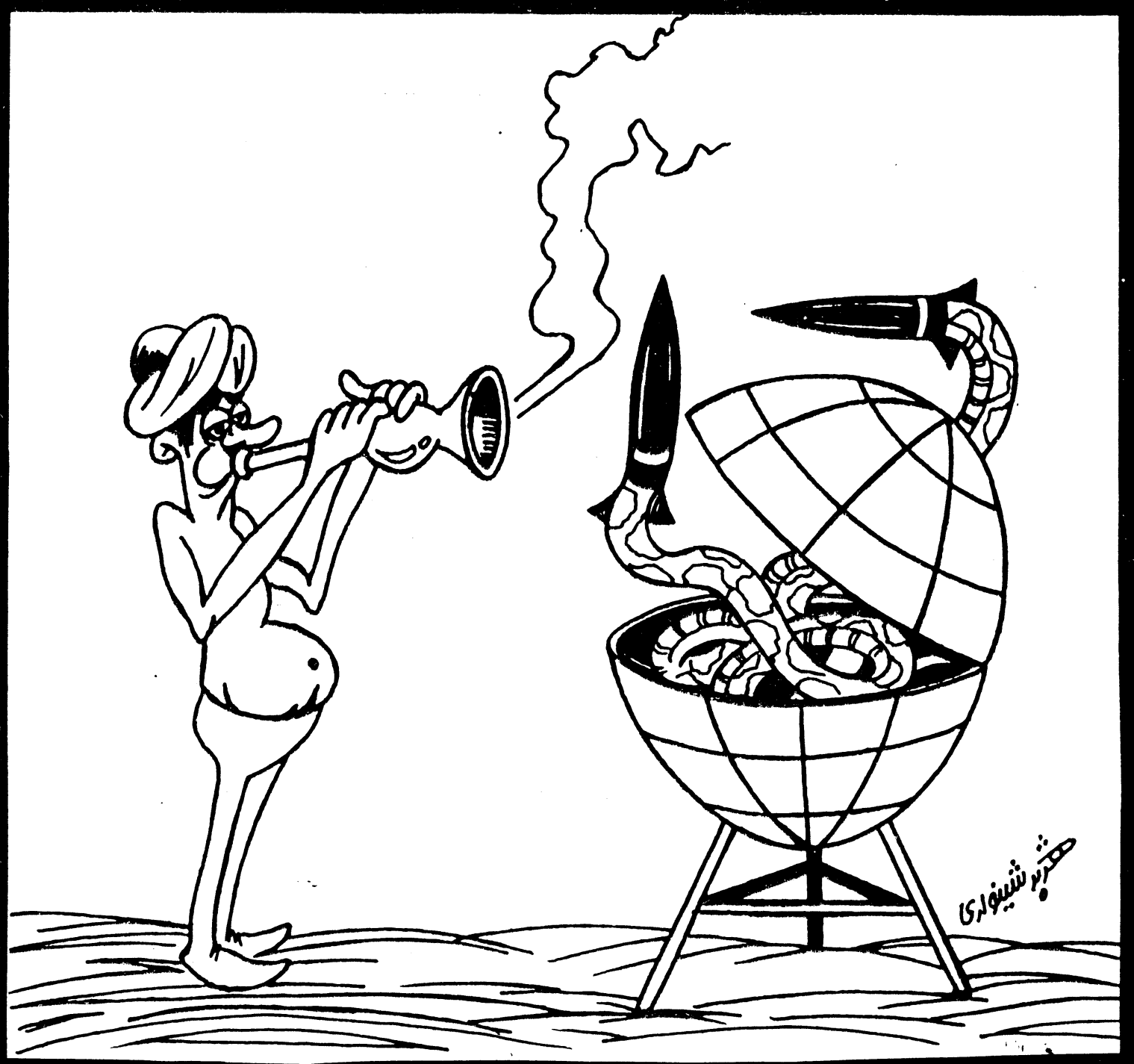



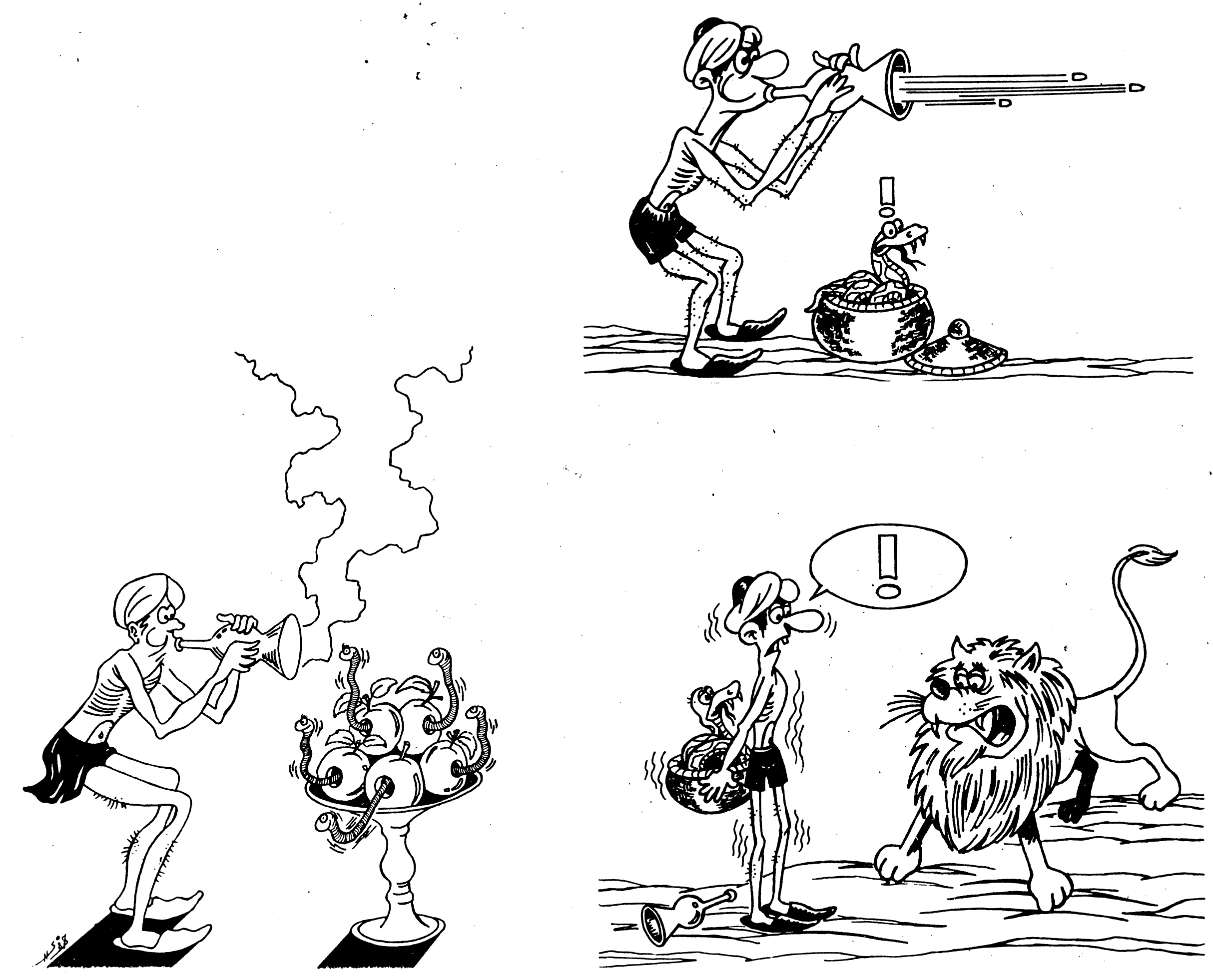



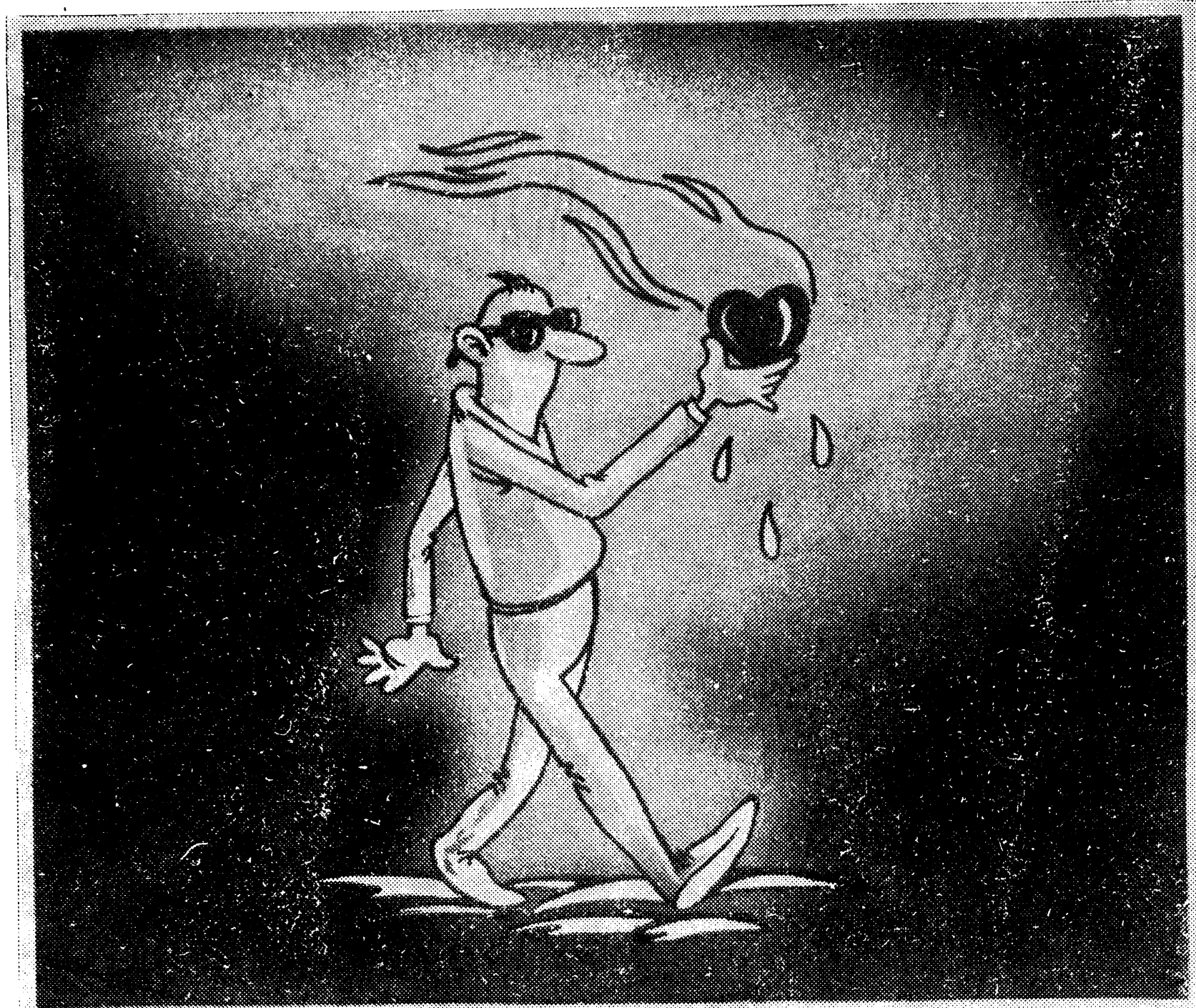



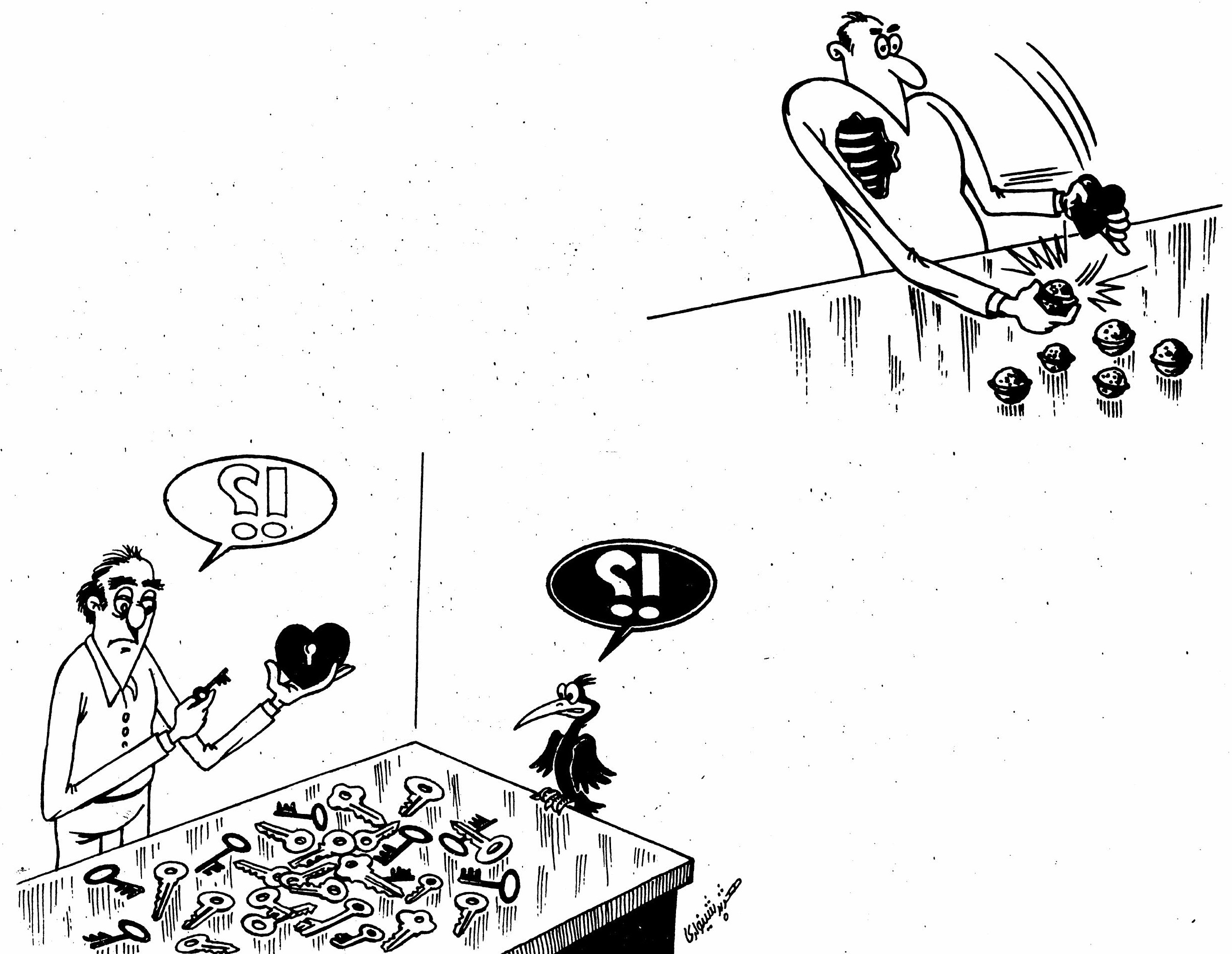
$\therefore$

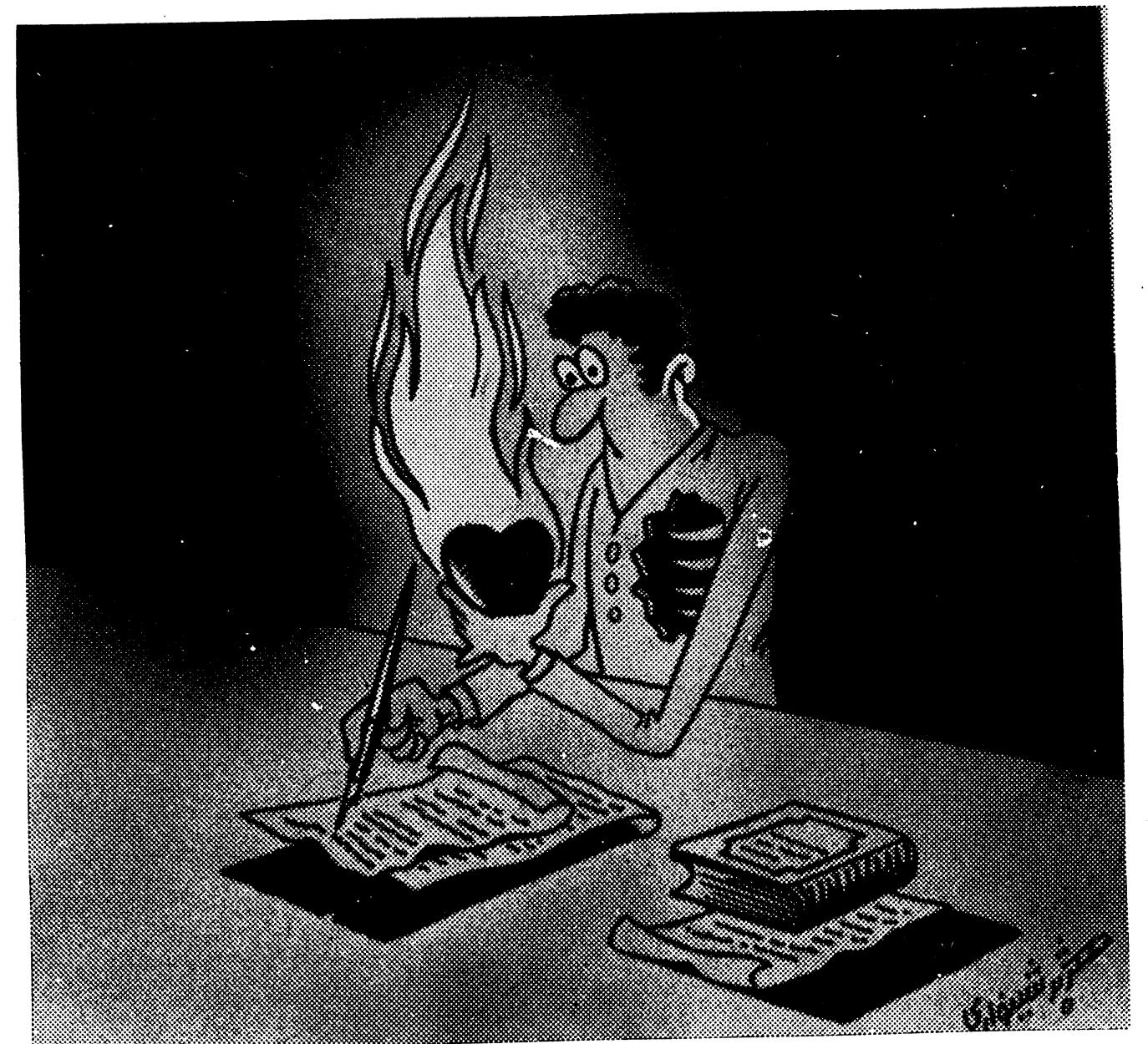




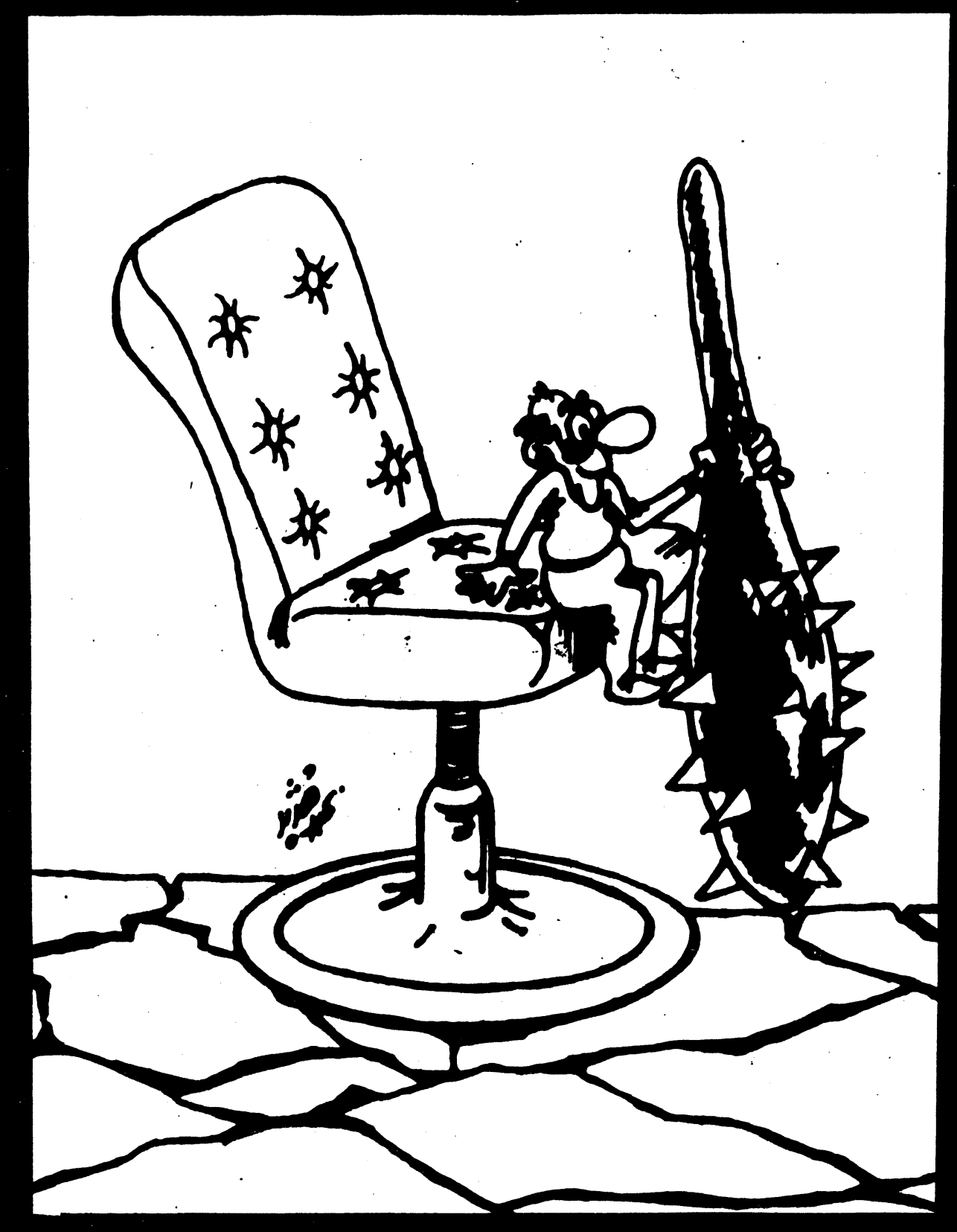




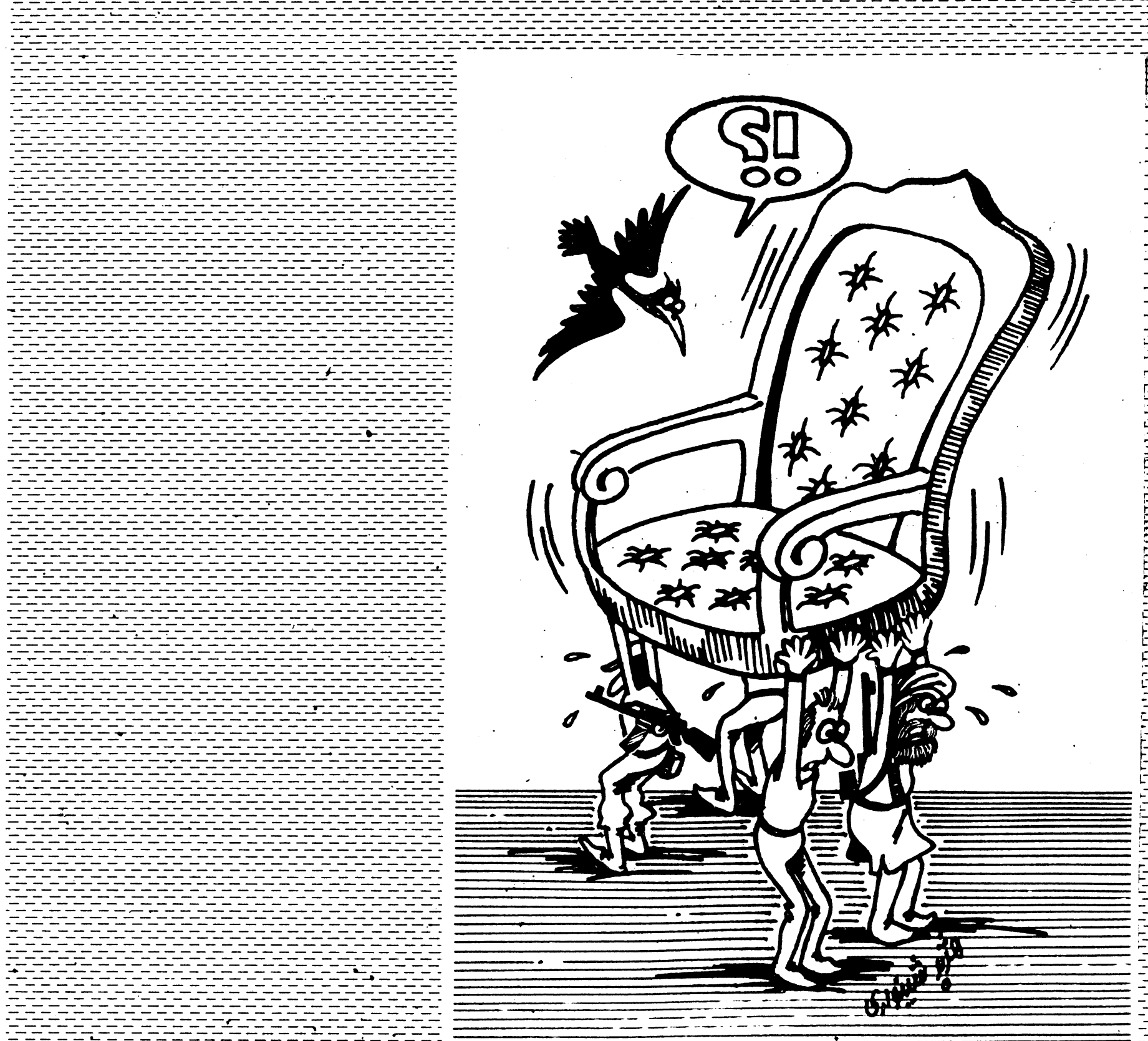

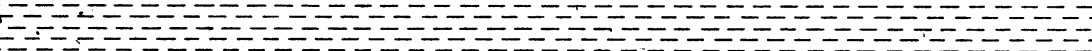



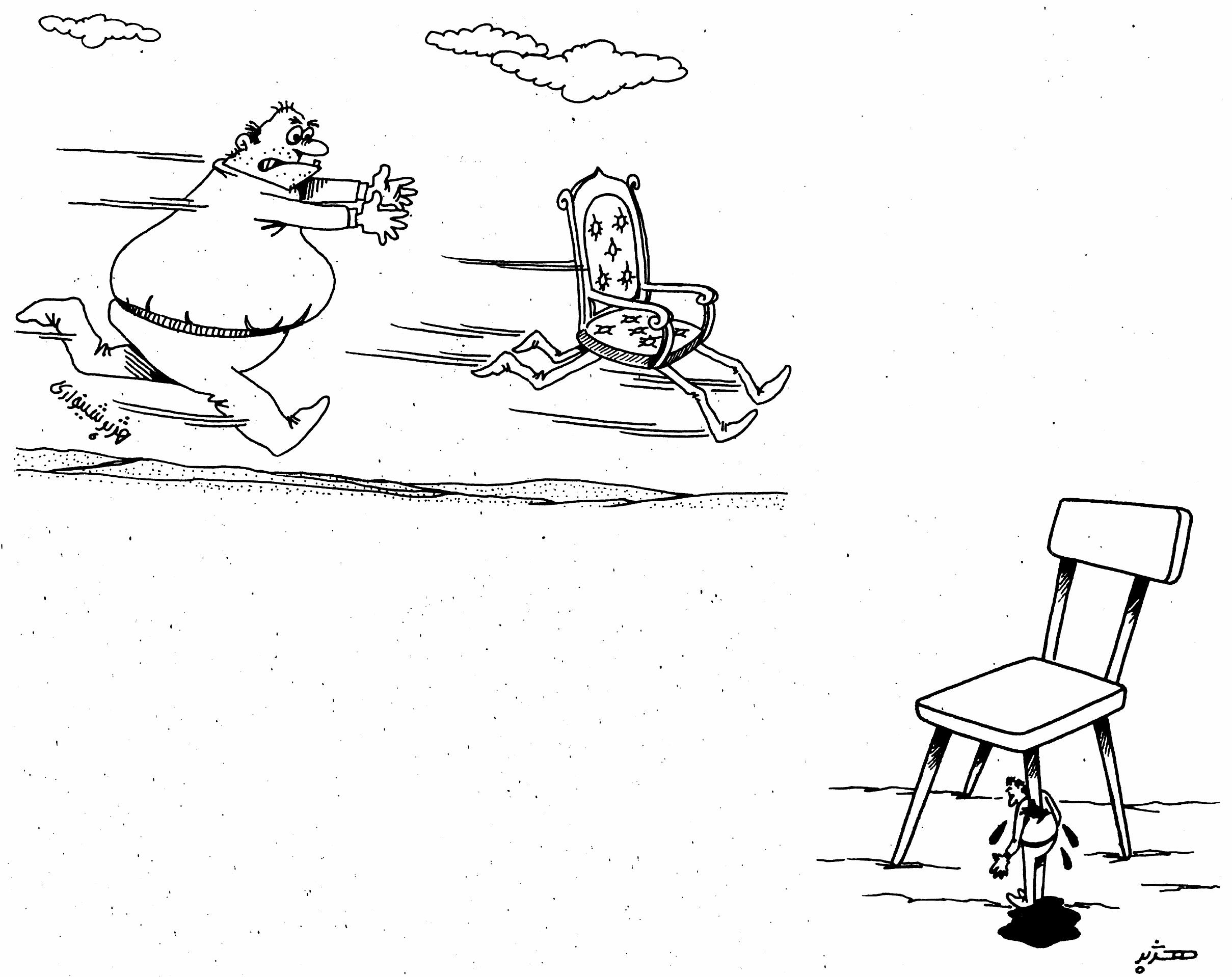

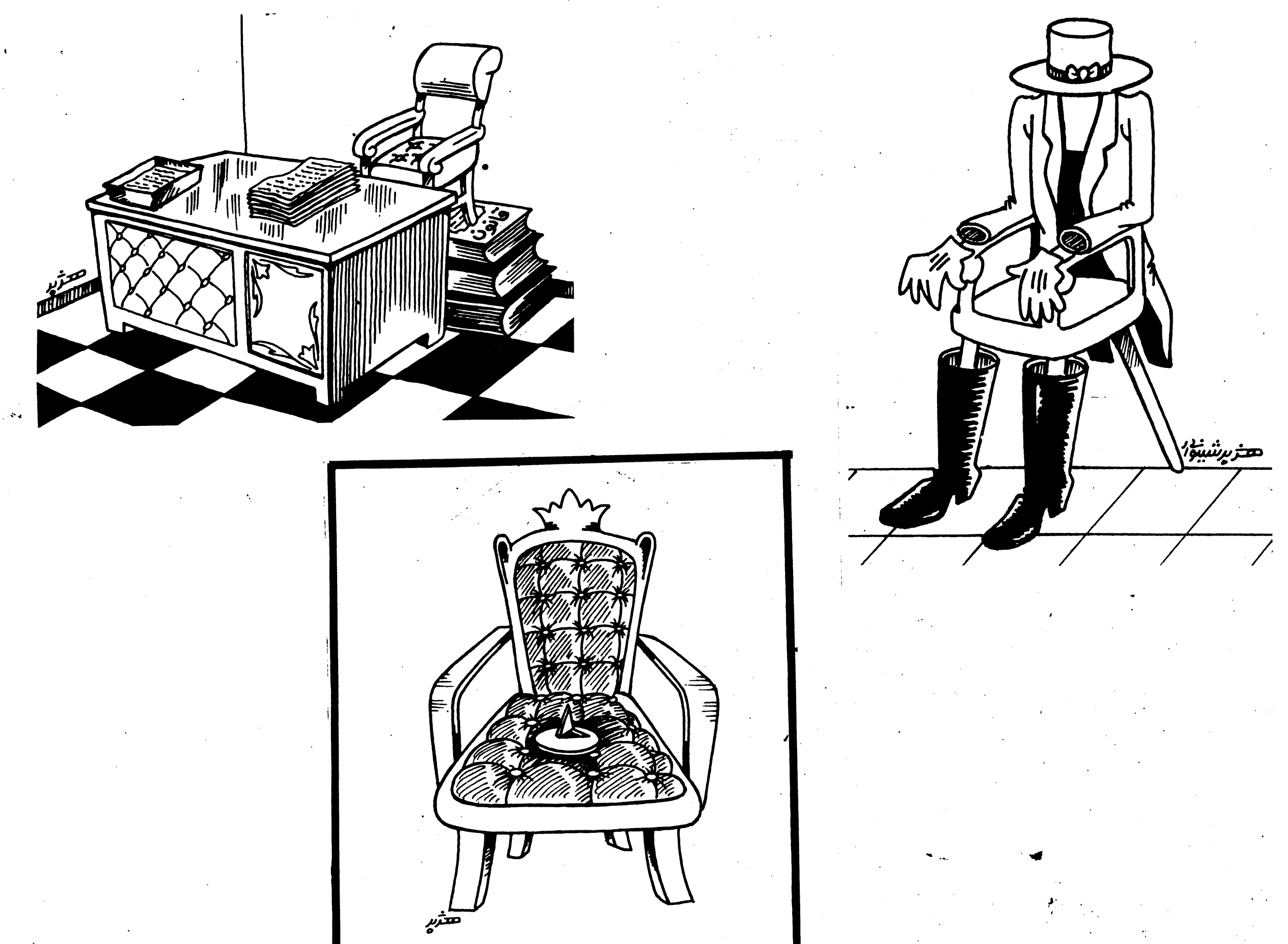

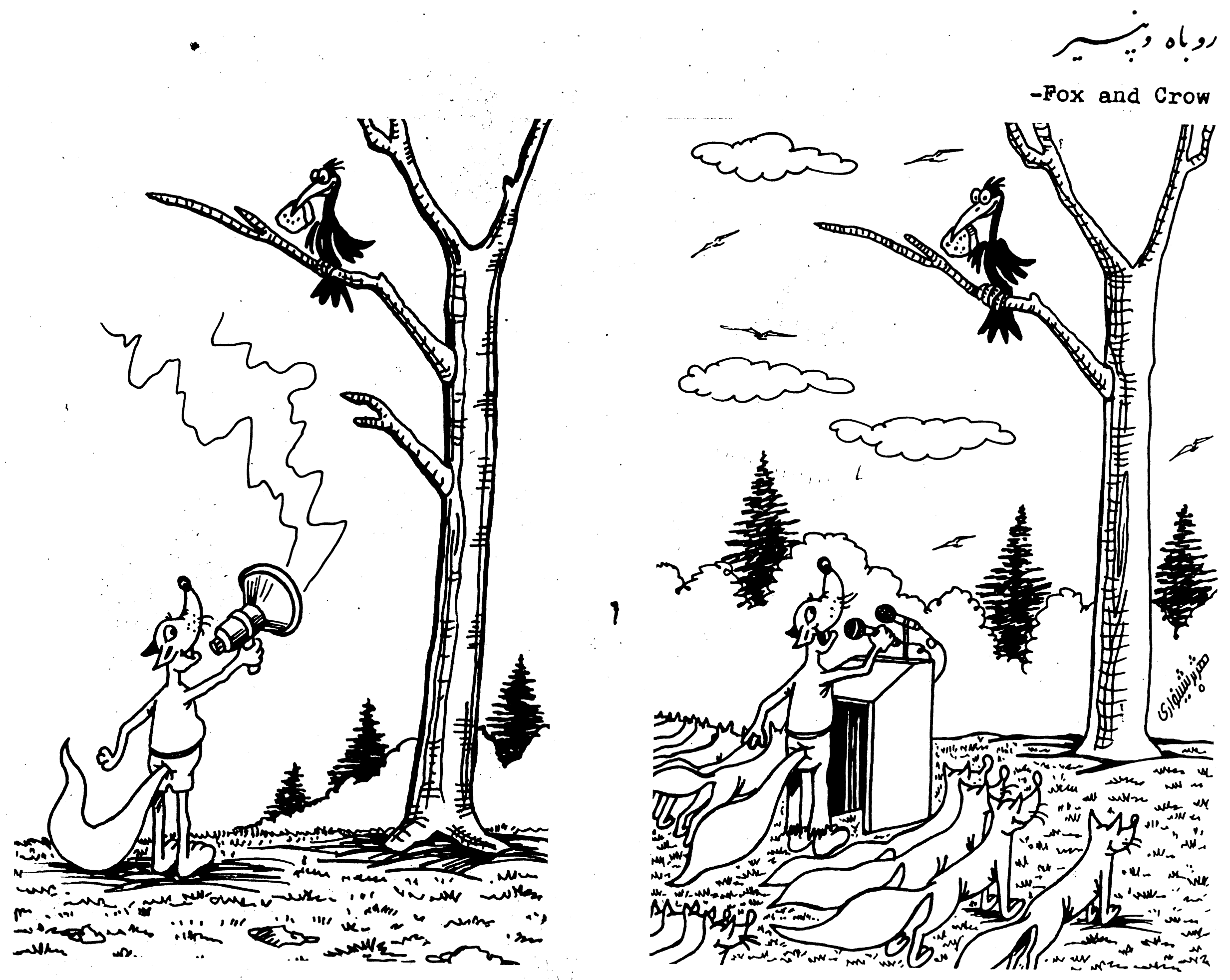

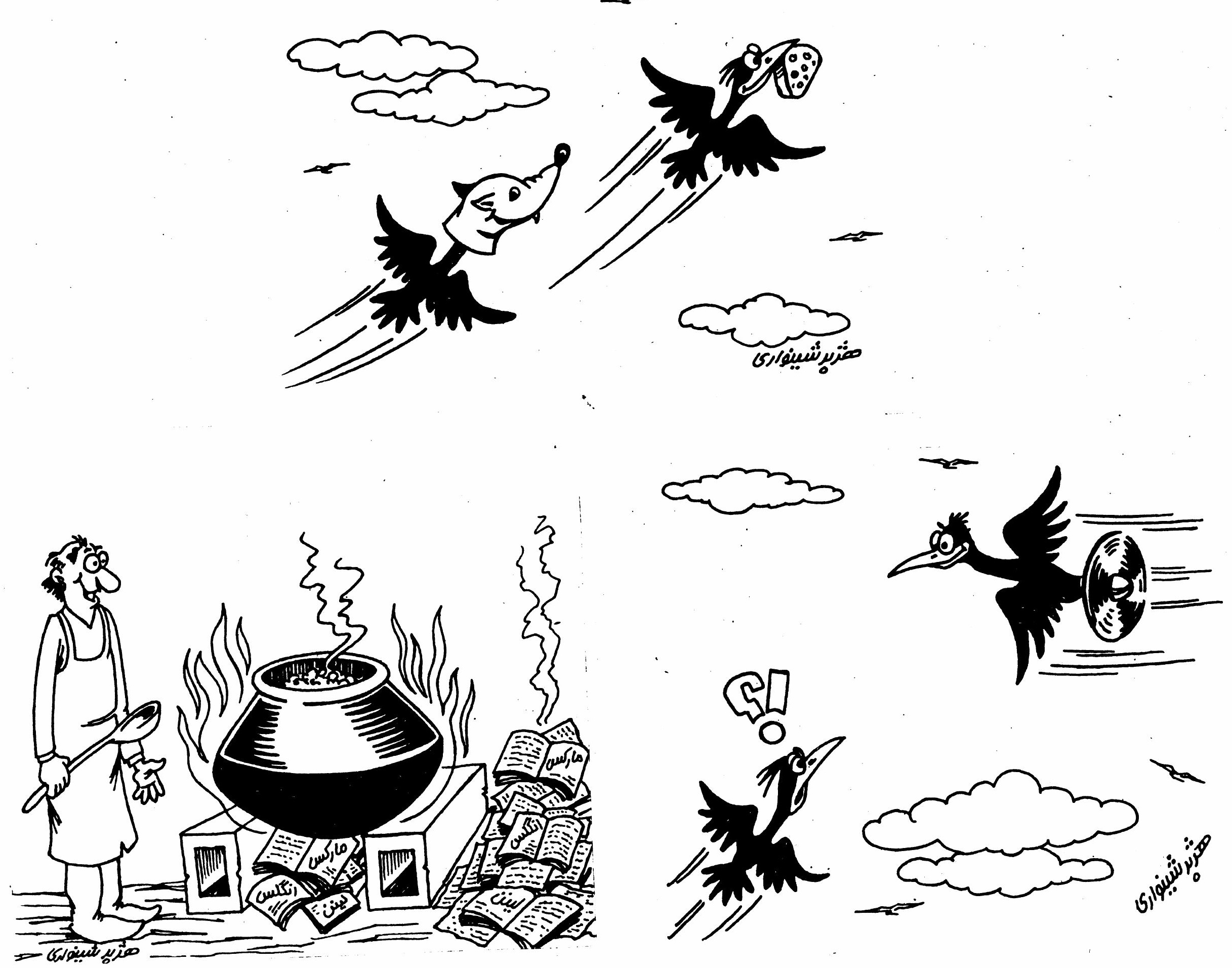


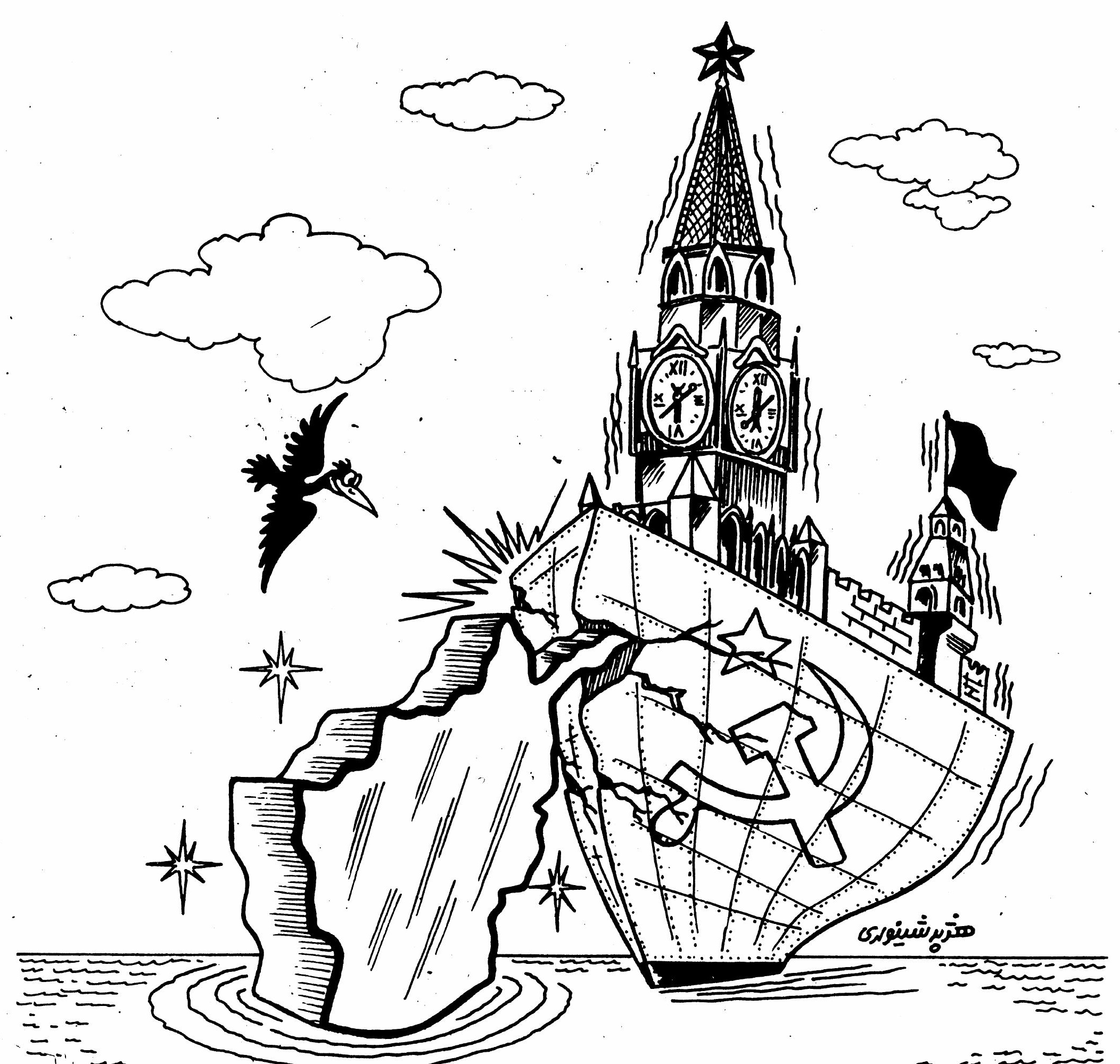



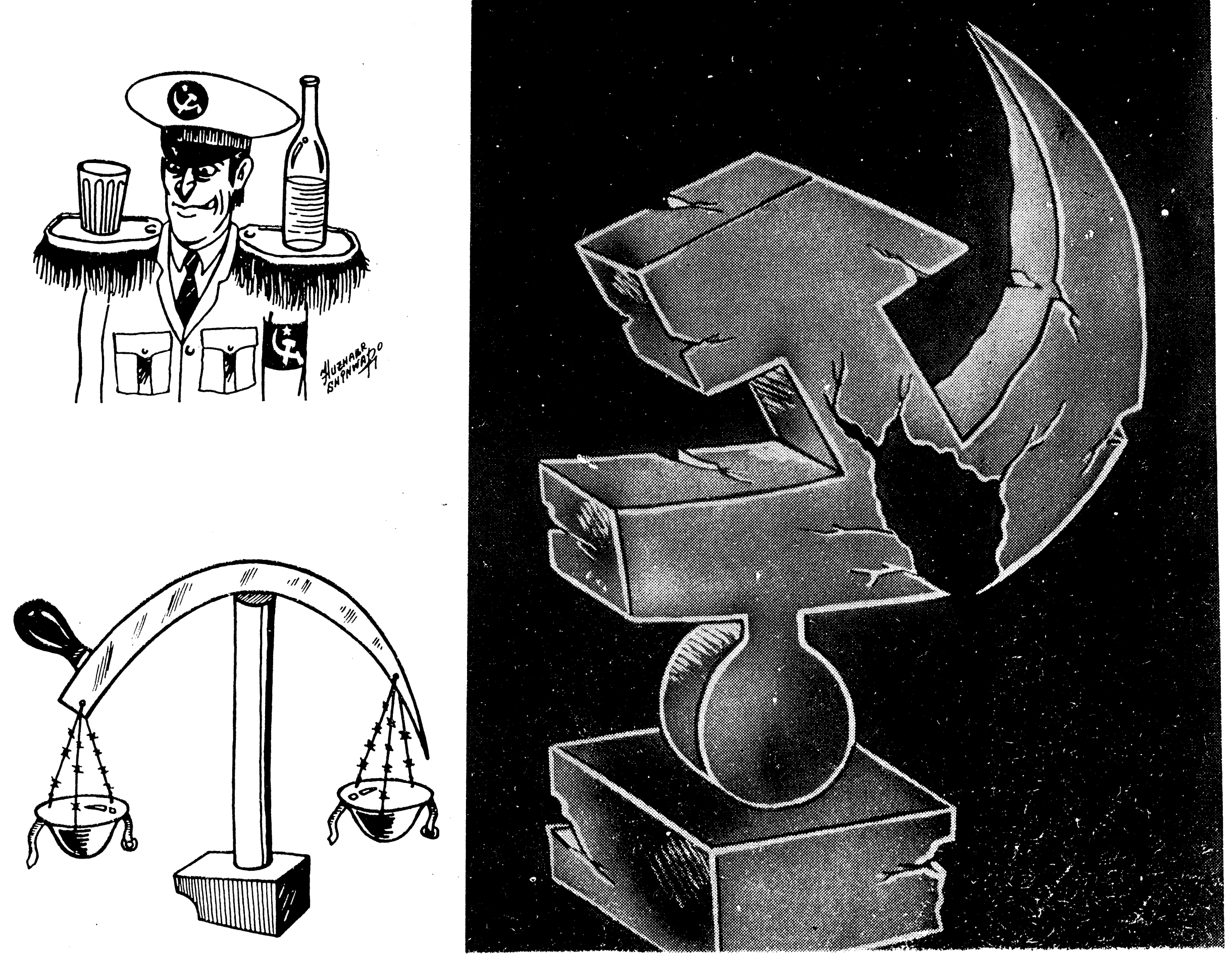


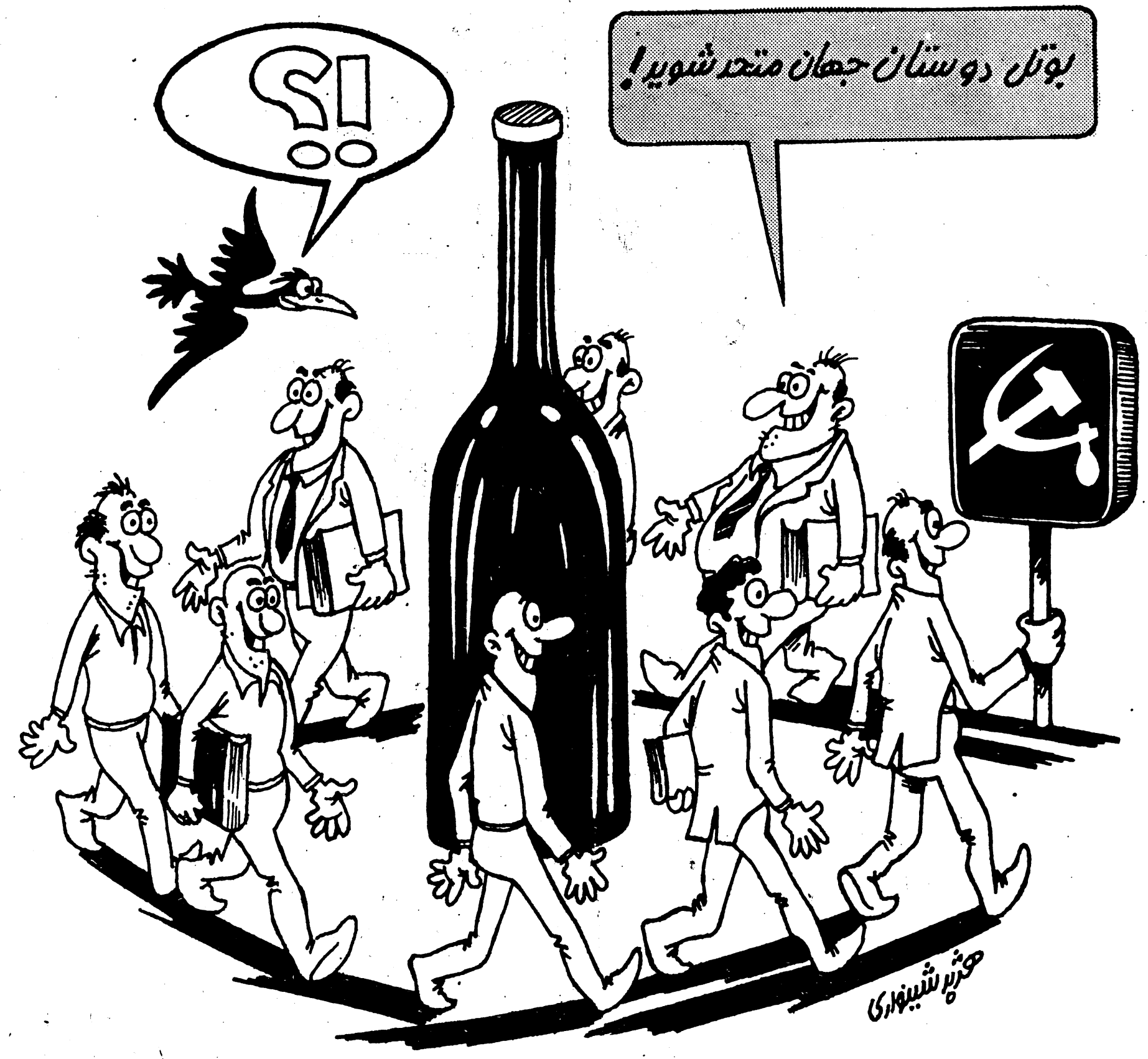

-Bottle Iovere of the world,cot together 


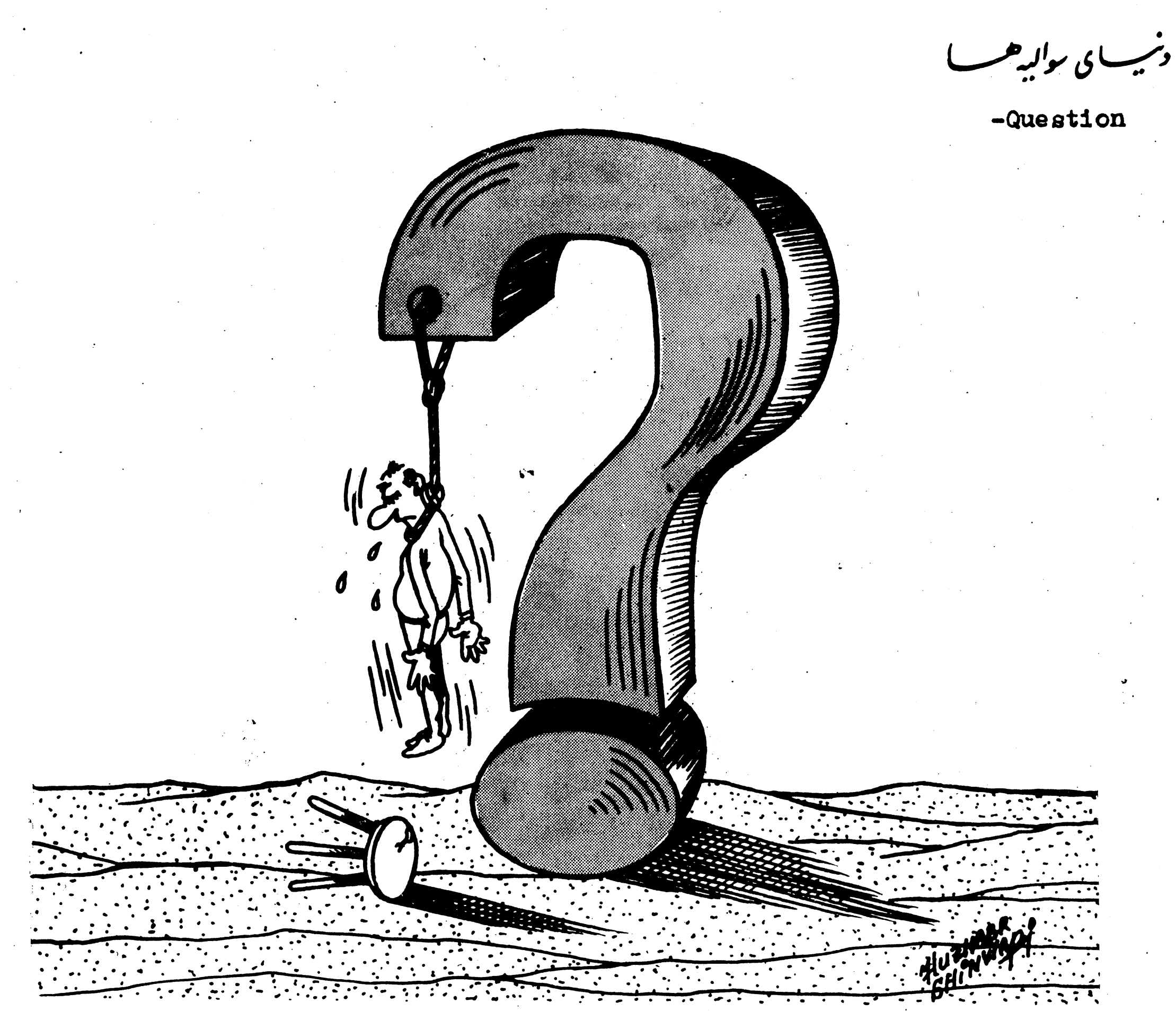



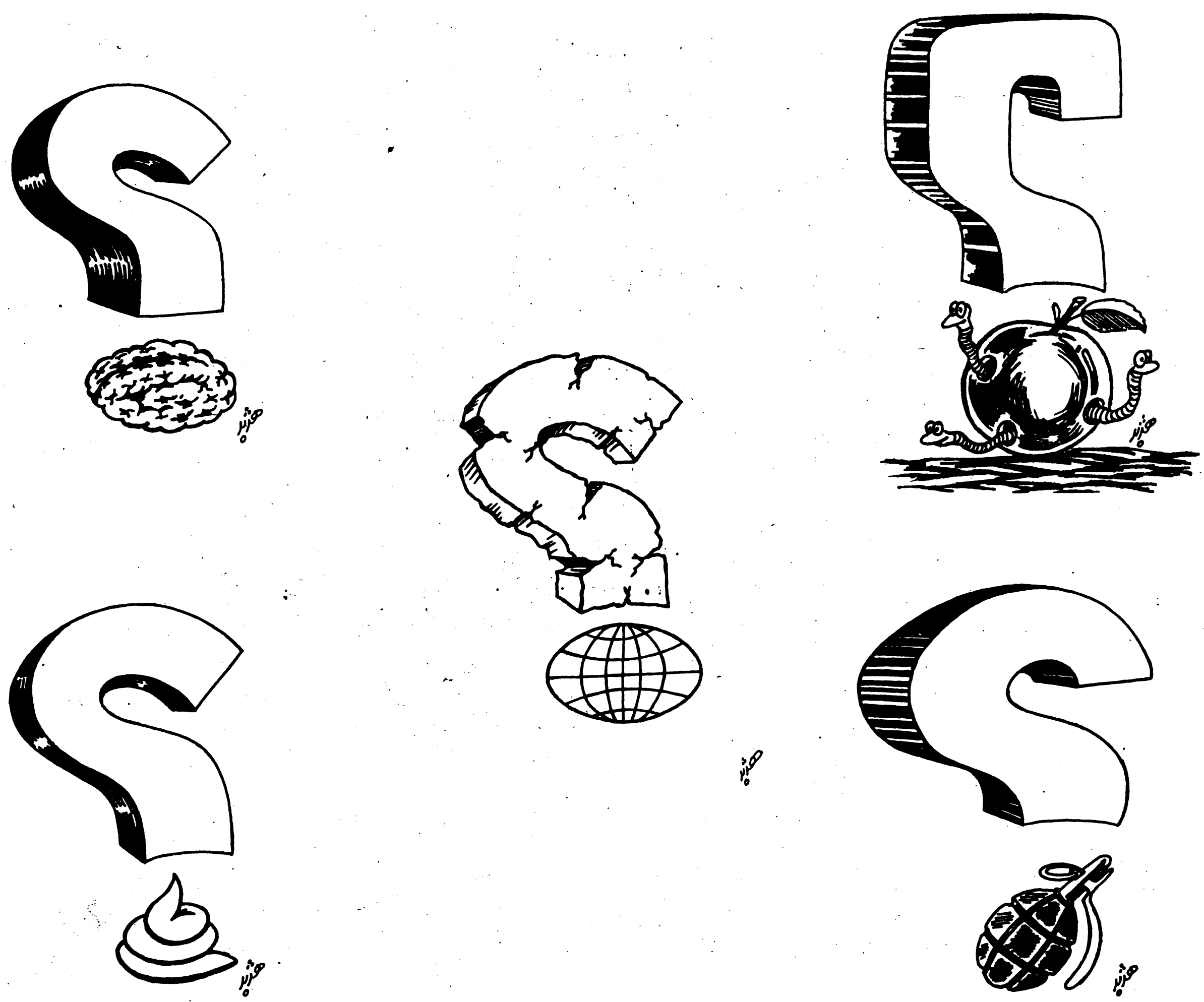

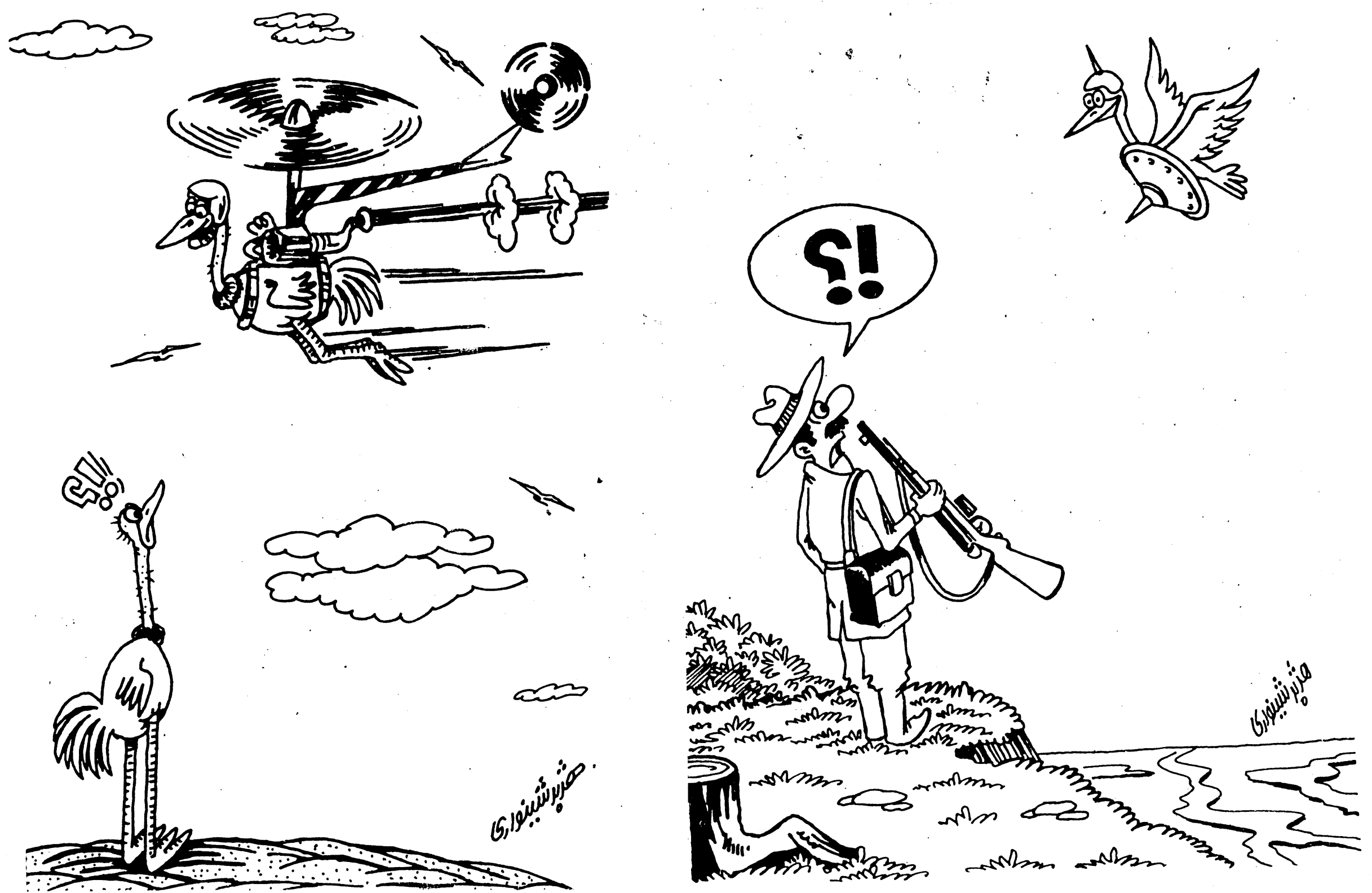

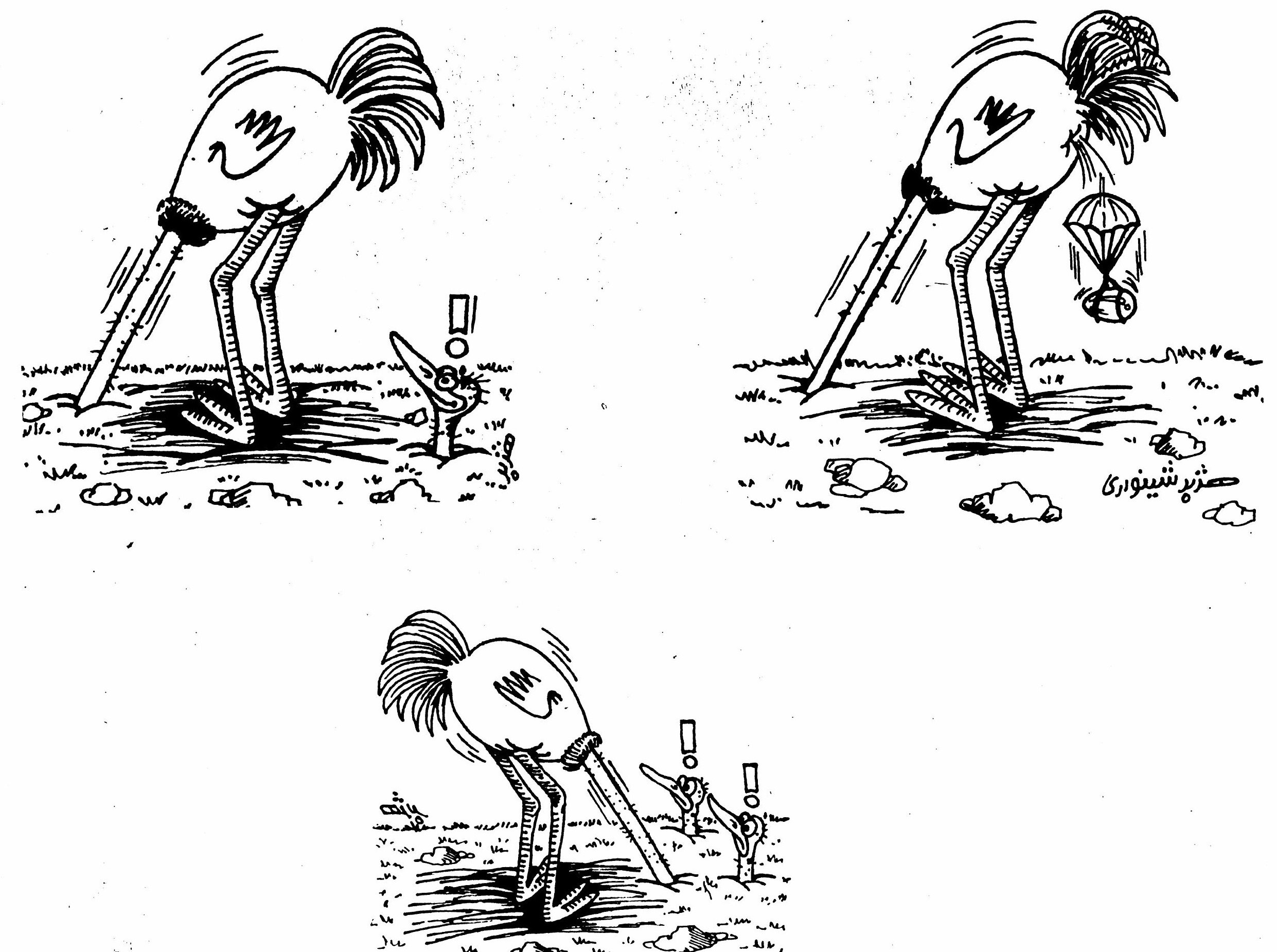



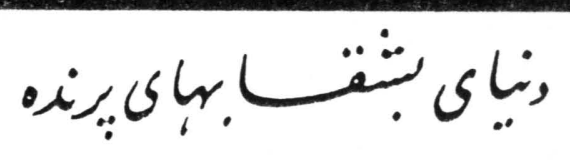

In the World of Flying objects

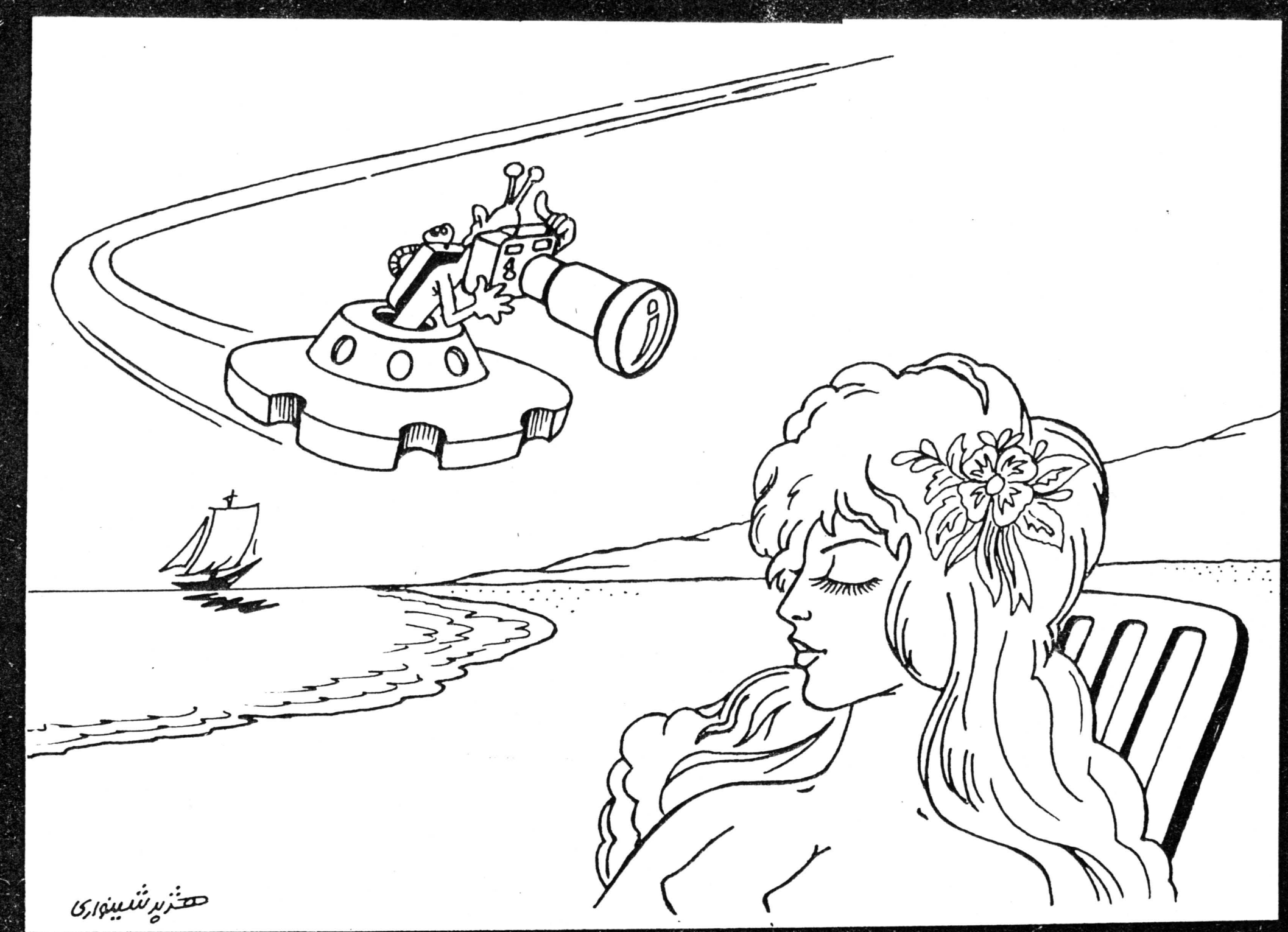




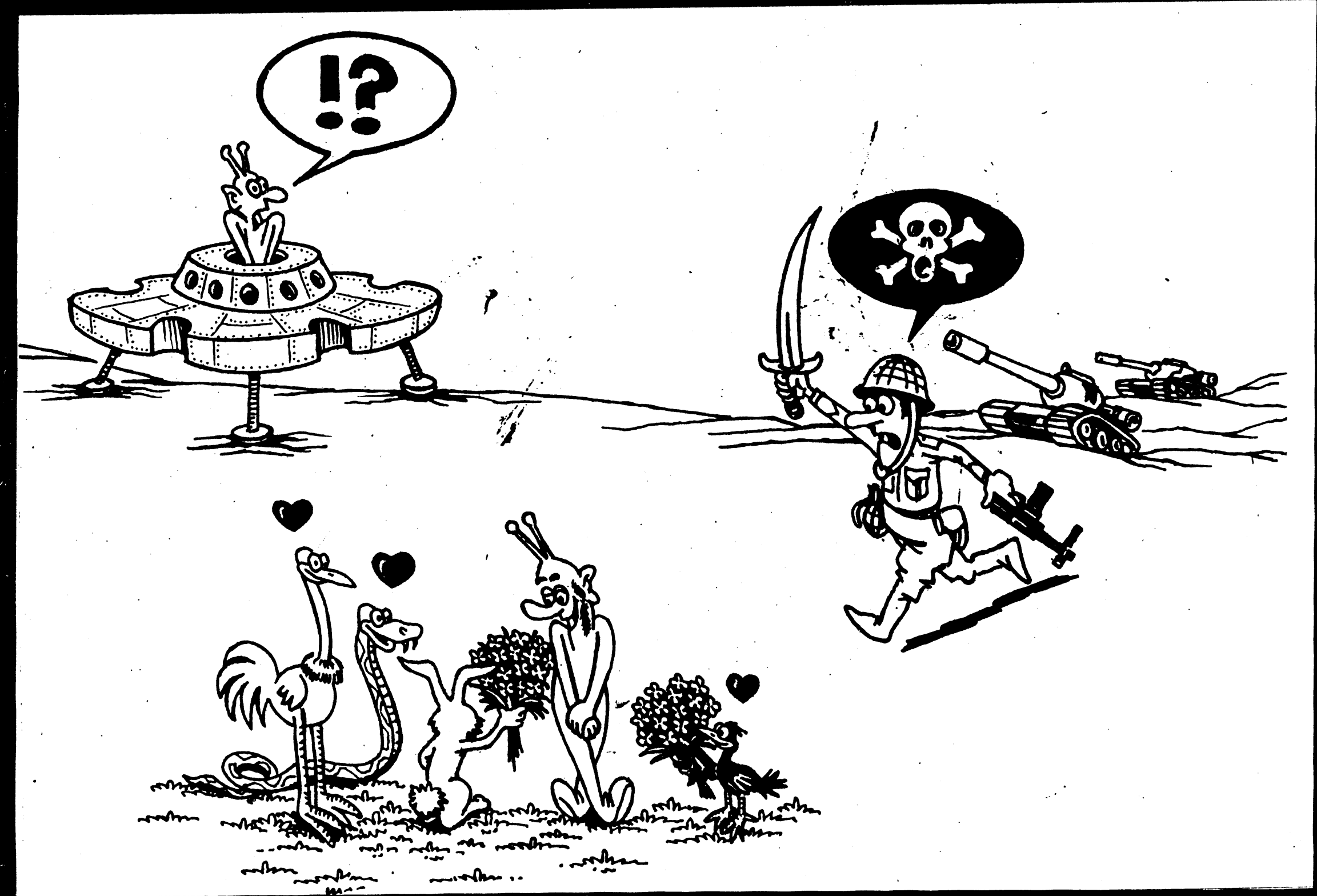



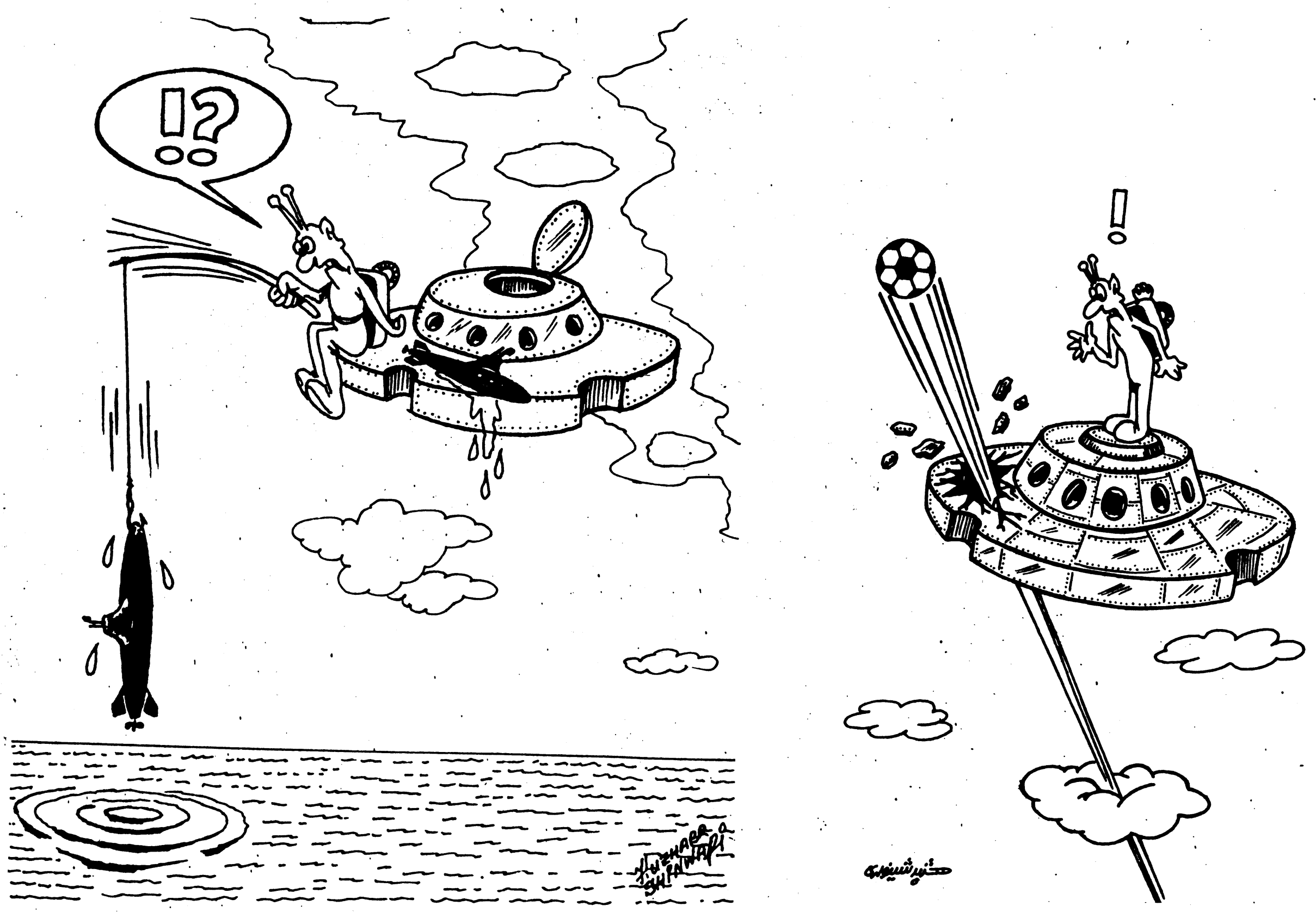

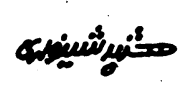






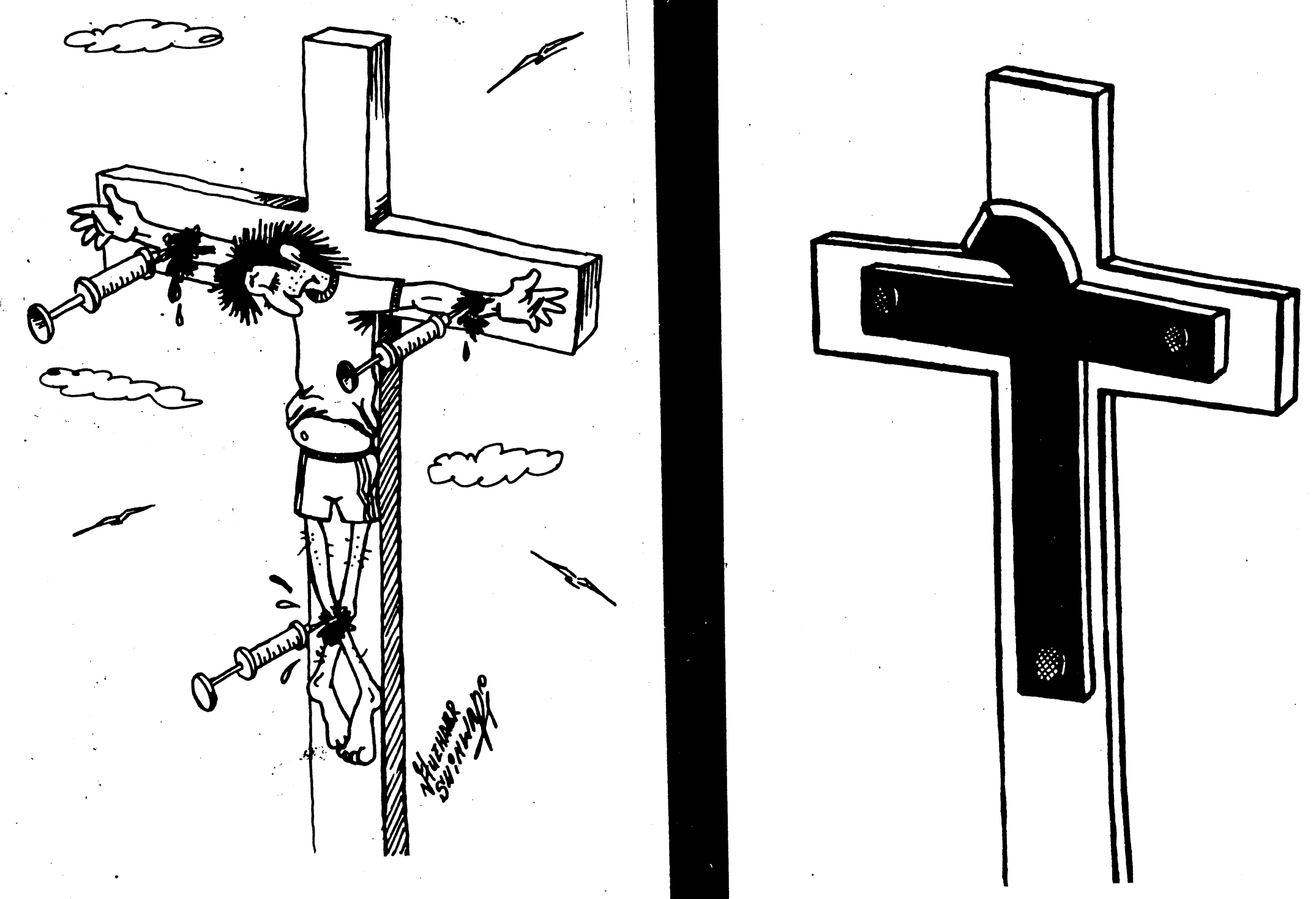


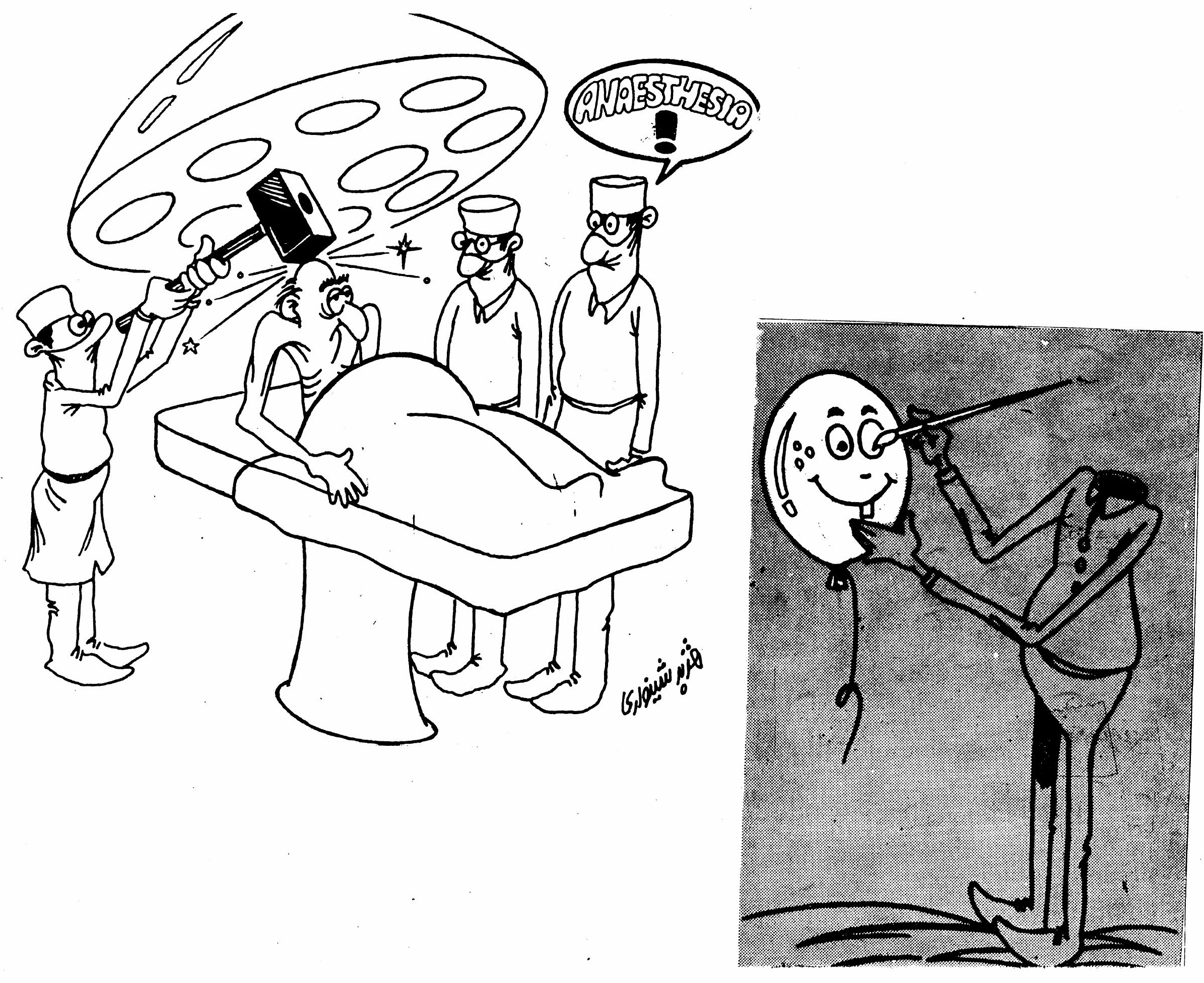



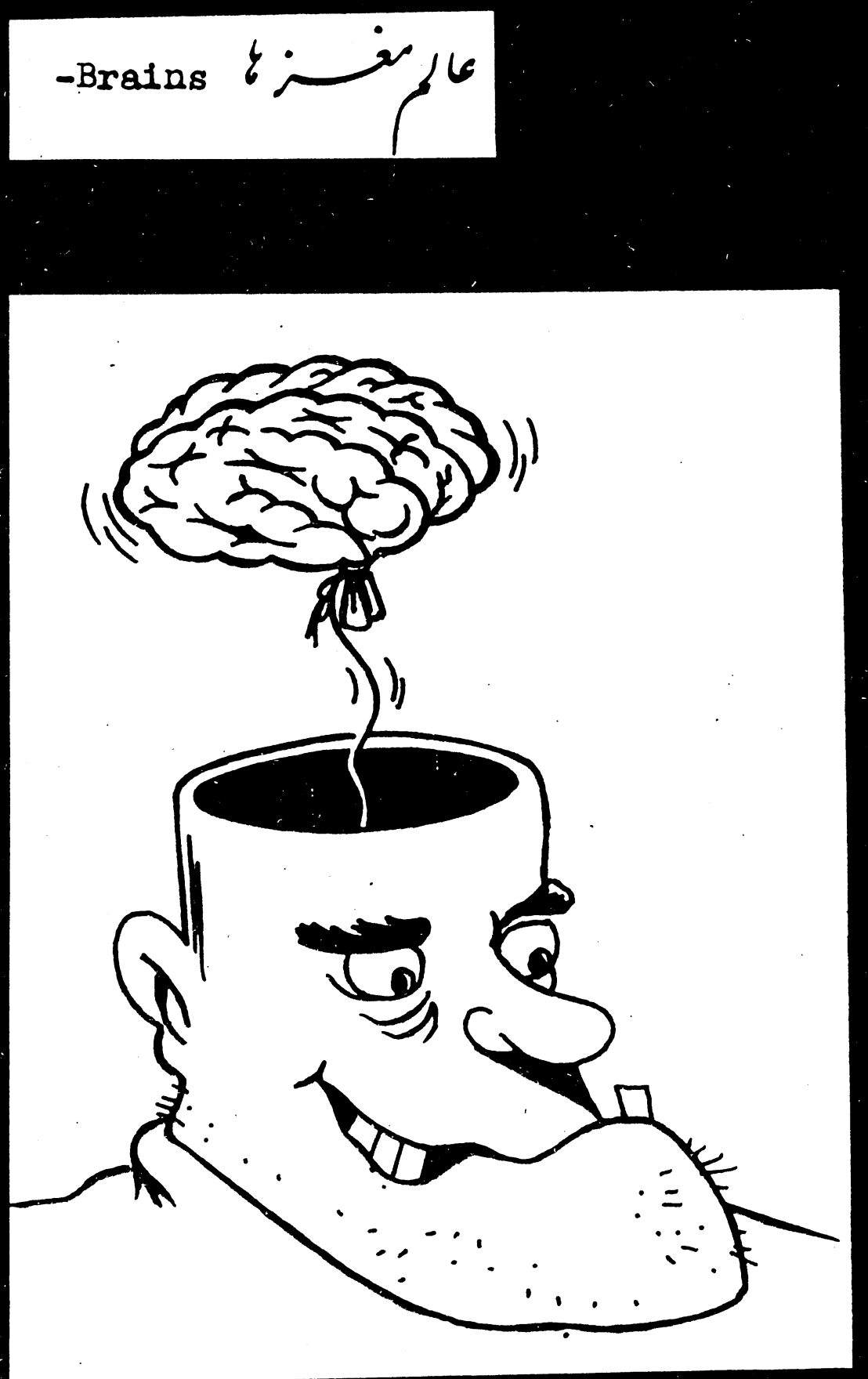



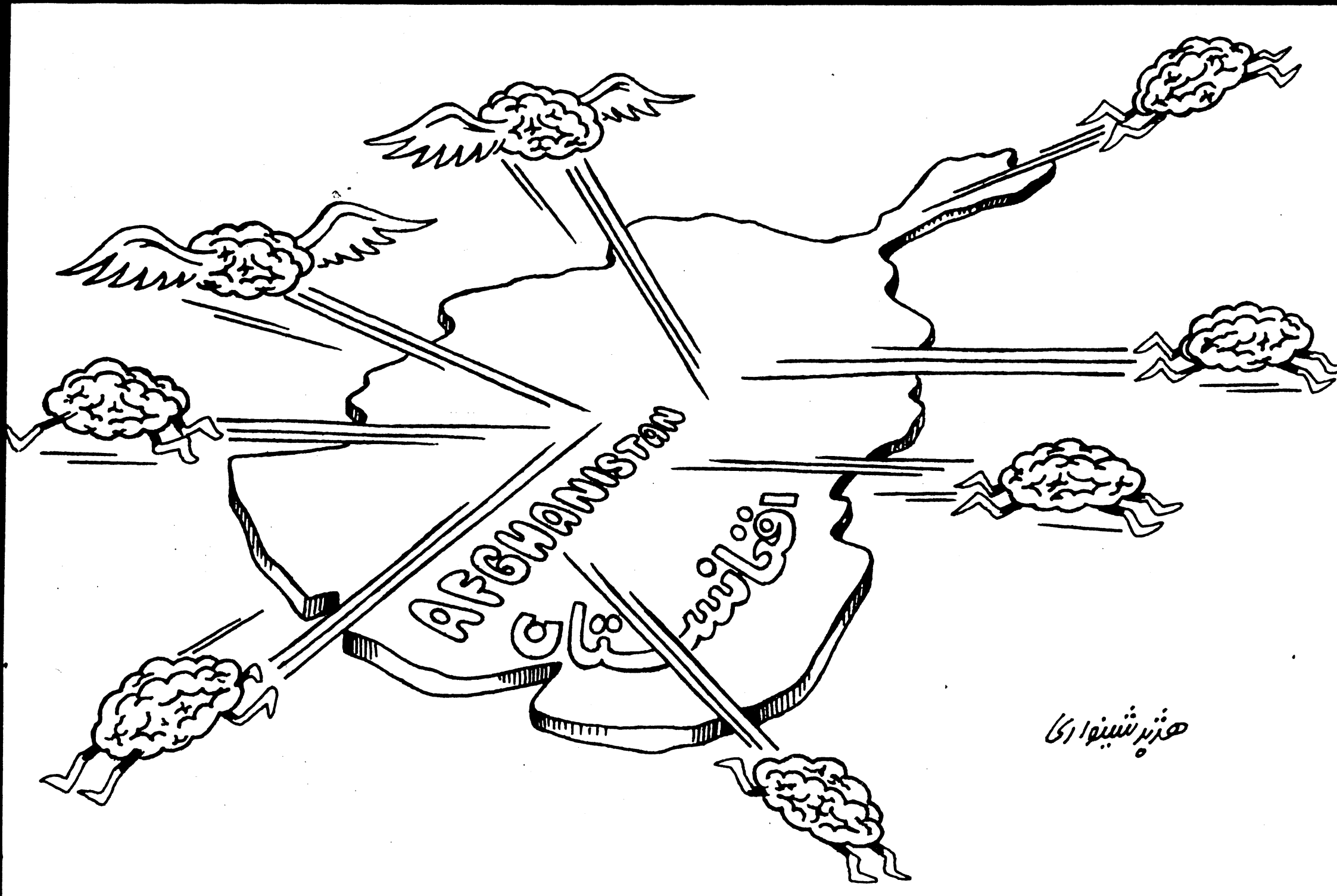




\section{Shadows}
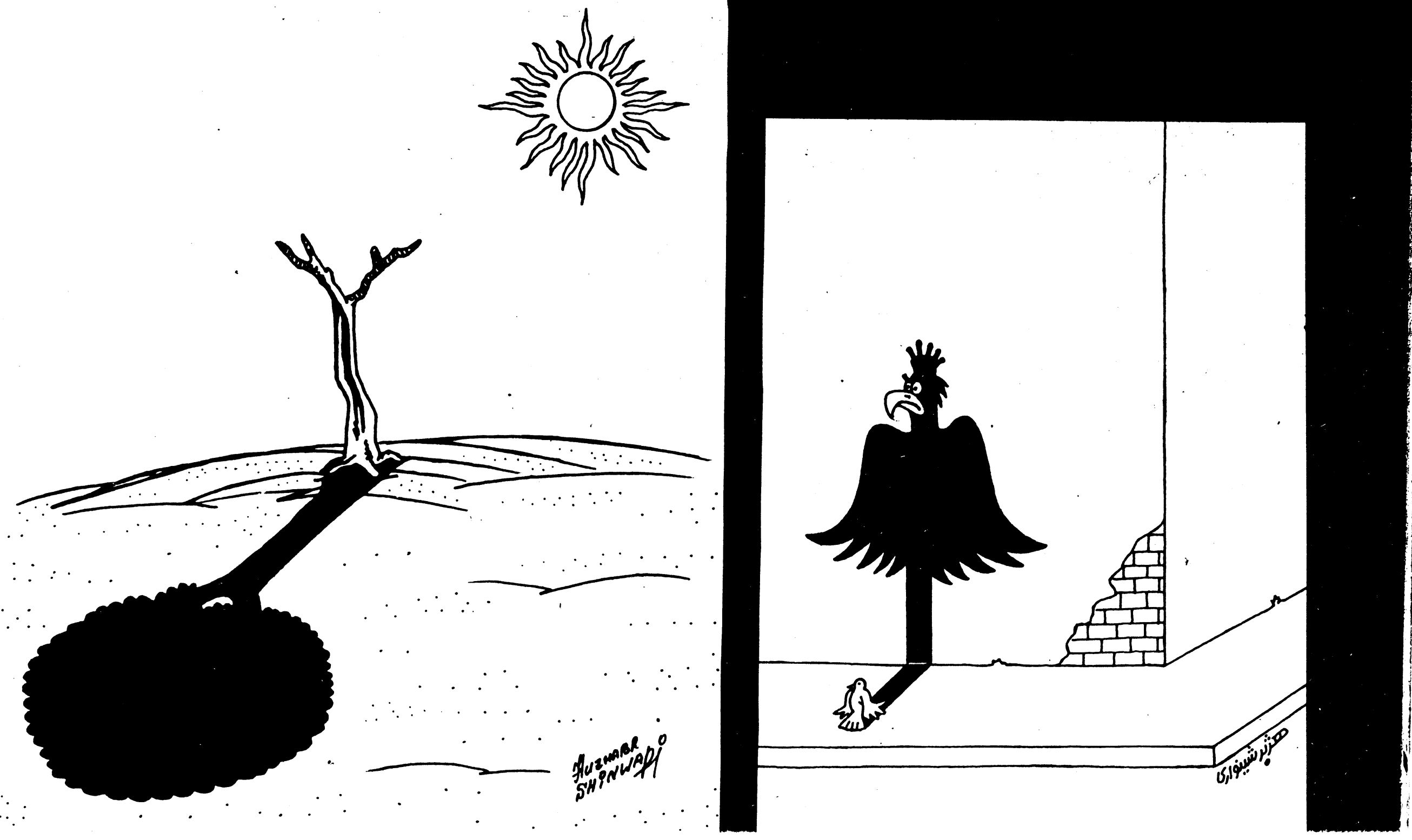


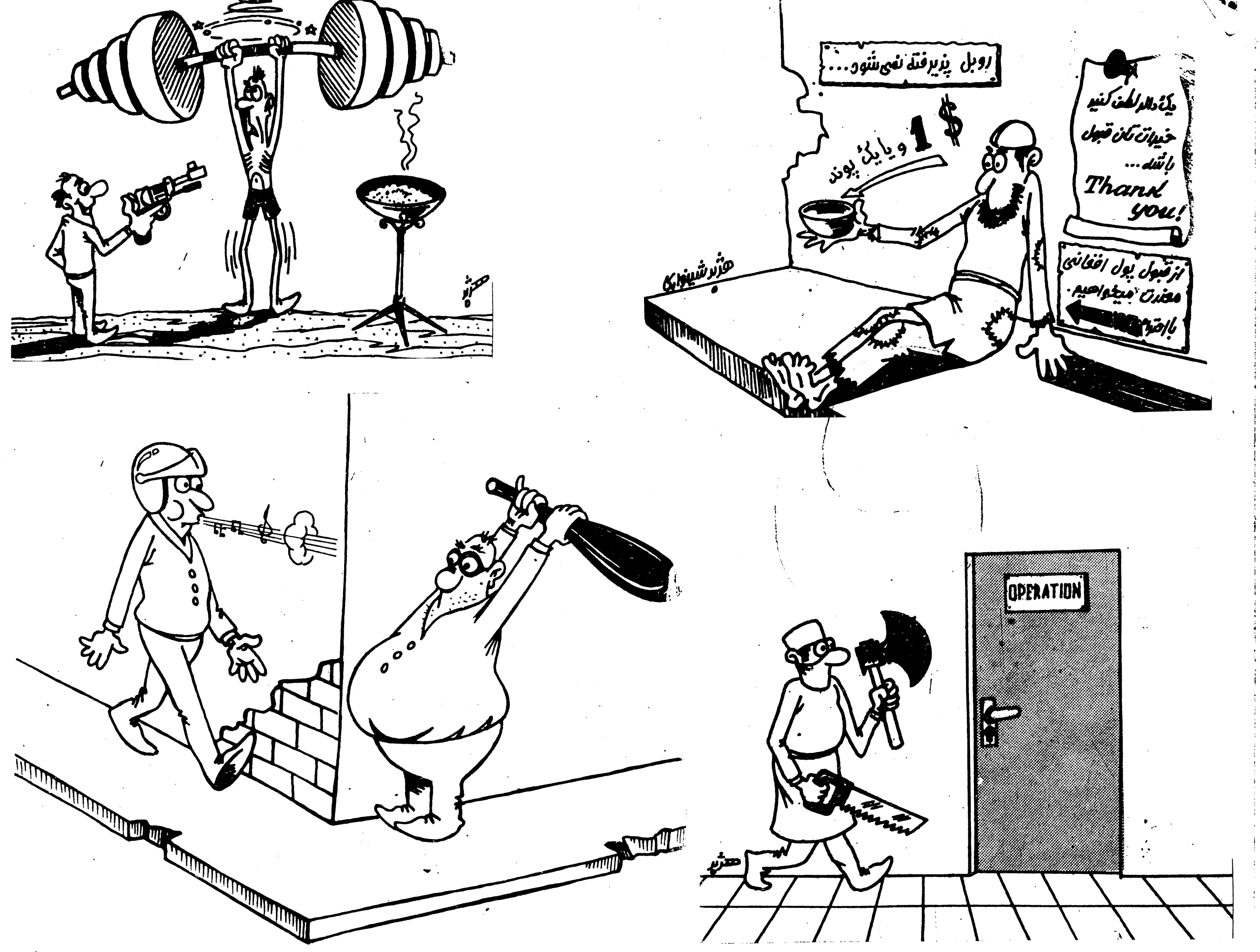



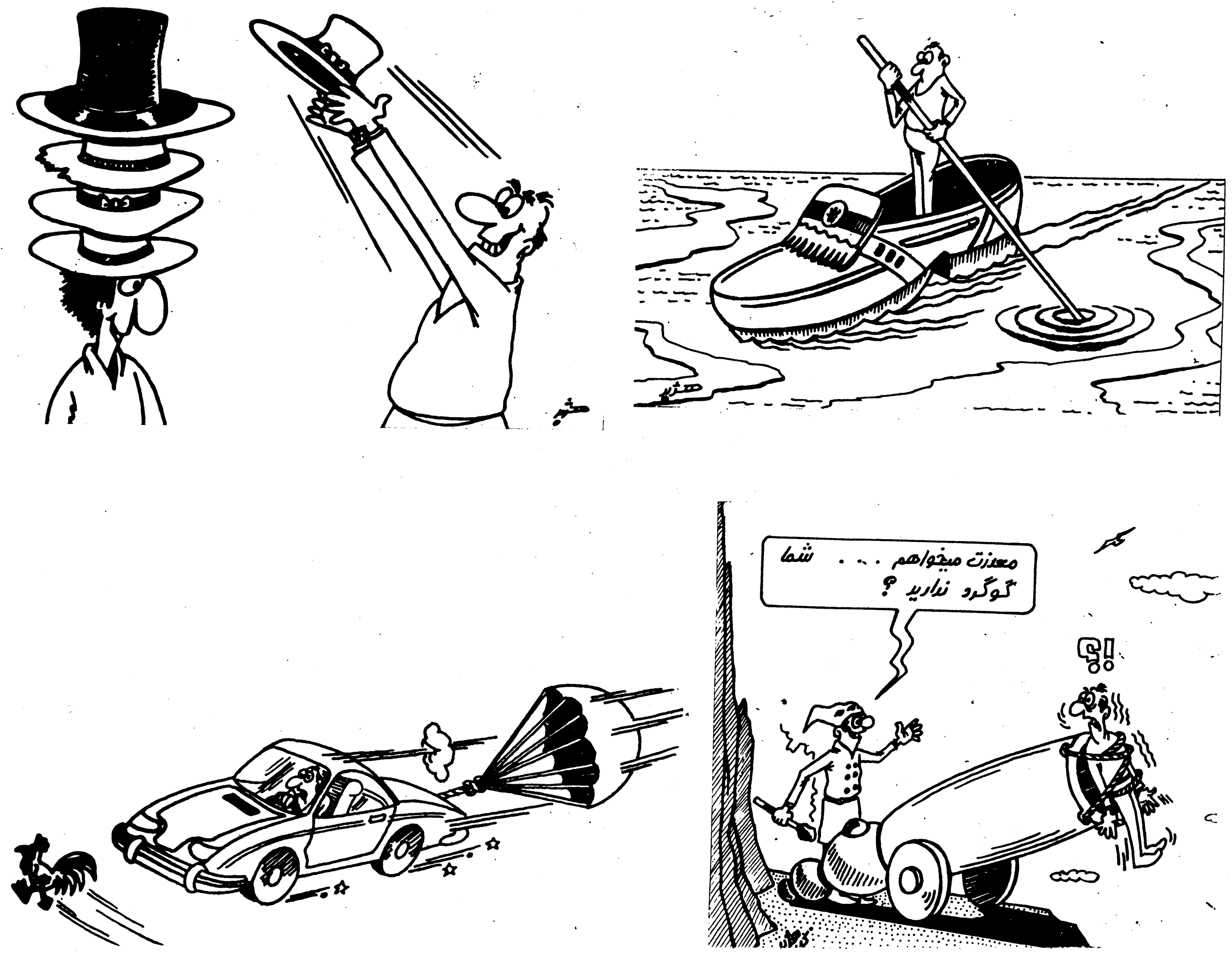






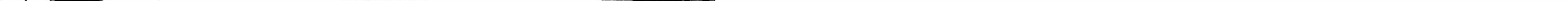




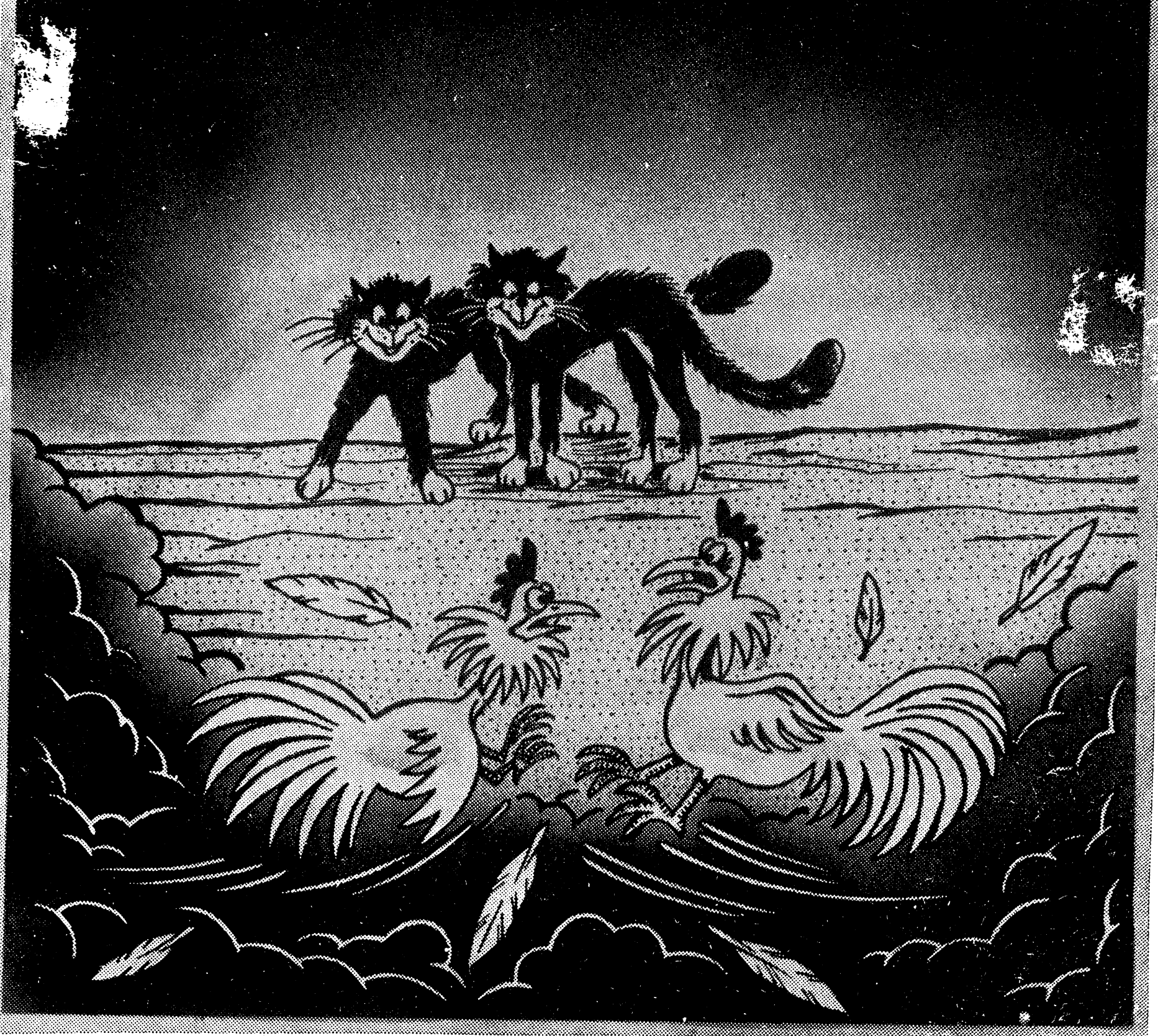




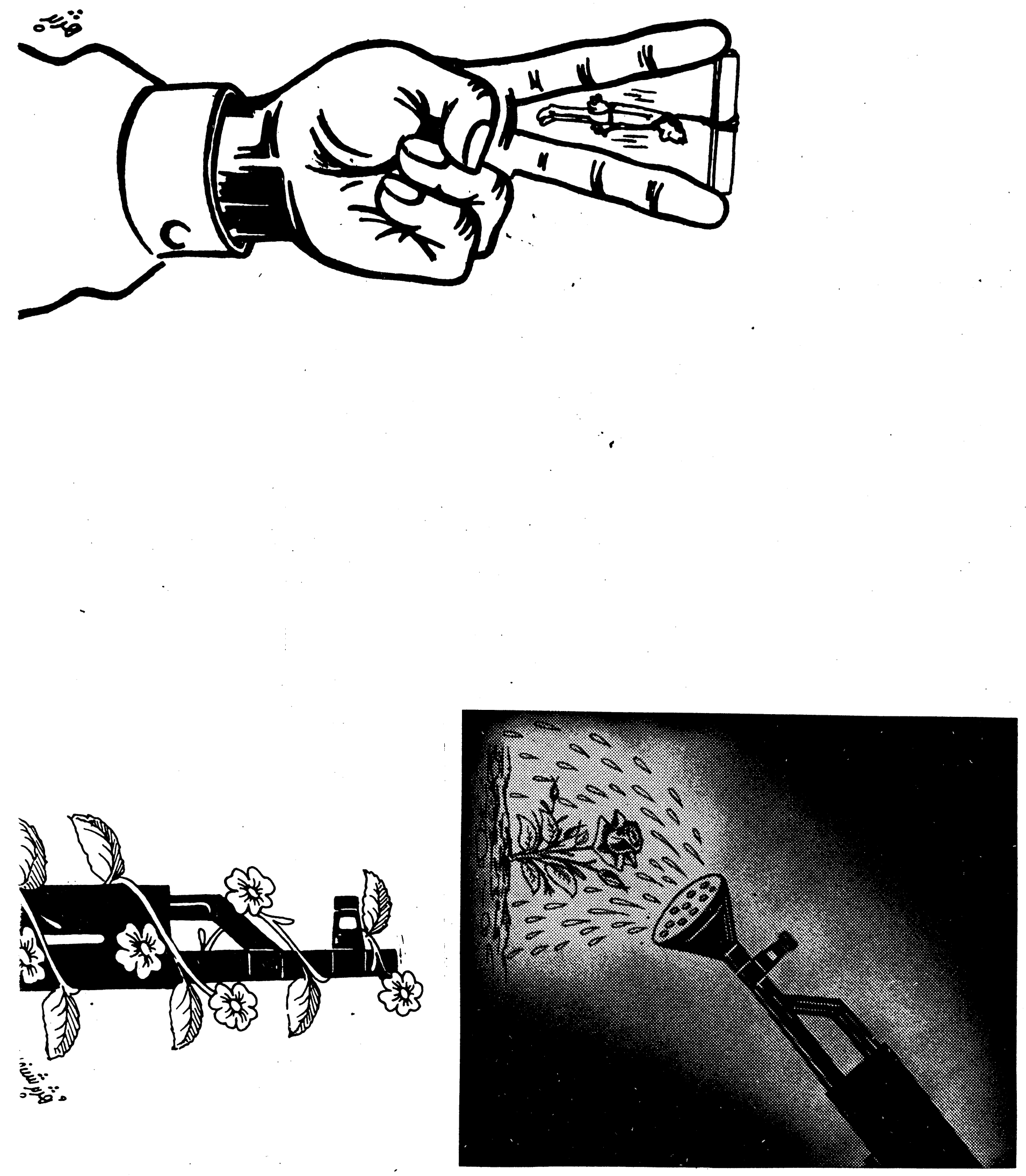


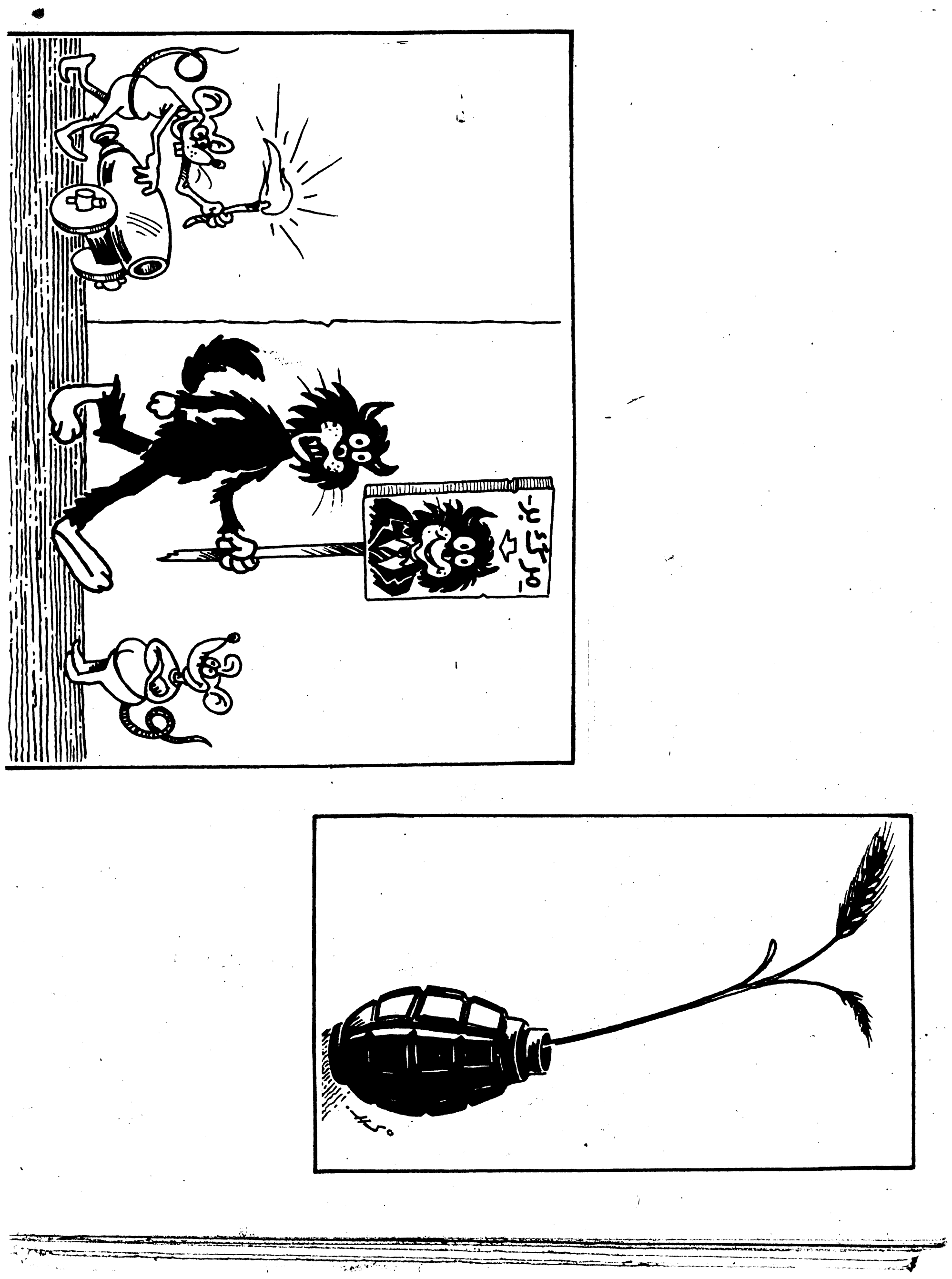


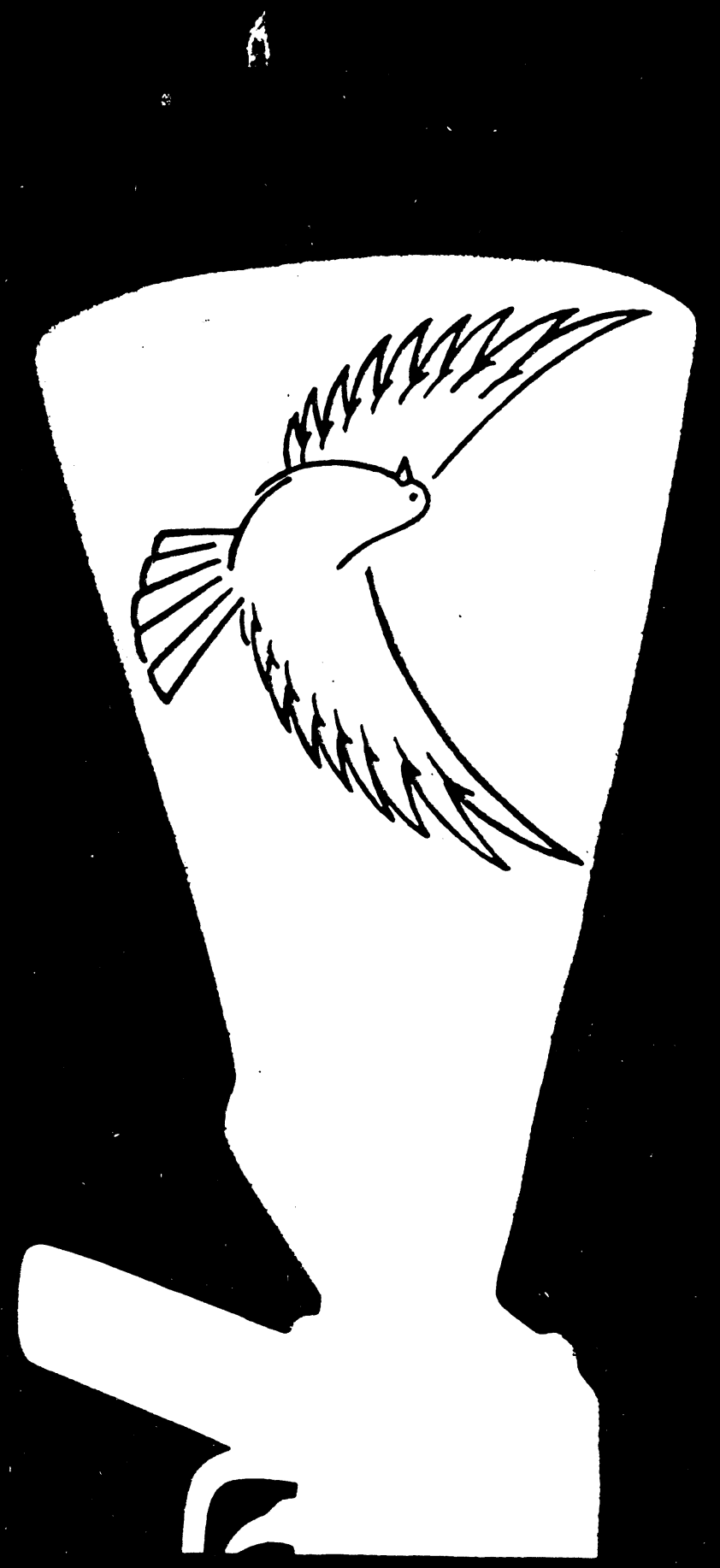




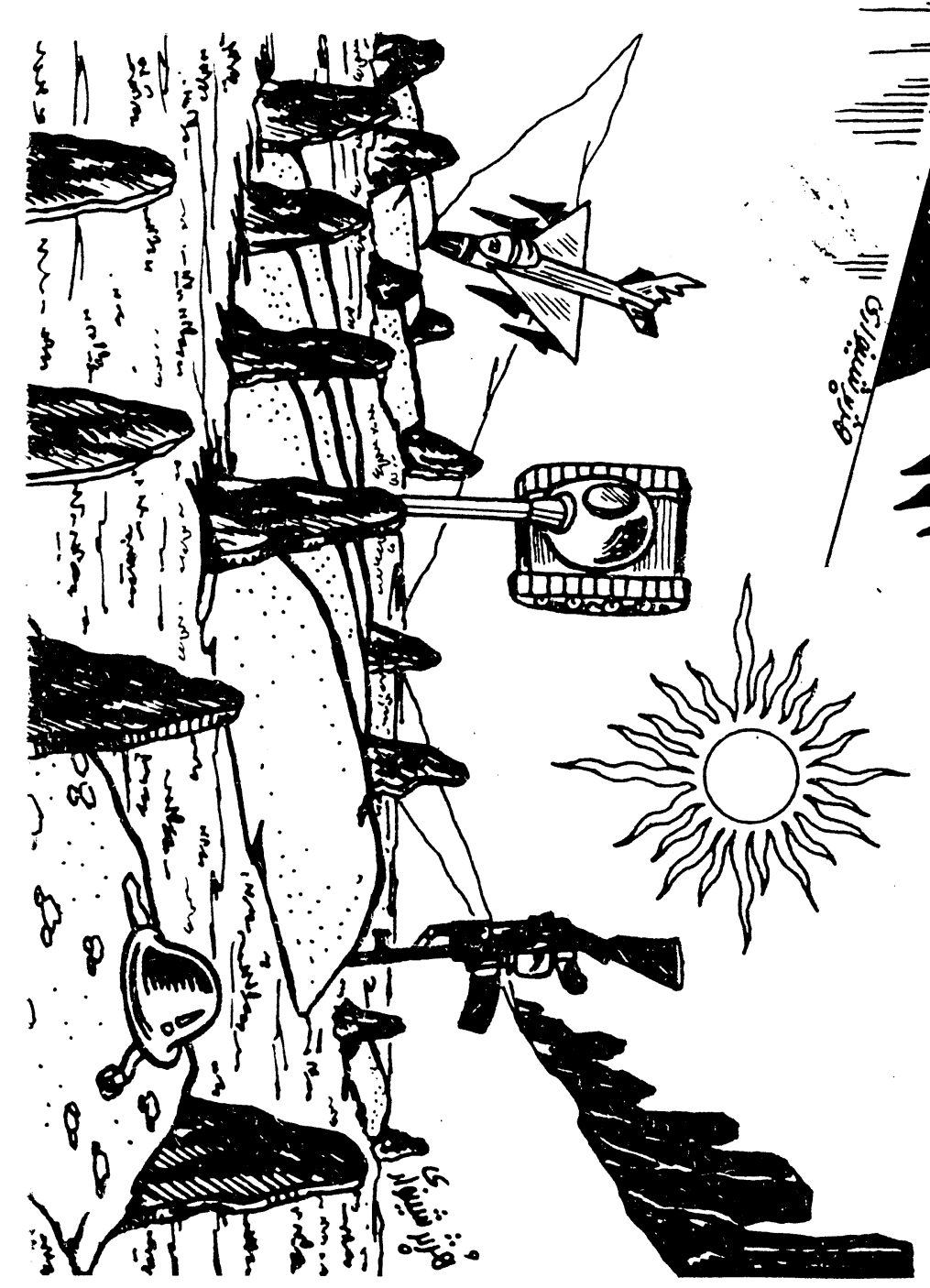




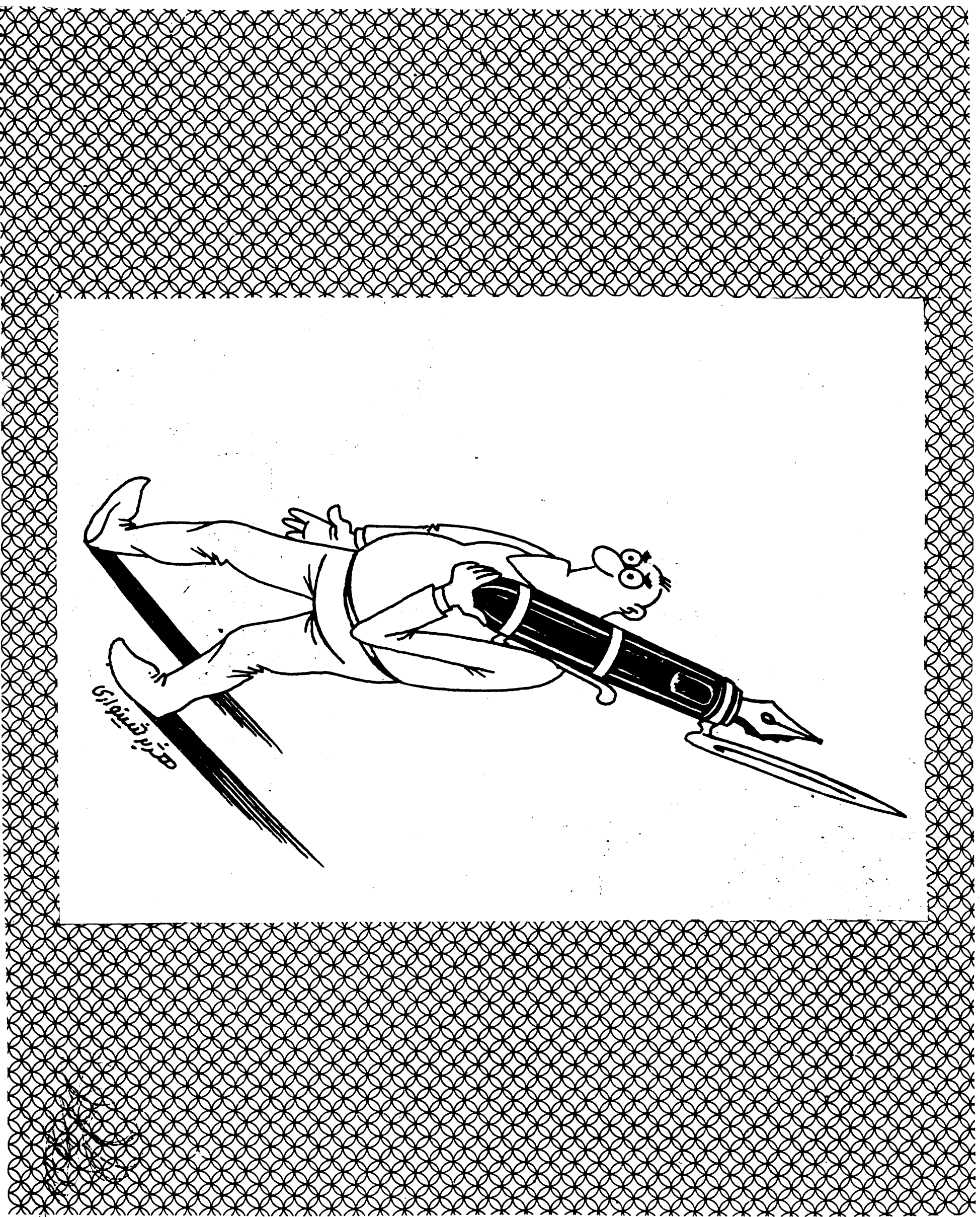

Hey 


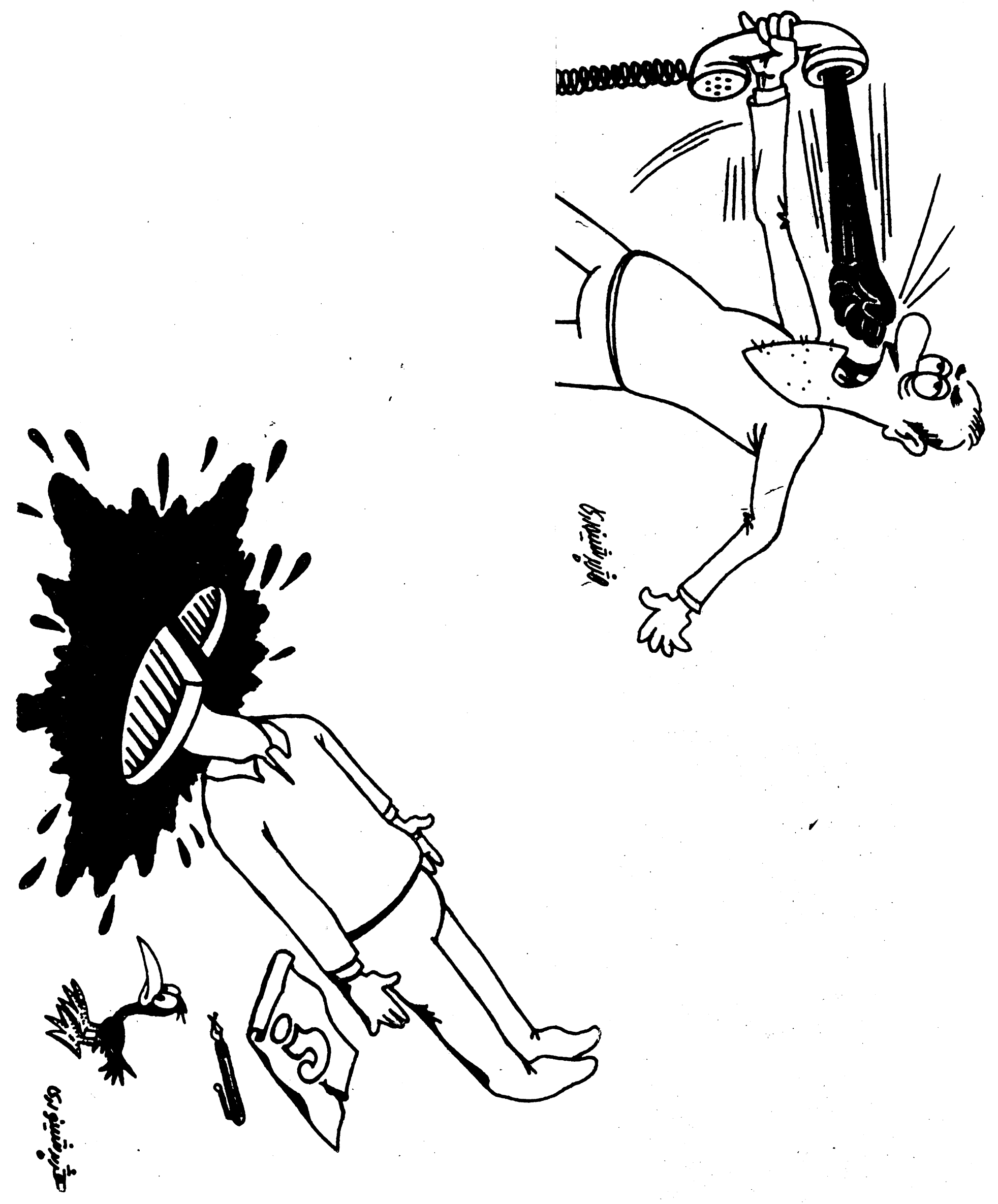



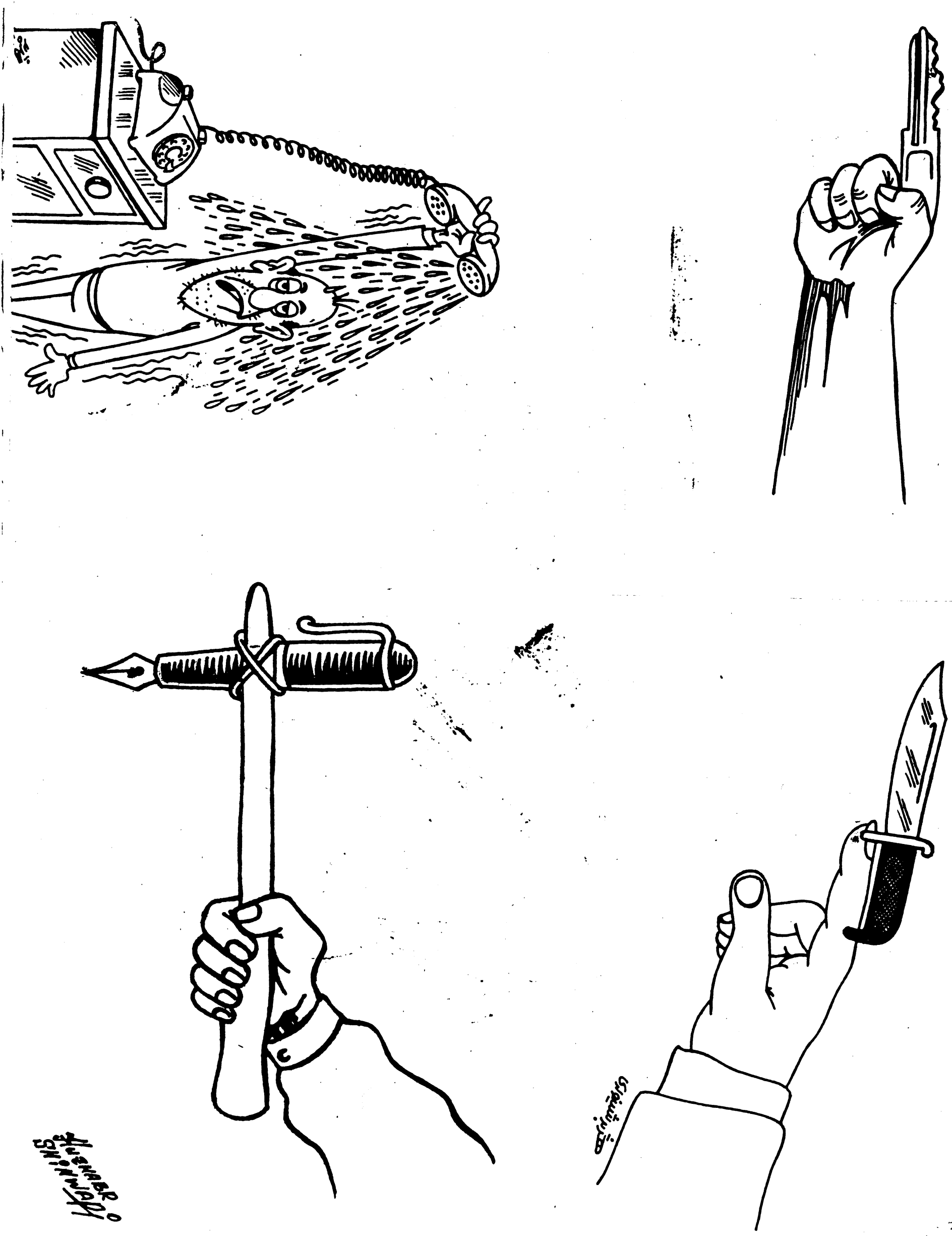



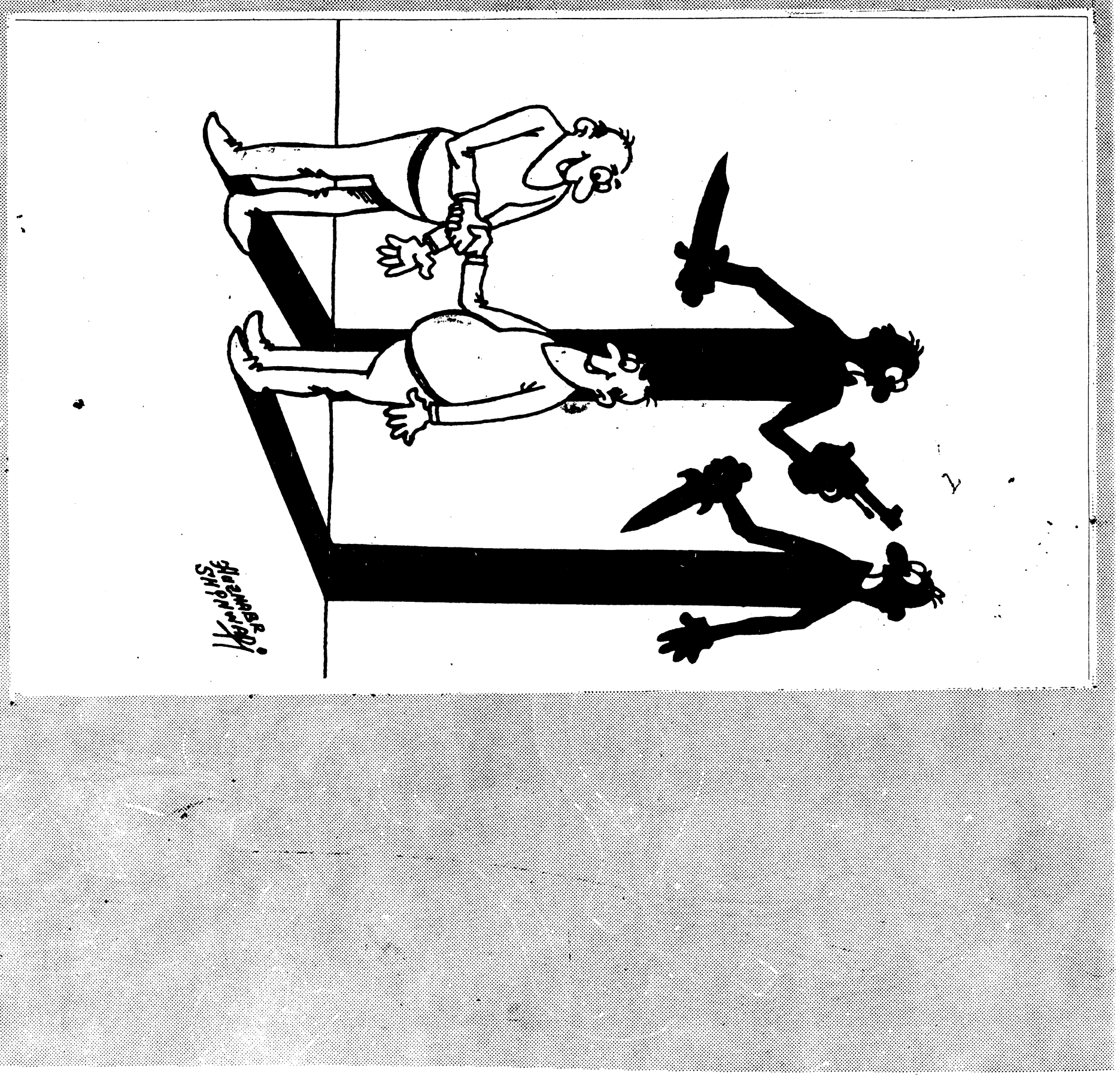



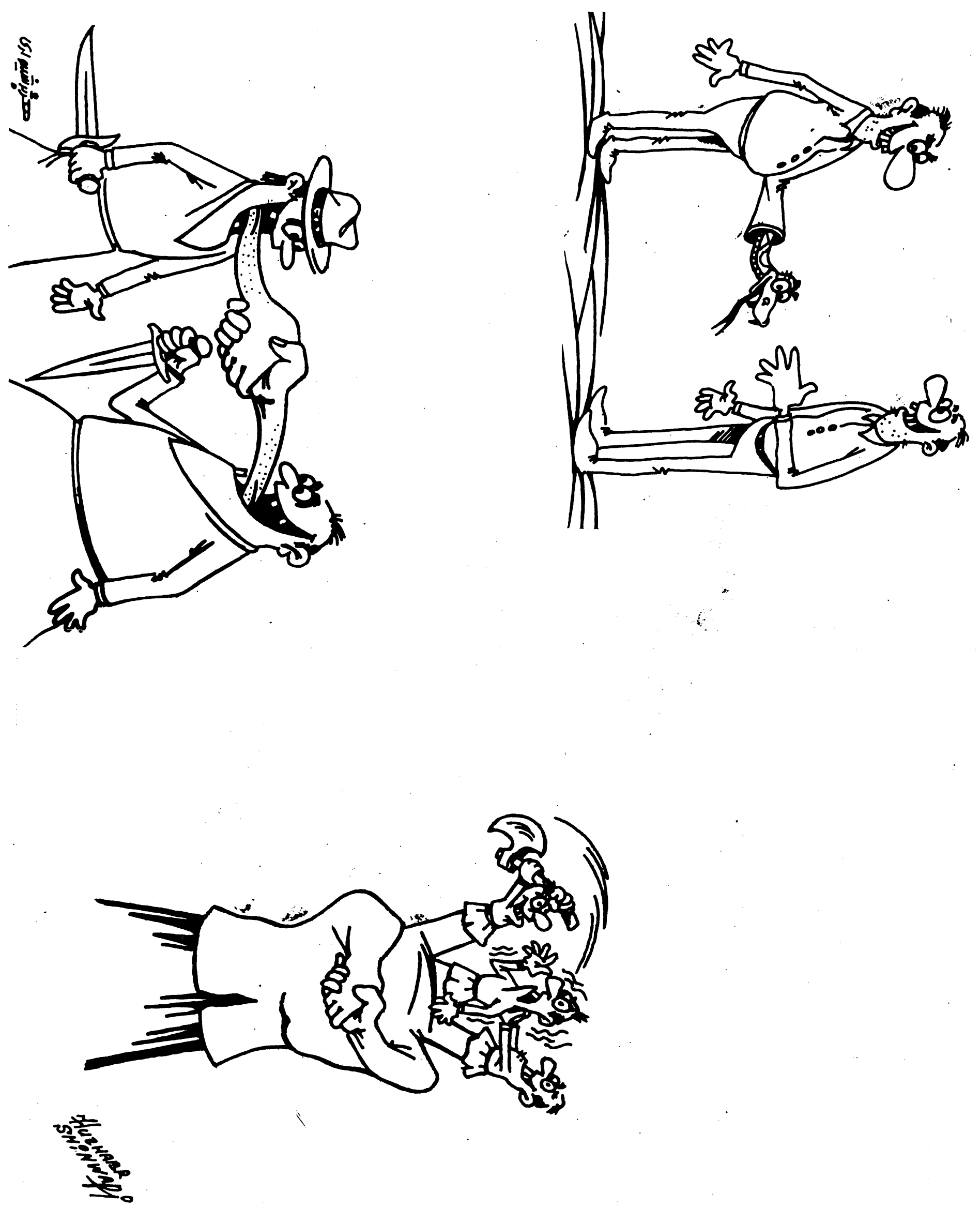


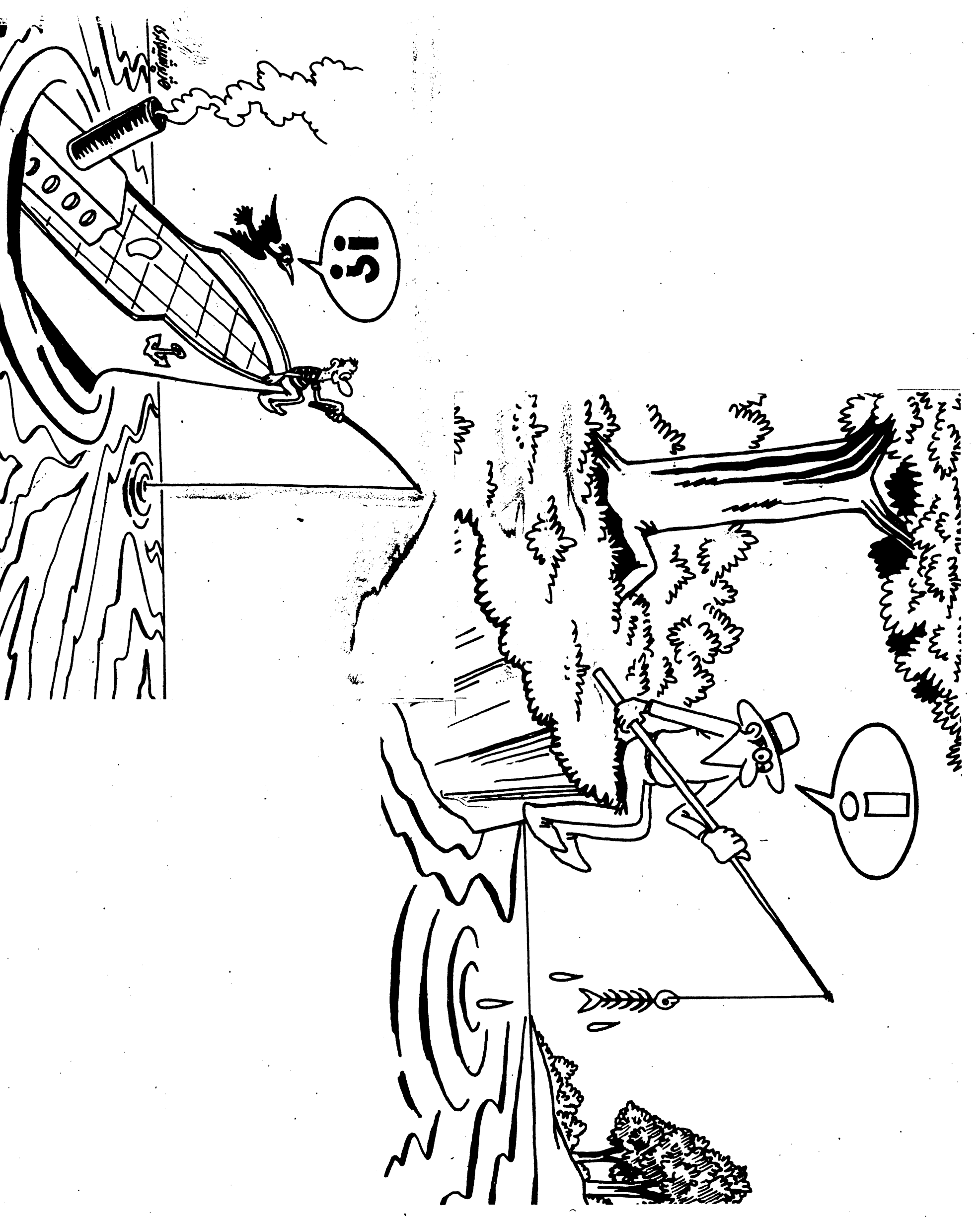




$$
\begin{aligned}
& \text { 等 }
\end{aligned}
$$

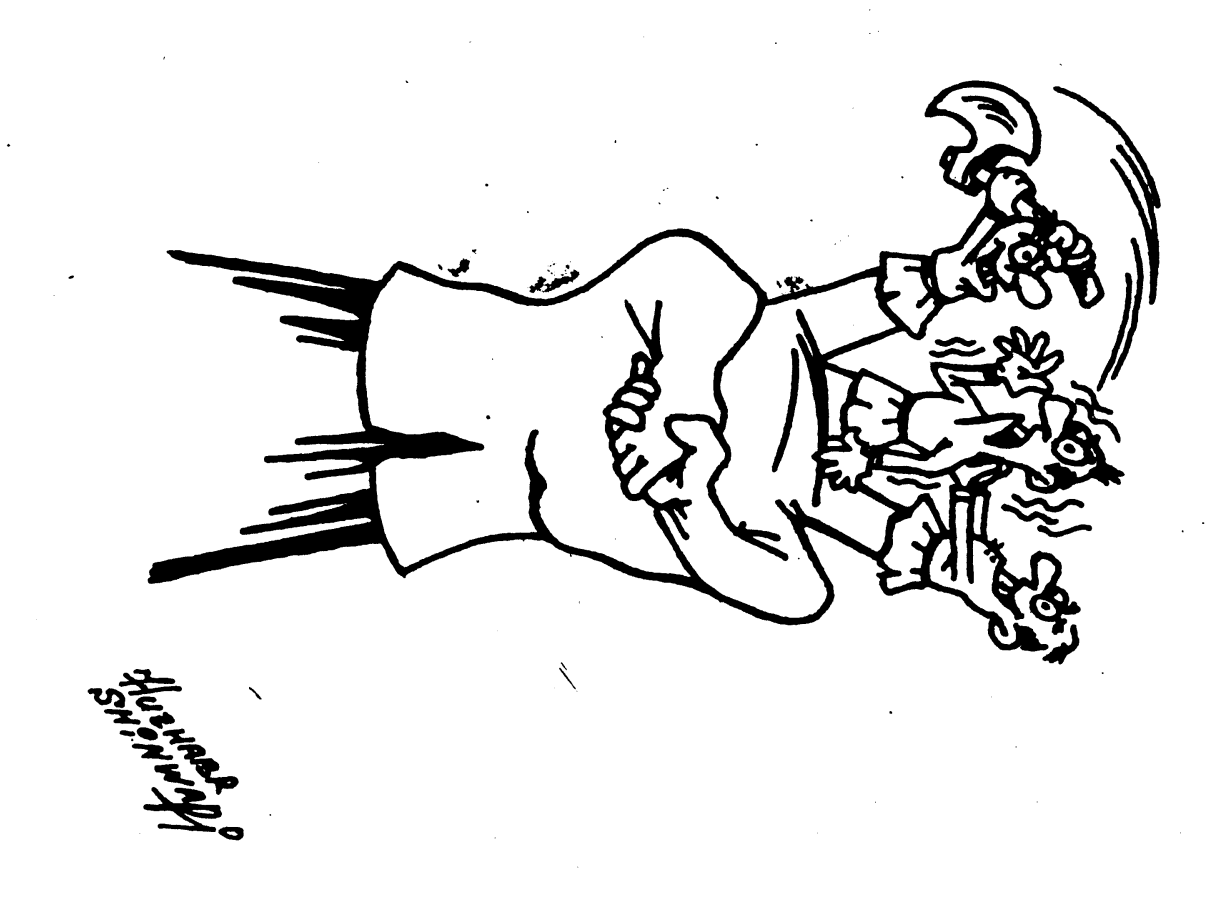



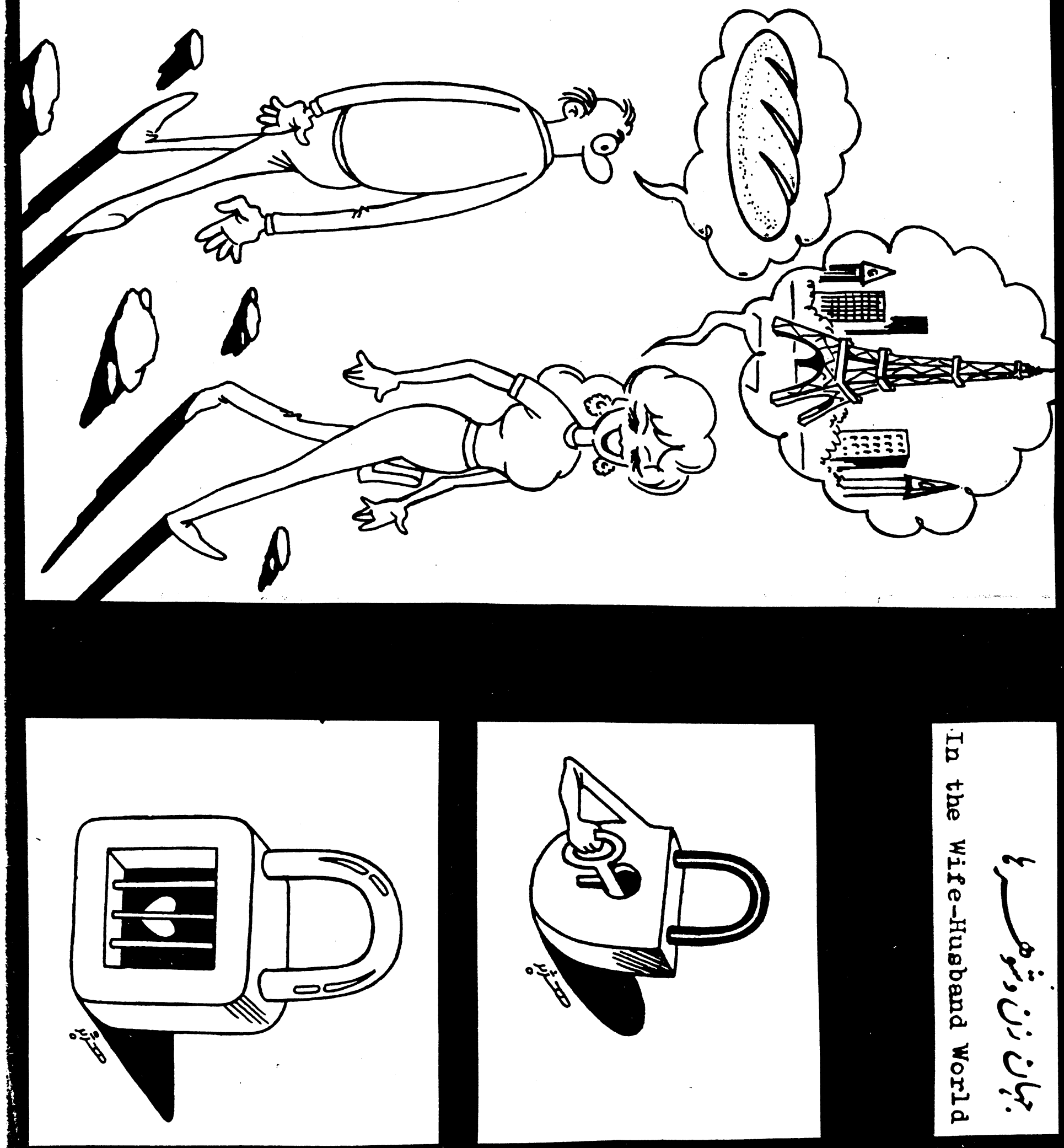

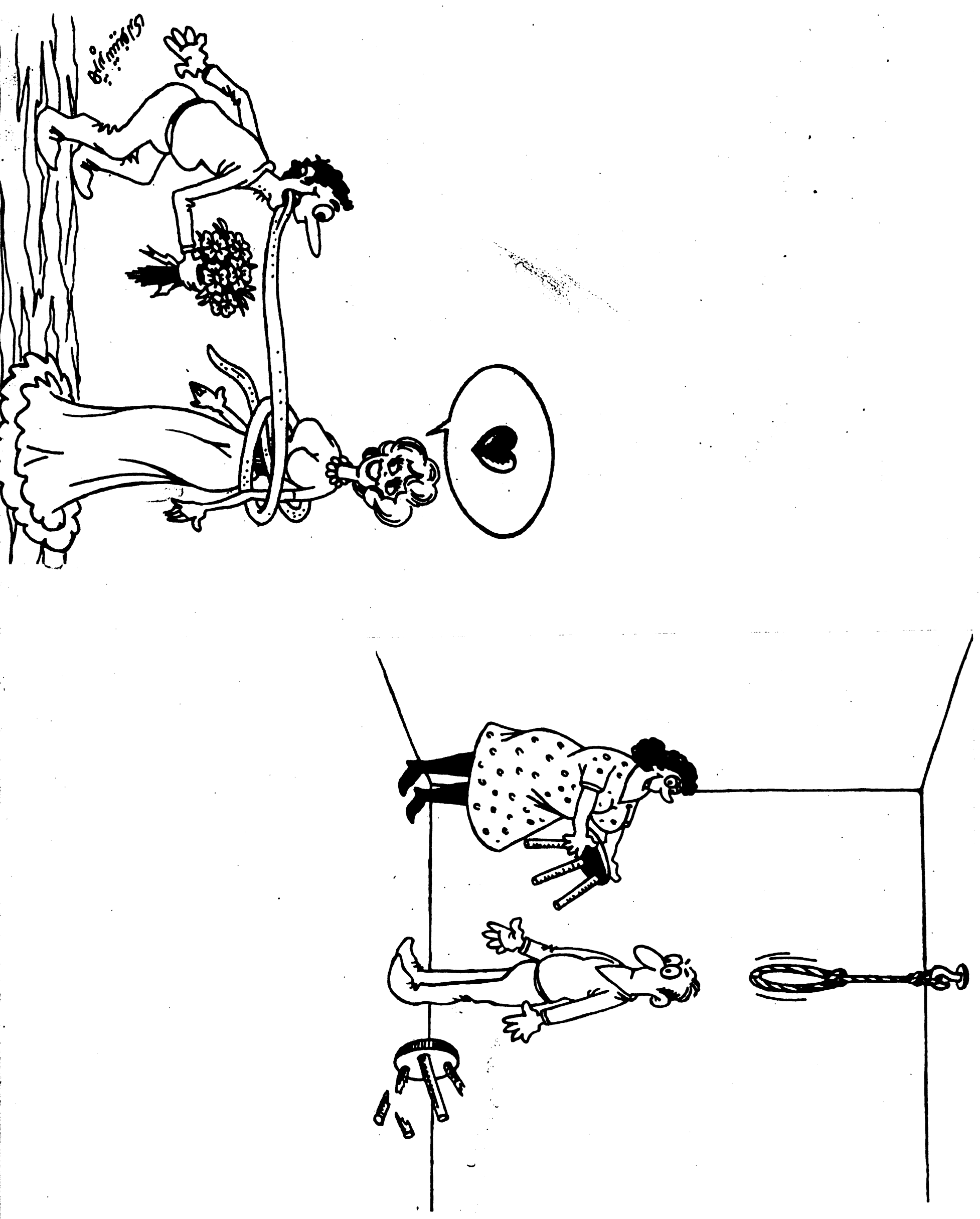

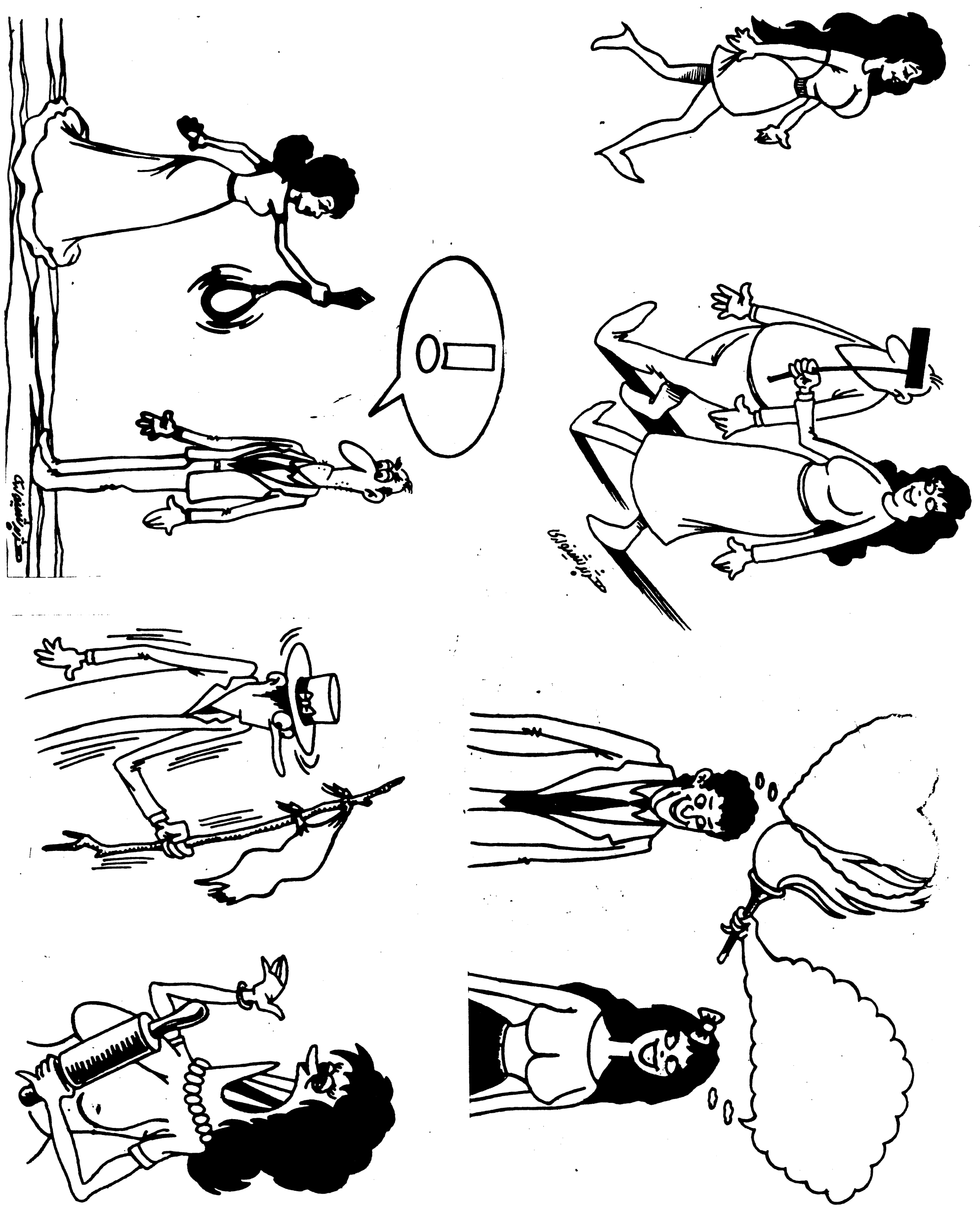


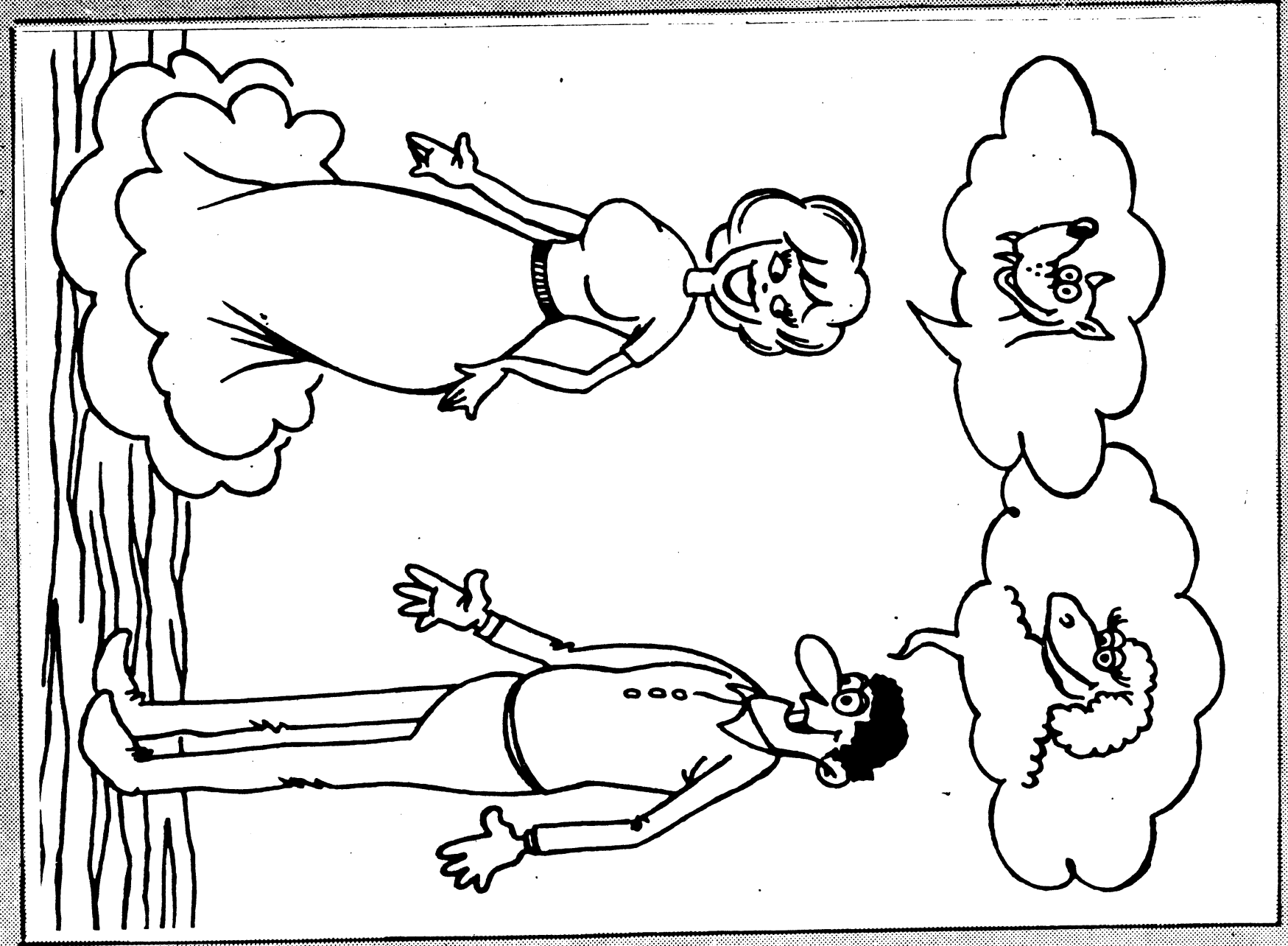




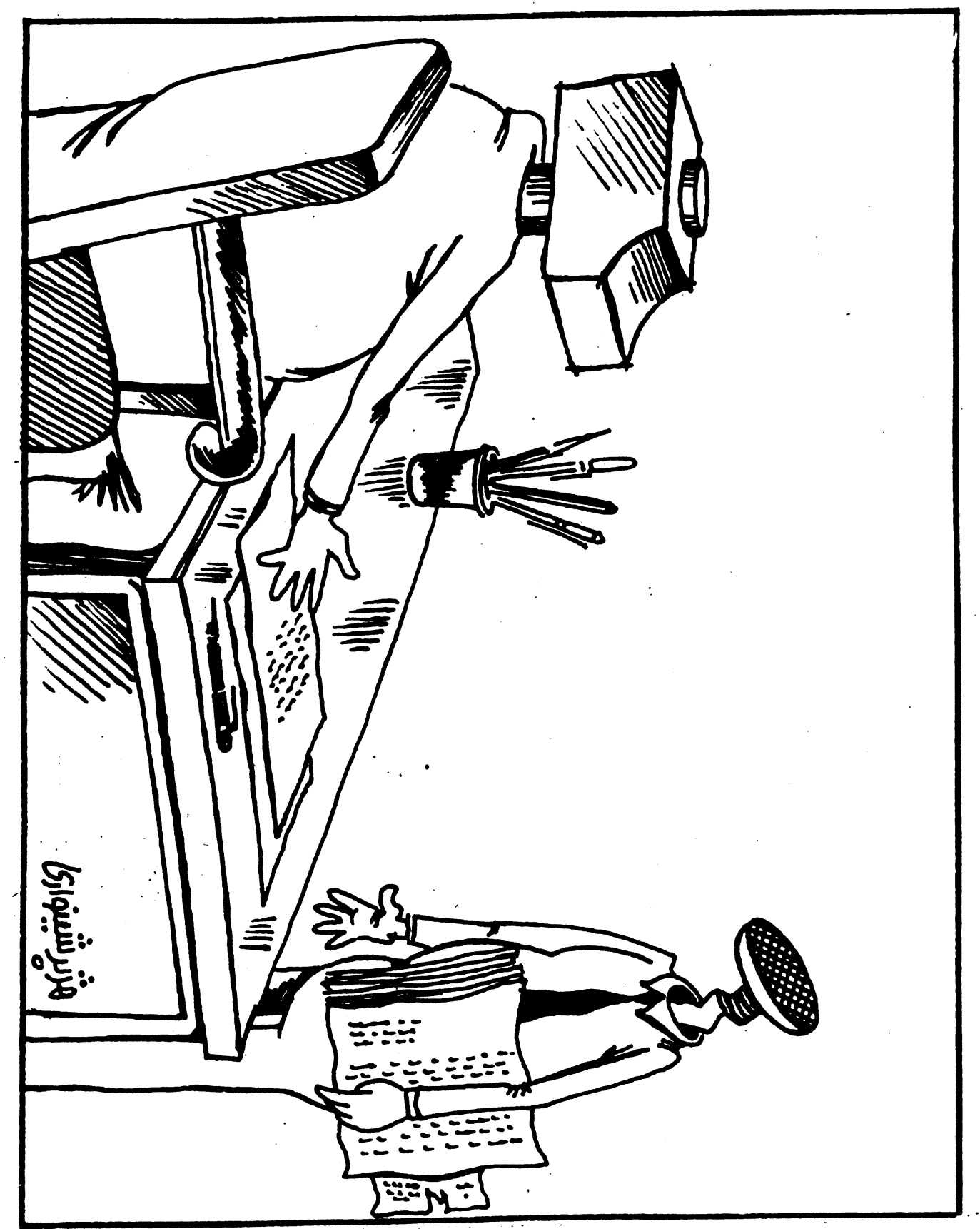



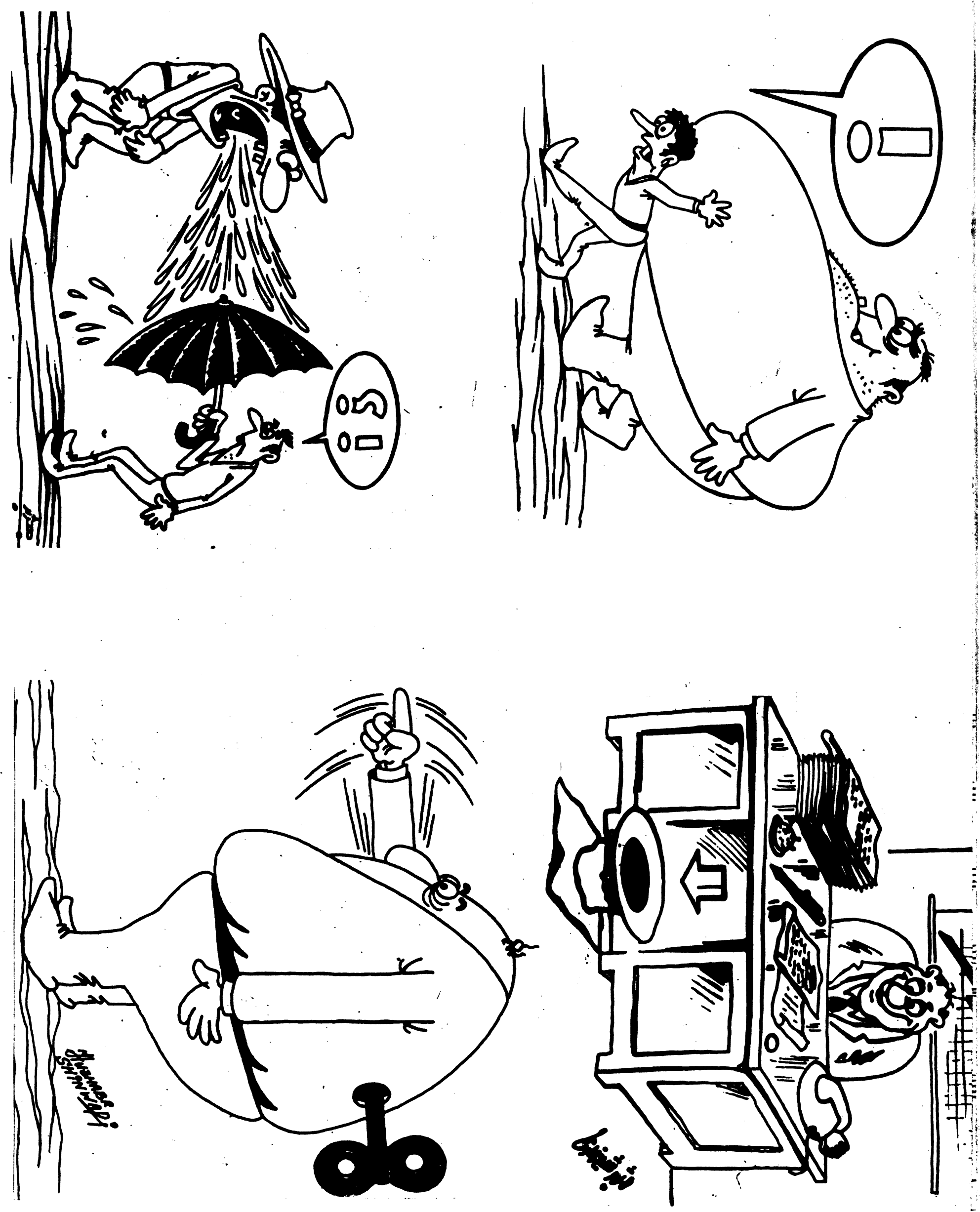

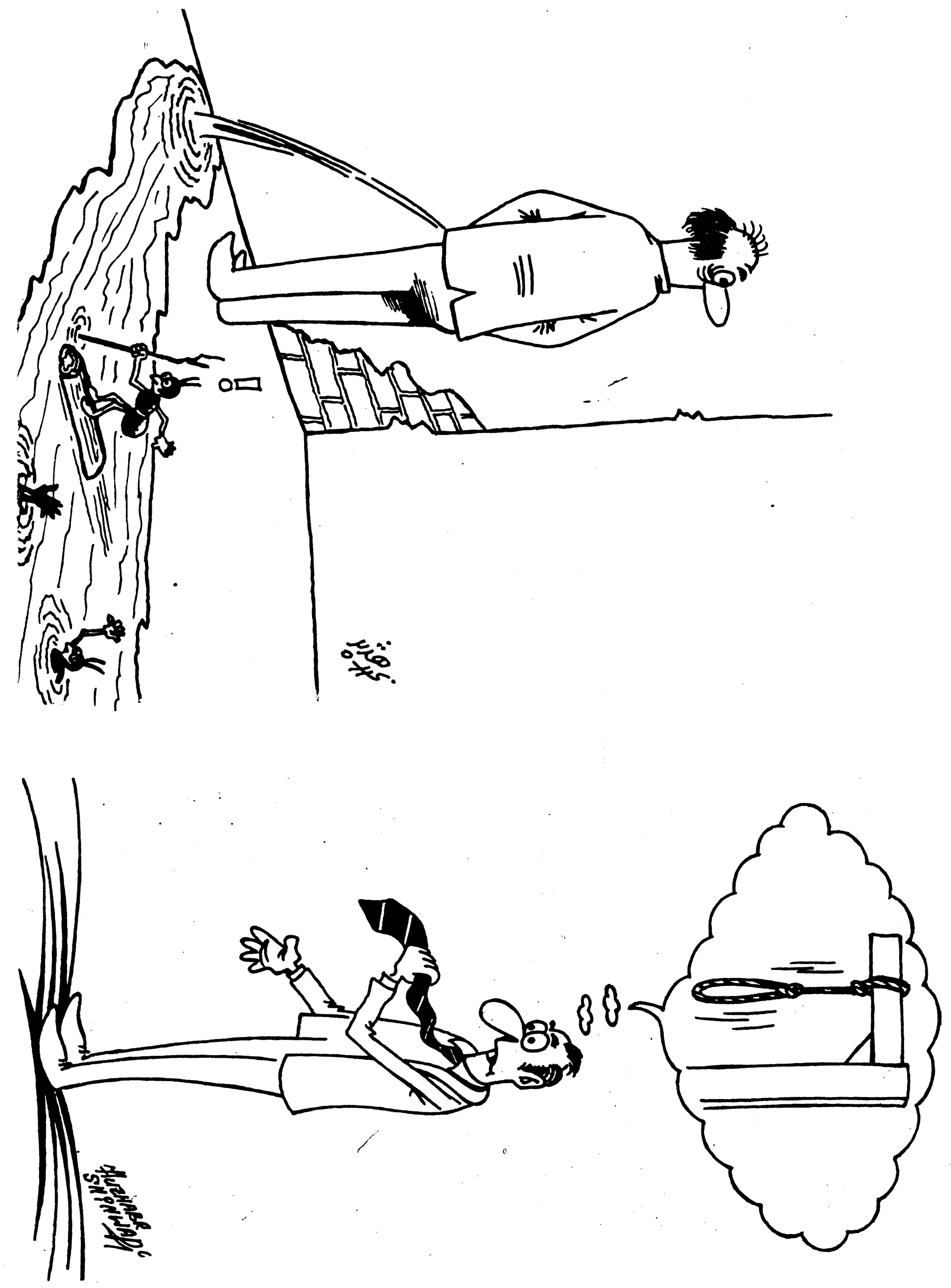


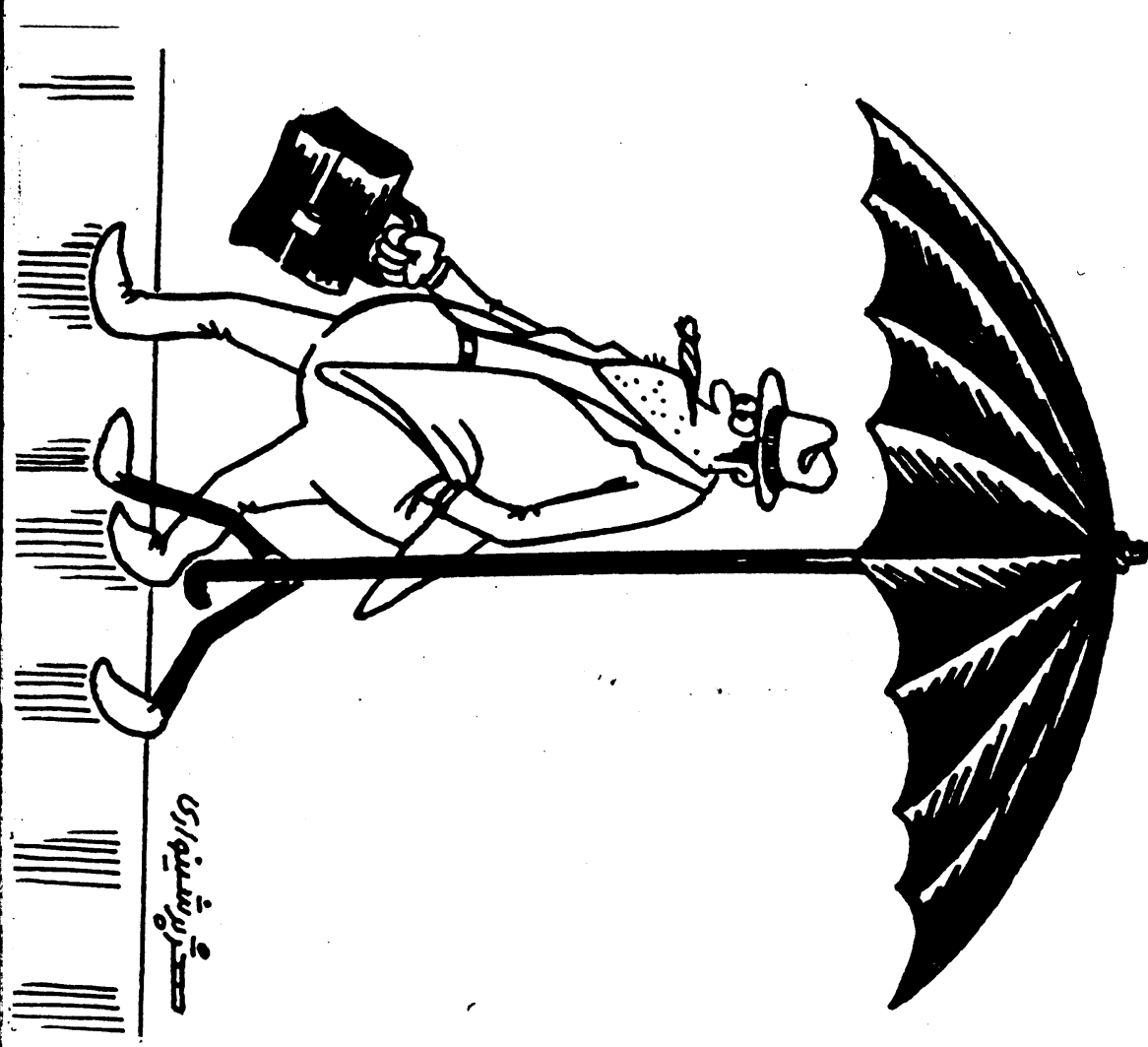

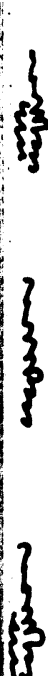

13.

130

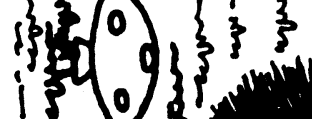

$\left\{\begin{array}{l}3 \\ 3 \\ 3\end{array}\right.$

\{ 3 s

1 \{\}$\}$

1
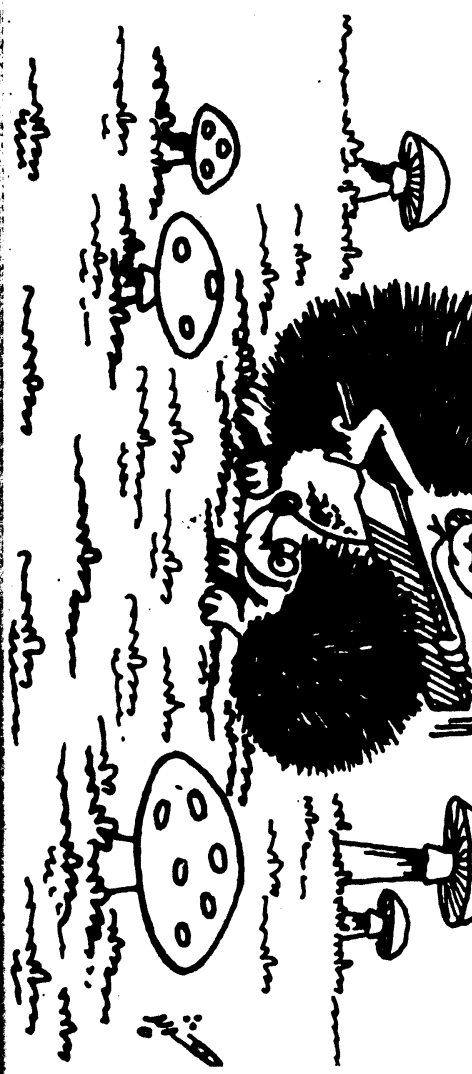

है।

I

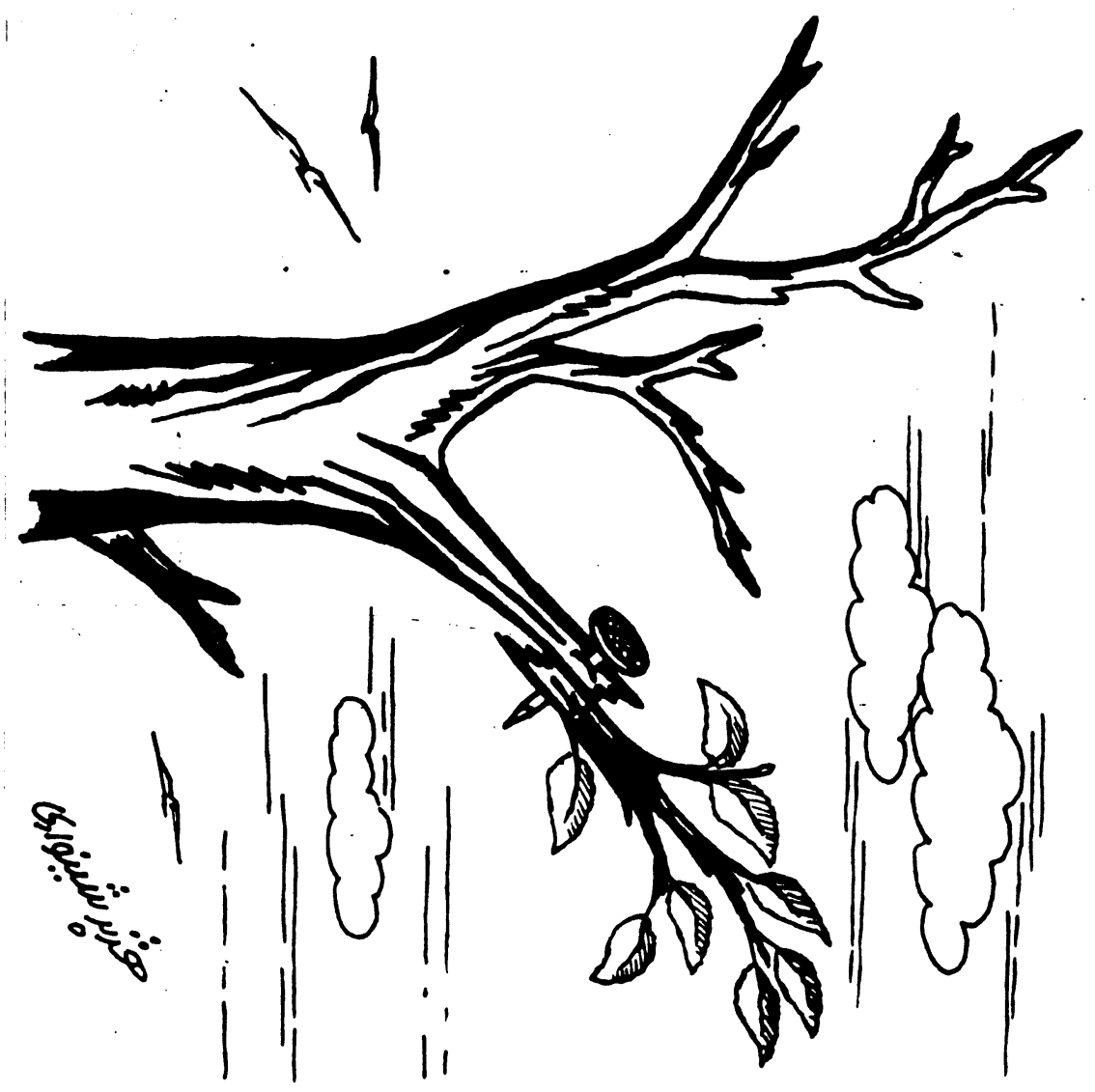



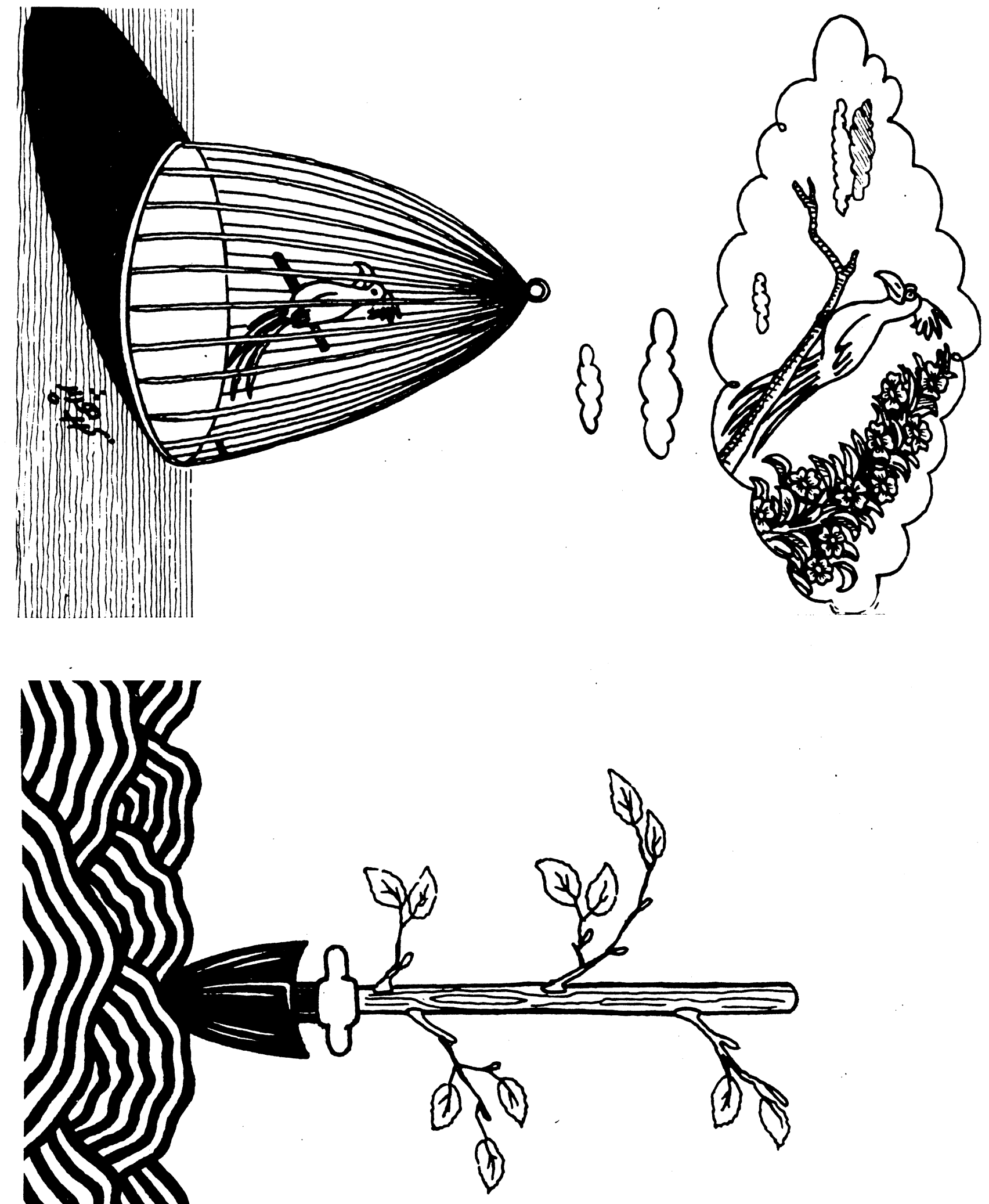

1) (1) 23$)$ 


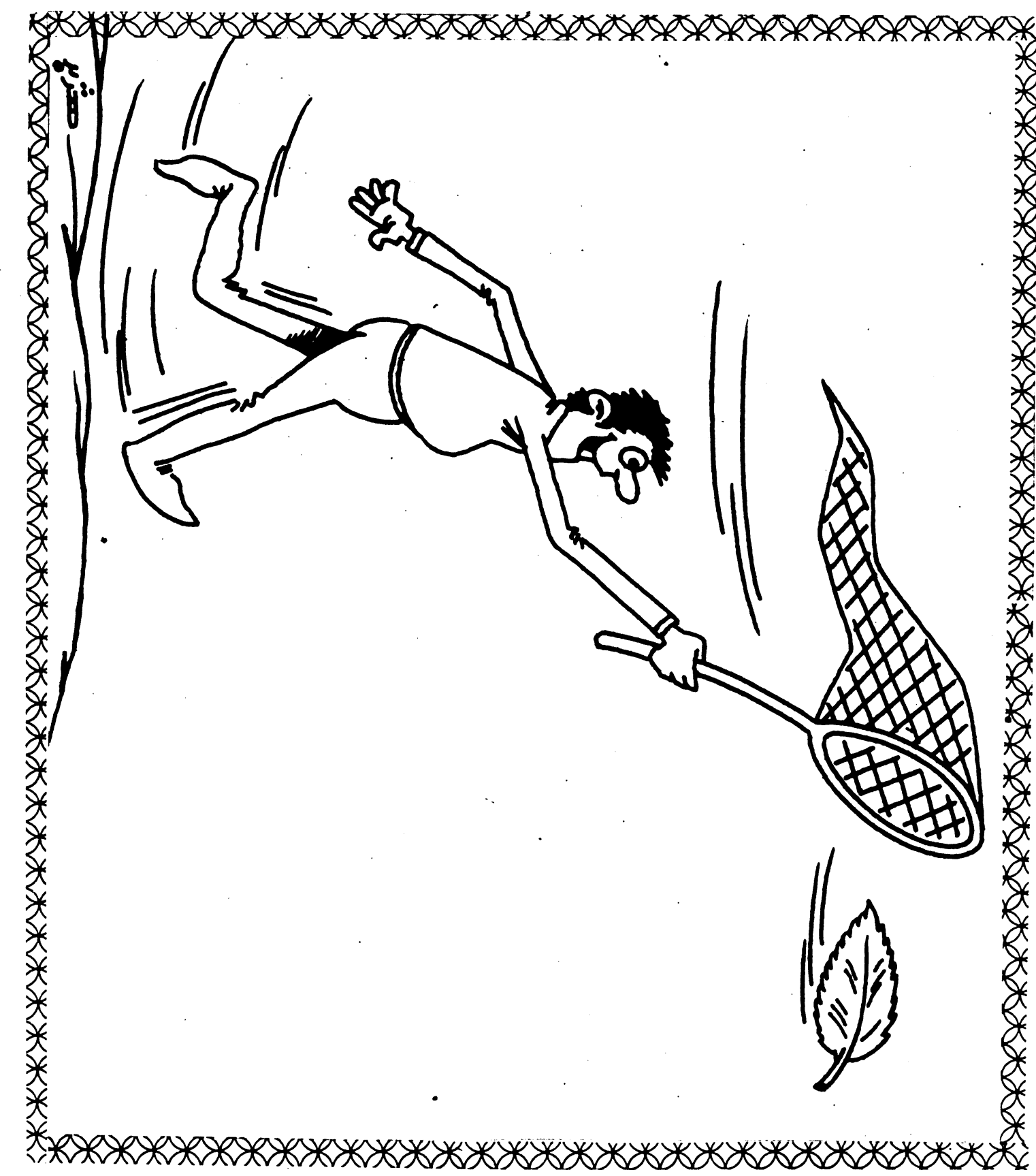

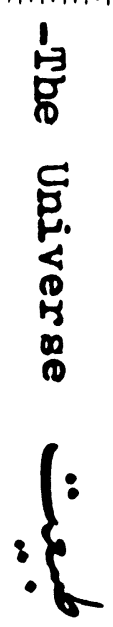




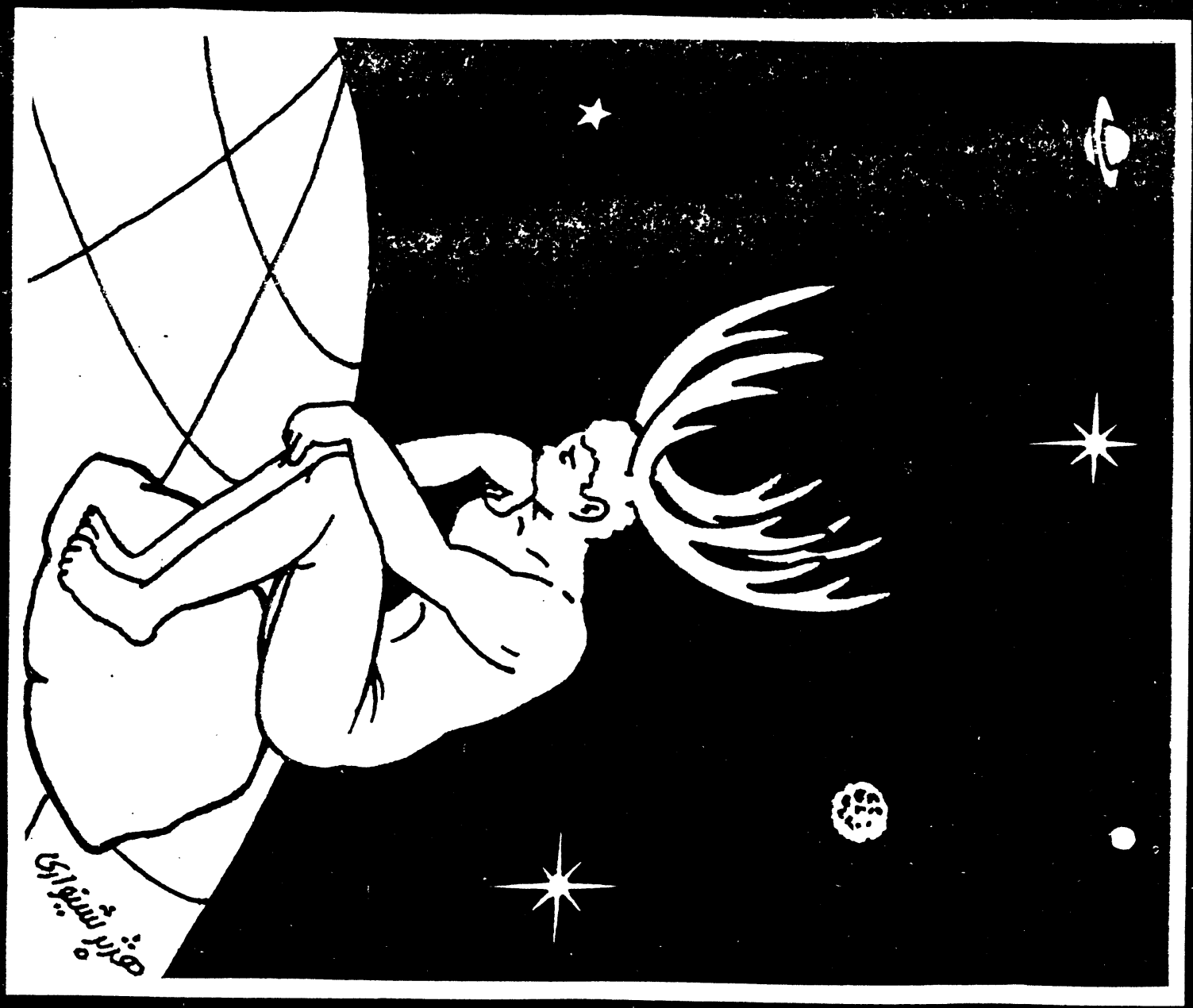



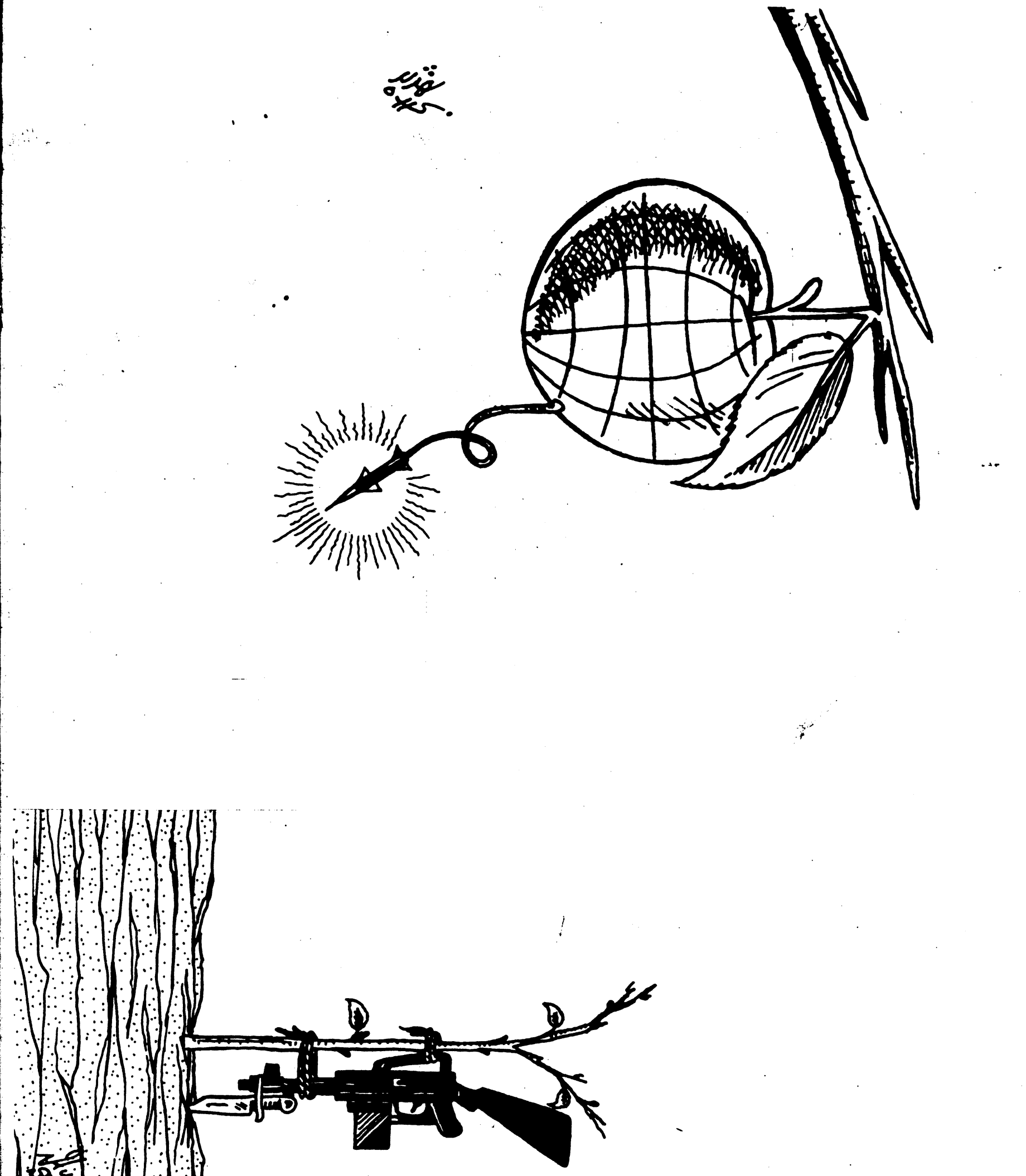

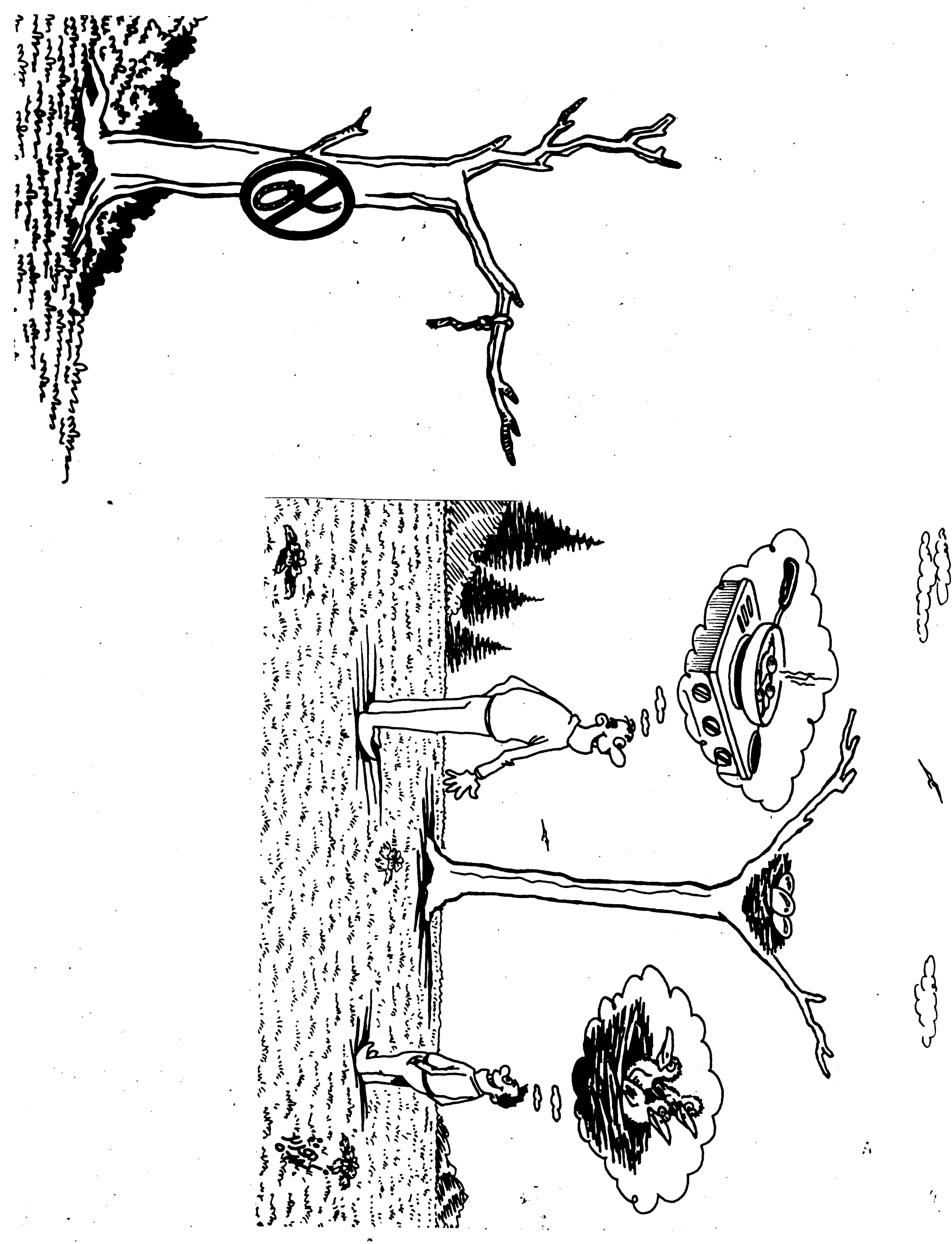

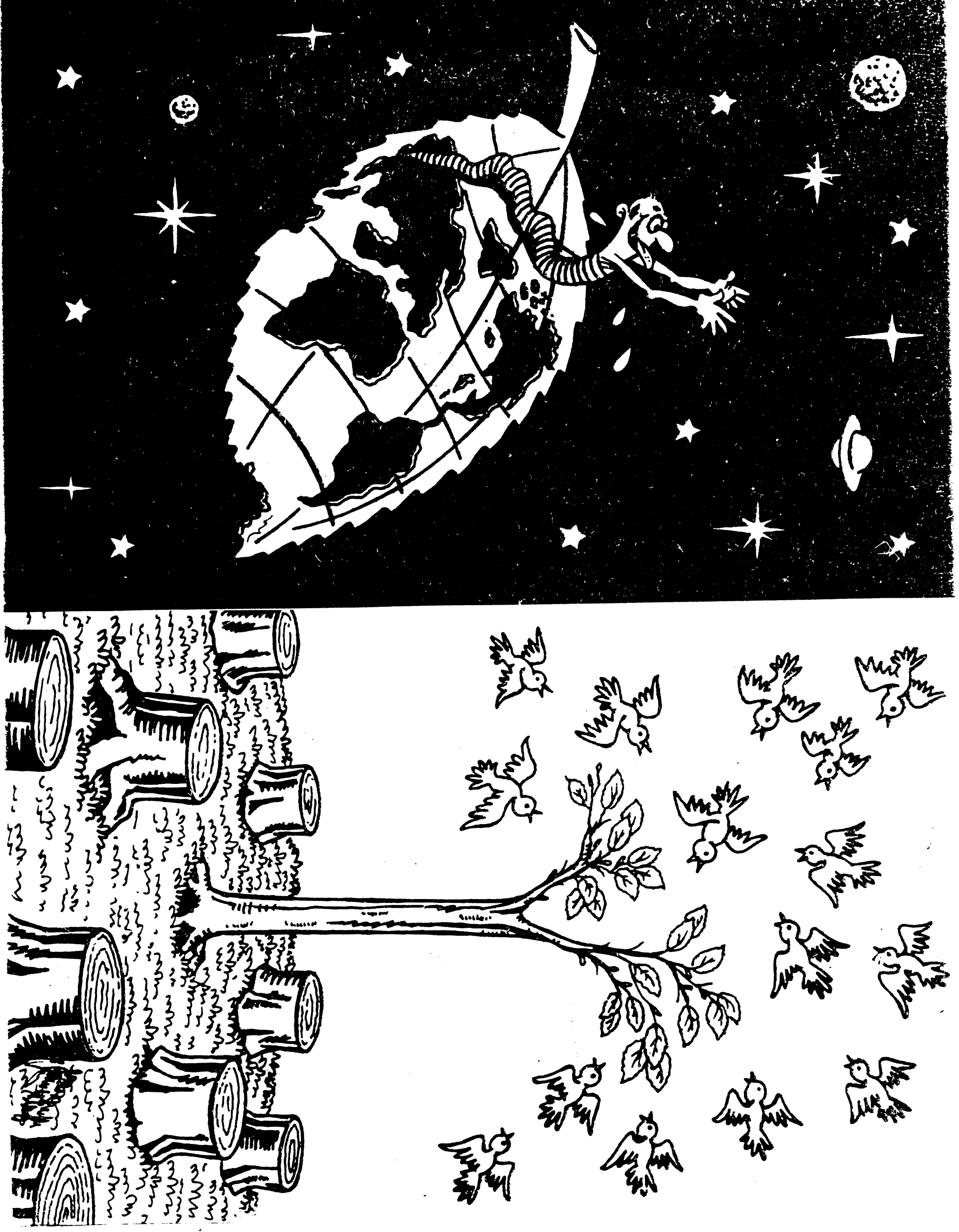

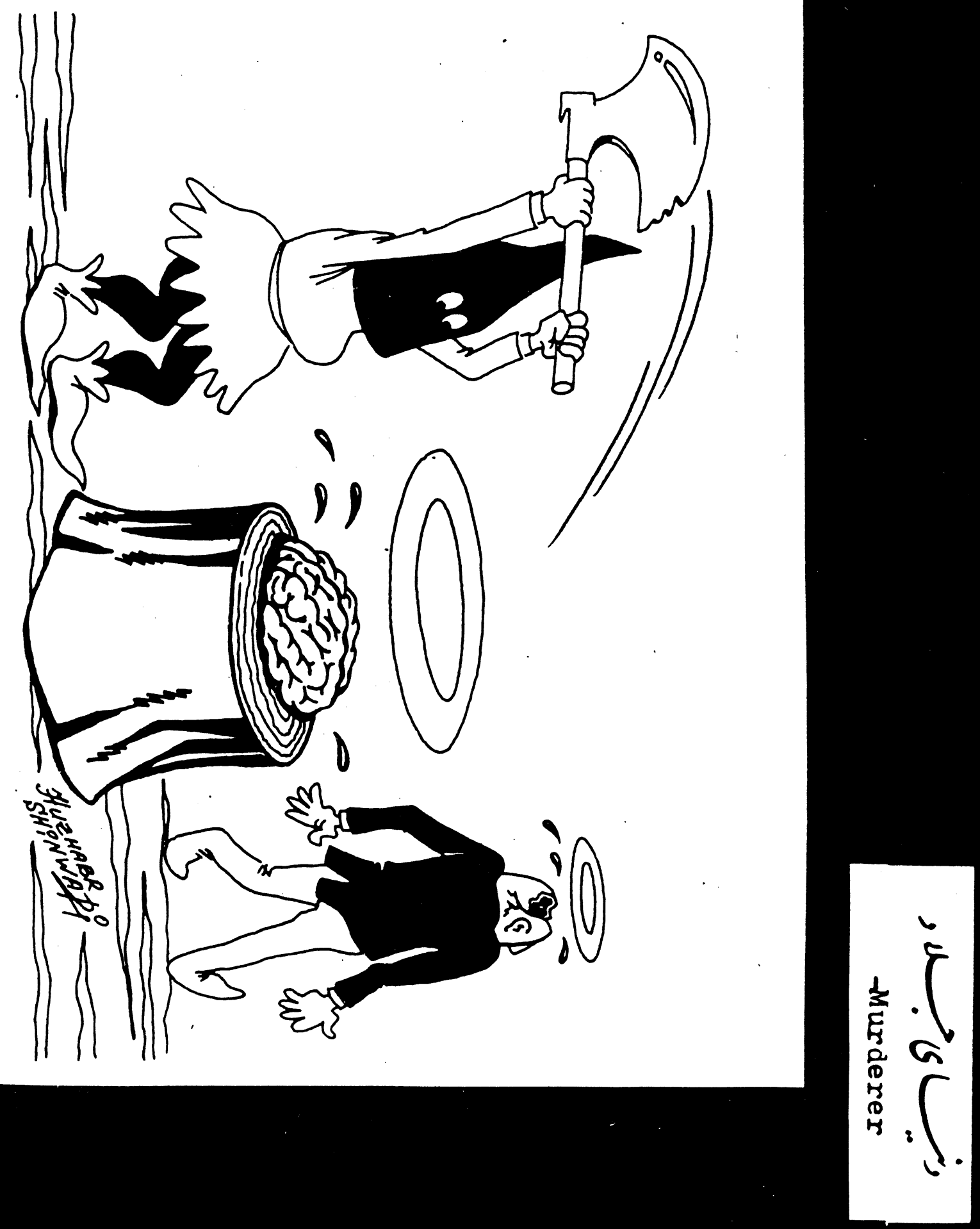


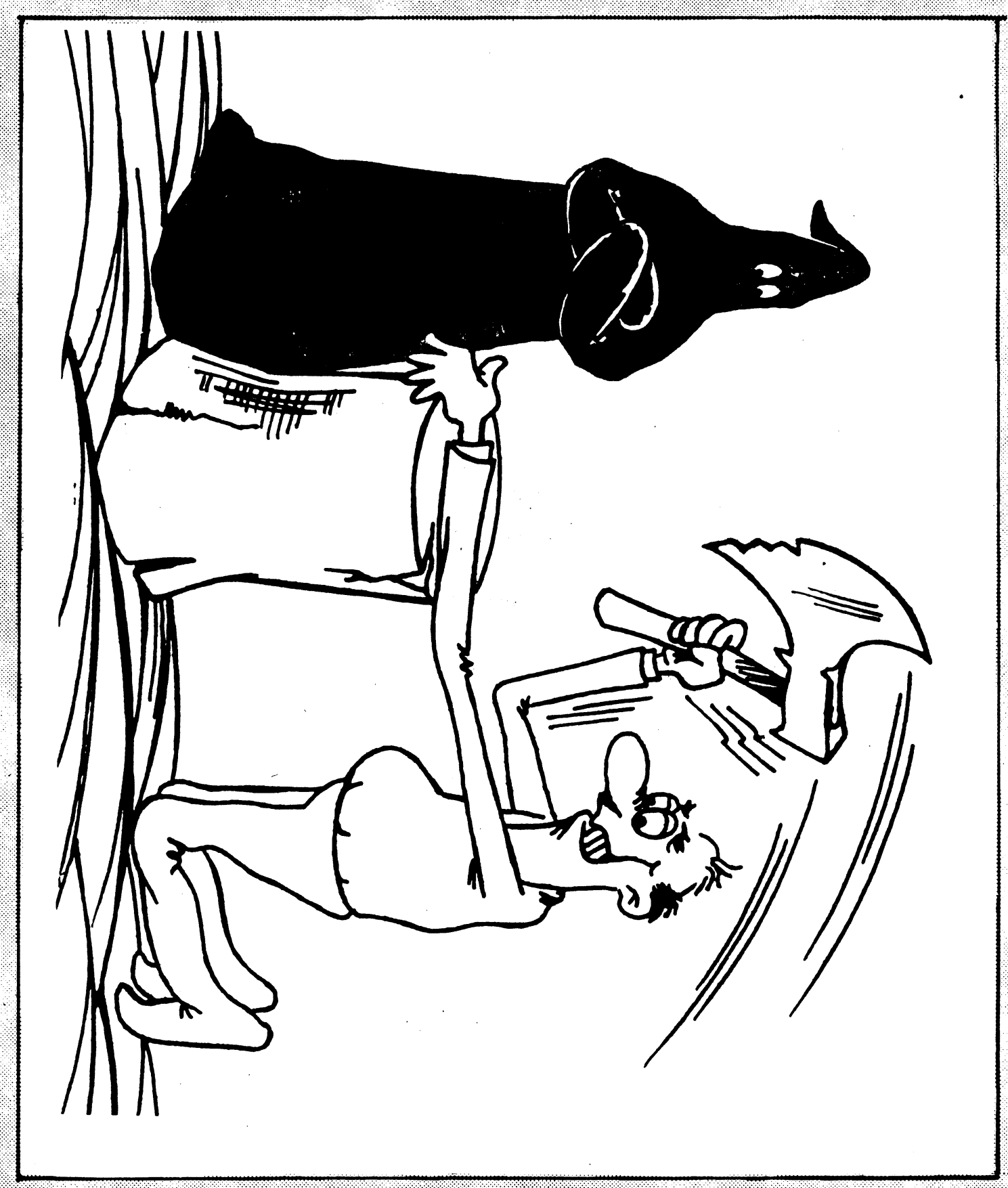




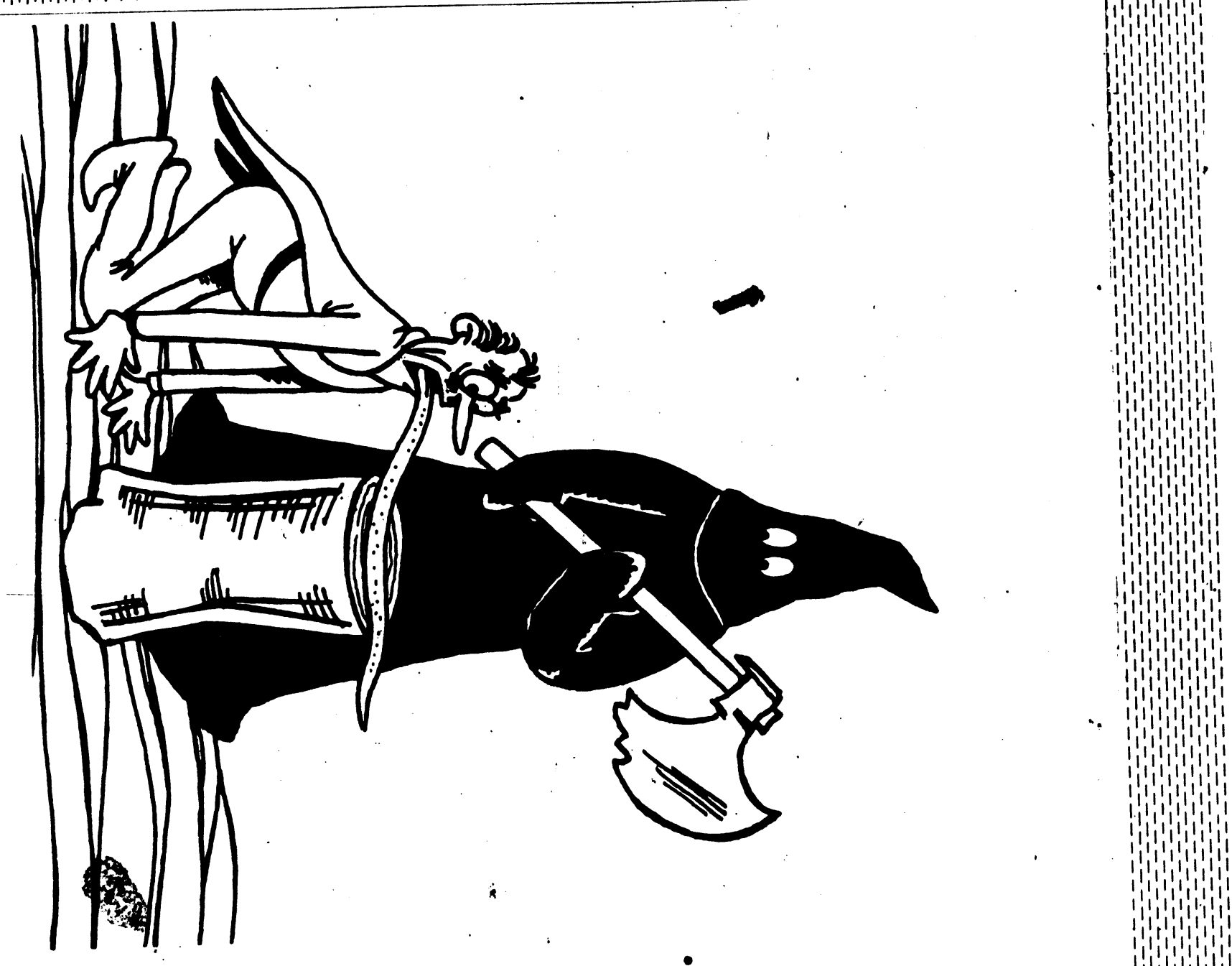




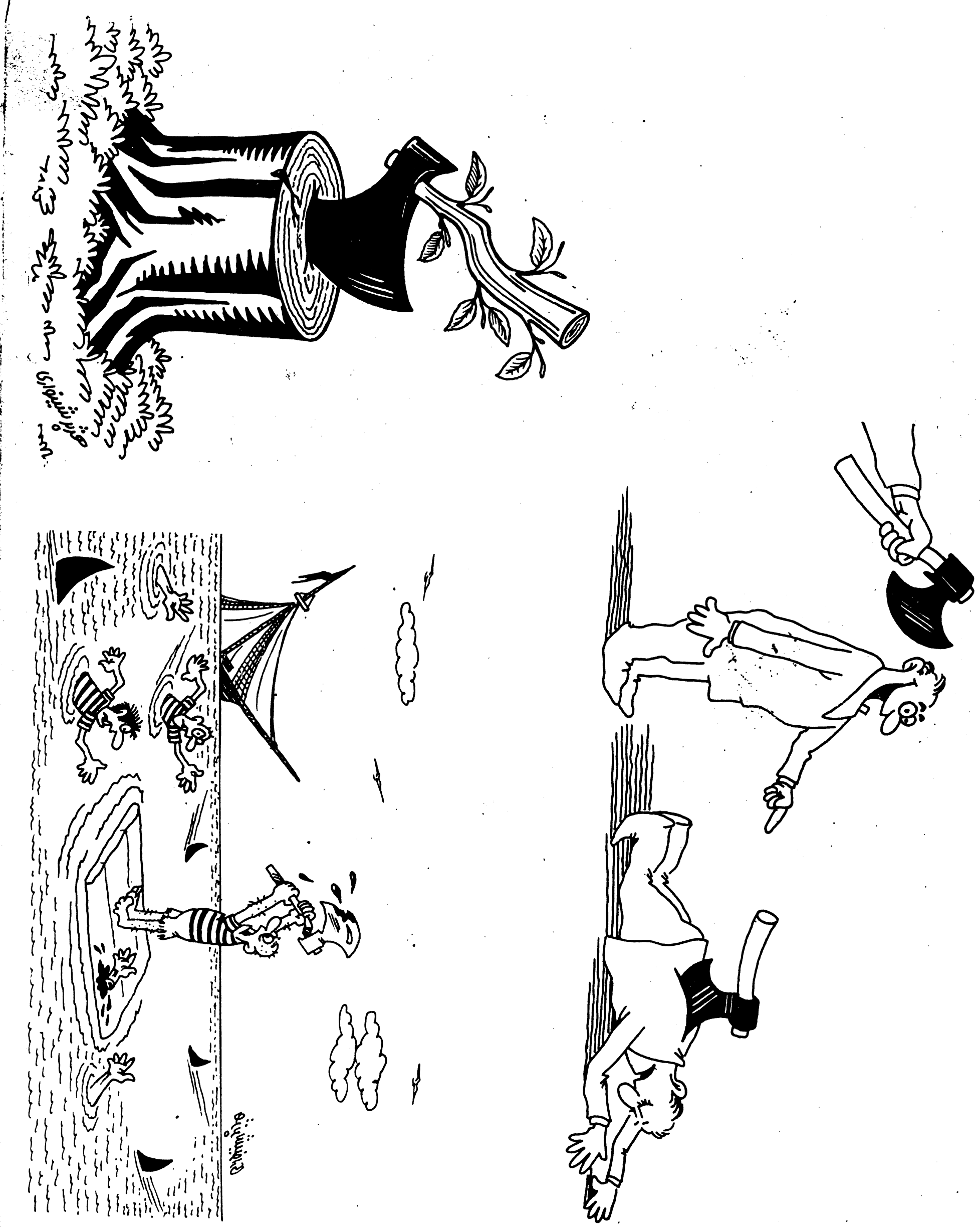



qeneral topograptur commications/reats Towns, cities, villages. 